\title{
الفكر المقاصدي وترسيخ الفكر العلمي
}

"إسماعيل الحسني

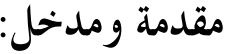

أحسب أن الاهتمام بدراسة الفكر المقاصدي من زاوية ما يرسخه من فكر علمي

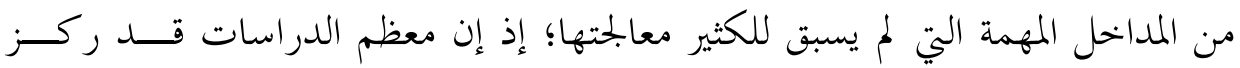

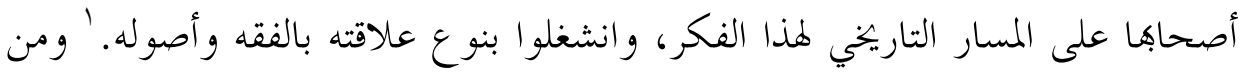

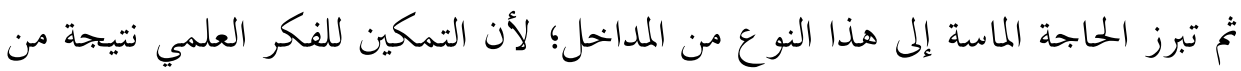
النتائج الأساسية التي يتوقف عليها كل إصلاح وتقدم منشود لأمتنا الإسلامية.

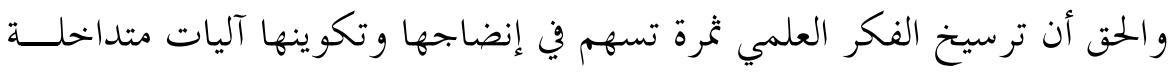

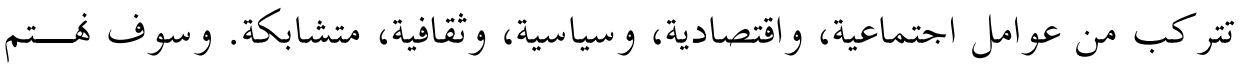

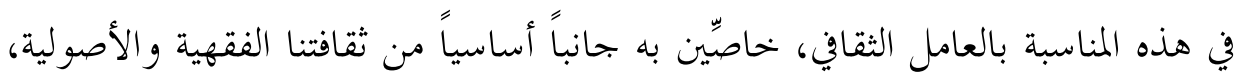

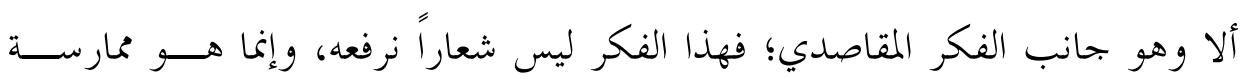

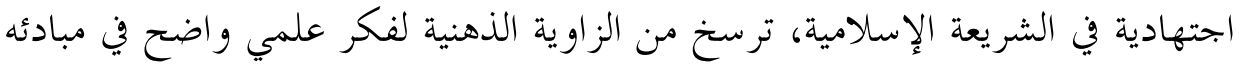
الأولية، وفي تقنياته البحثية، وفي مفاهيمه الإجرائية.

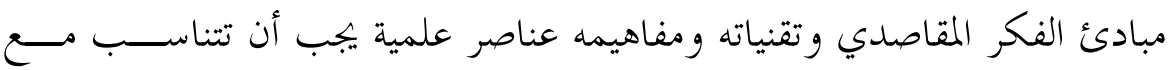

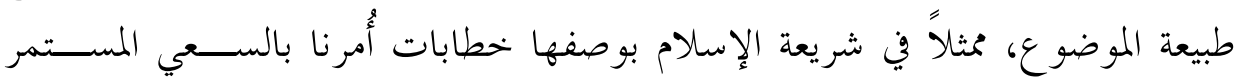

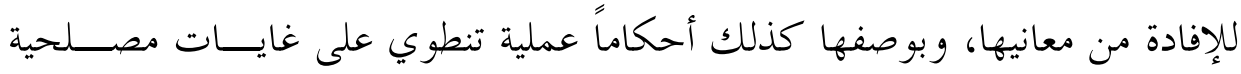

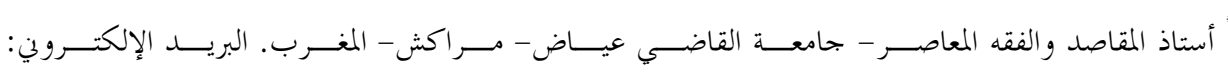
hacsani@maktoob.com

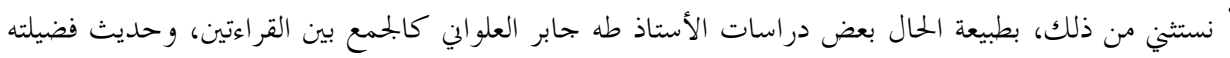

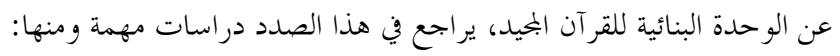

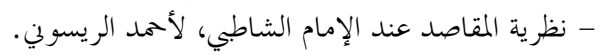

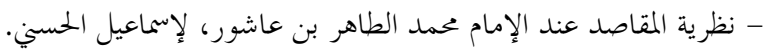
- السلطة العلمية في الإسلام، لعبد الجيد الصغير. 


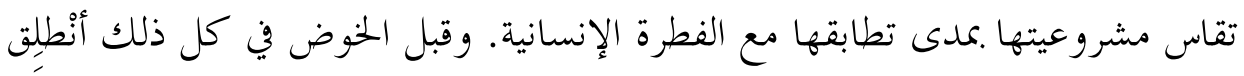

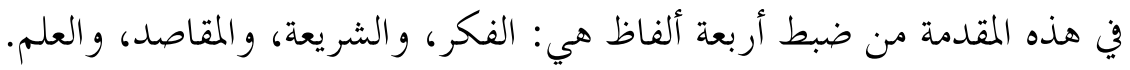

لم ترد مادة "ف.ك.ر" في القرآن الكريم بصيغة الاسم أو المصدر، ولا توجد فيـــهـ

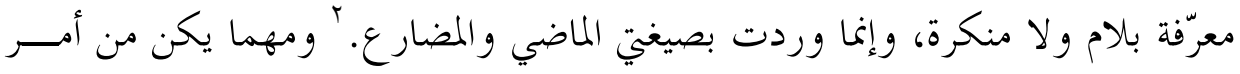

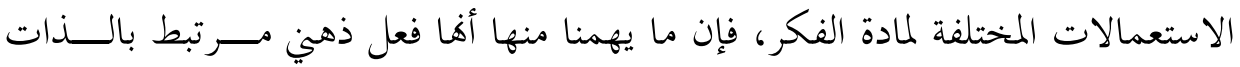

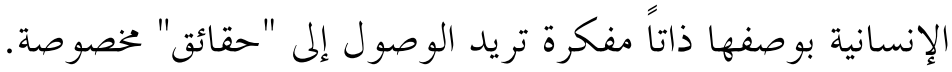

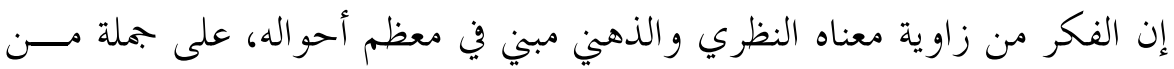

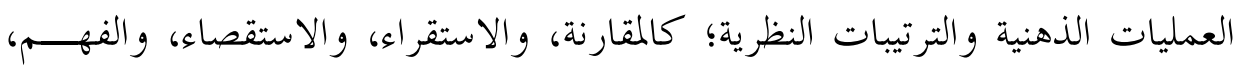

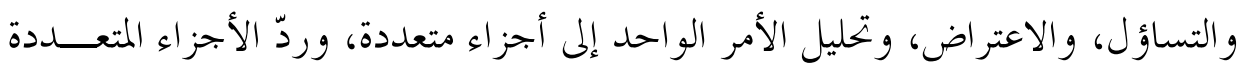

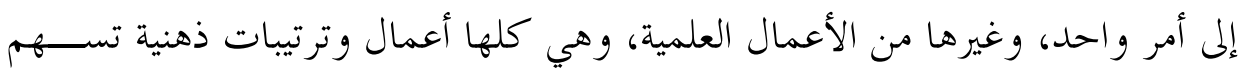

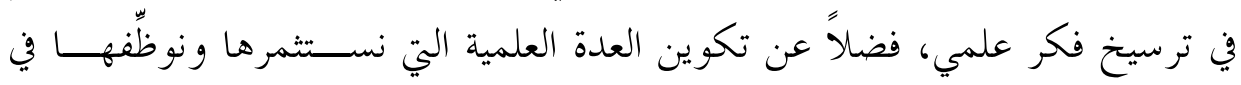
التوصل إلى المقاصد الشرعية.

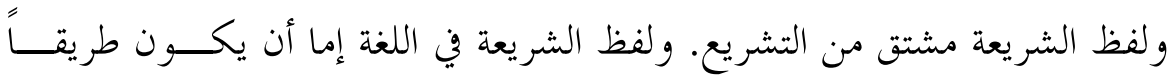

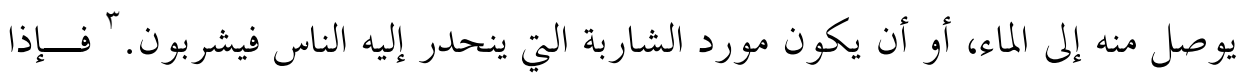

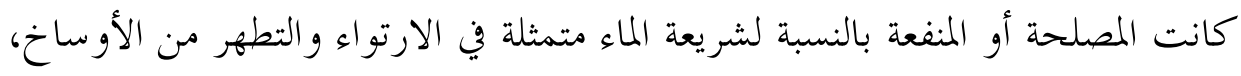

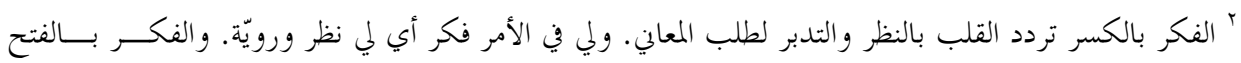

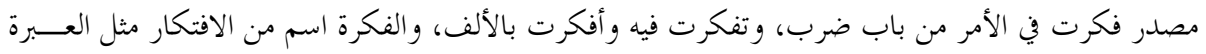

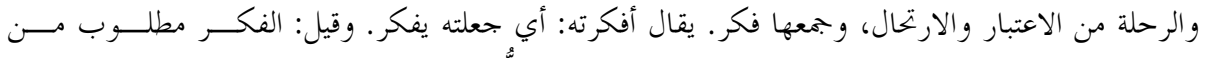

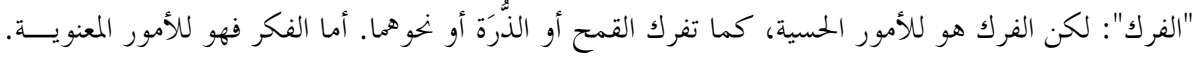

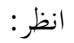

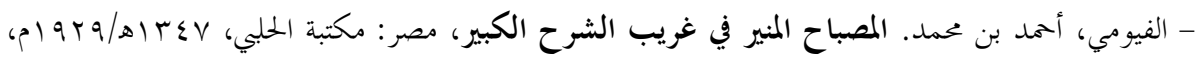

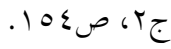

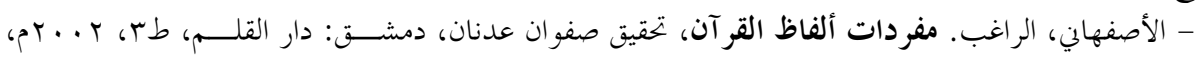

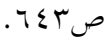

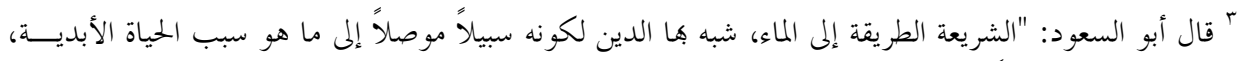

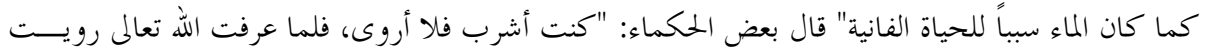

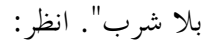
- الأصفهاني، مفردات ألفاظ القر آن، مرجع سابق، صا0ـ ـ. 


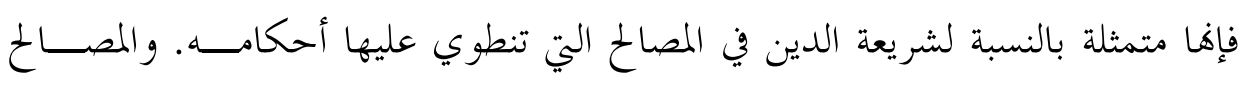

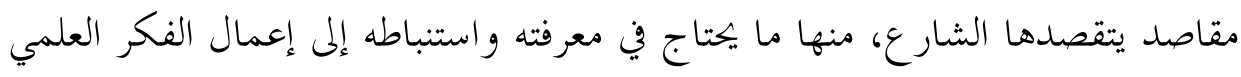

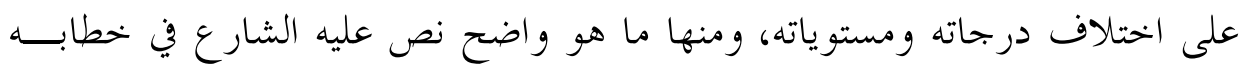

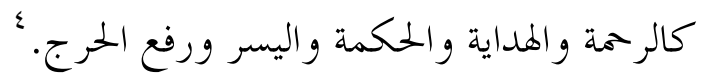

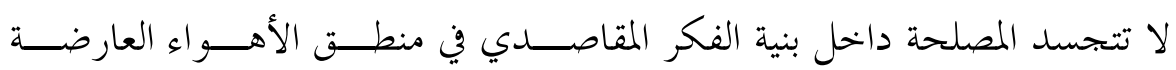

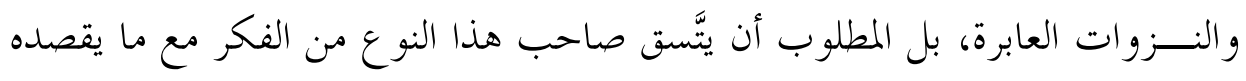

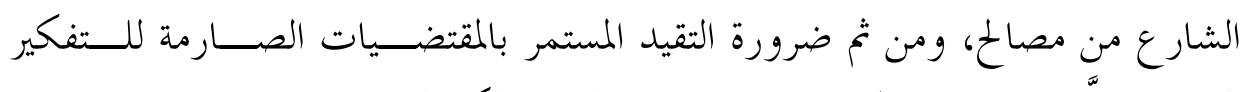

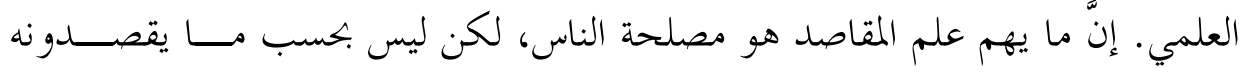

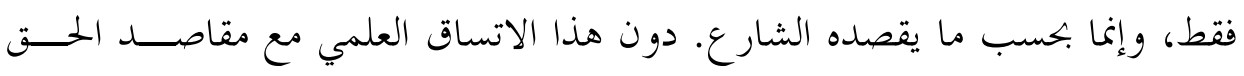

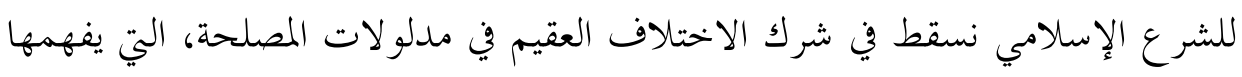

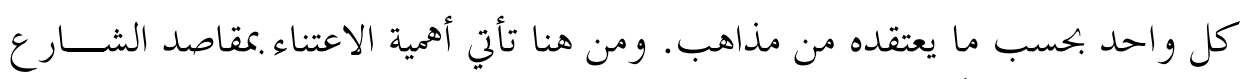

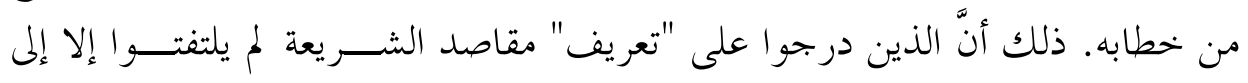

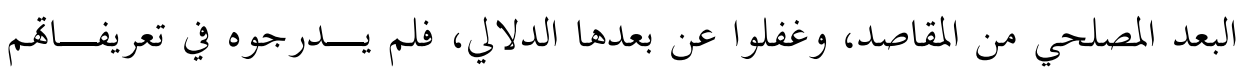
لمقاصد الشريعة.

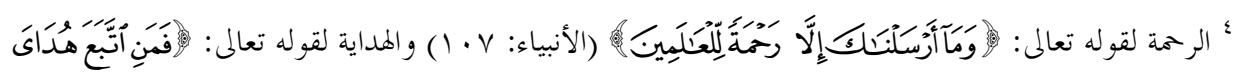

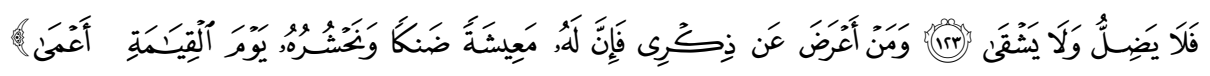

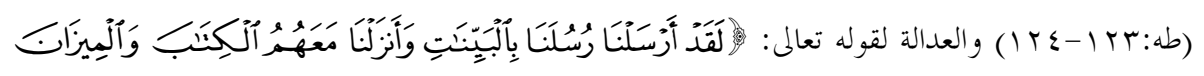

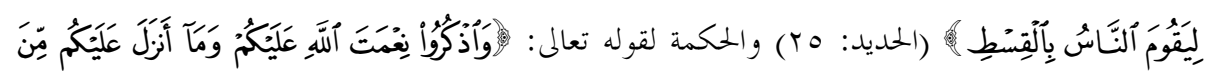

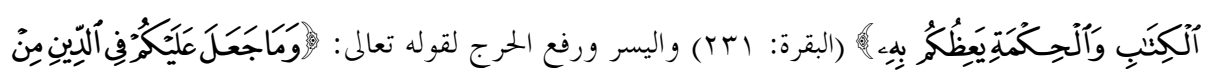

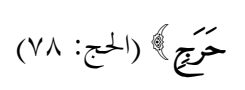

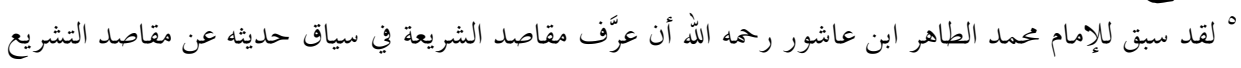

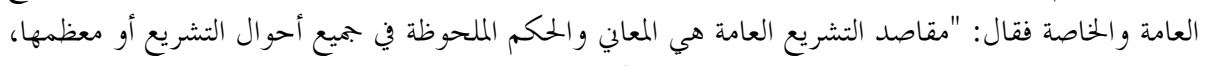

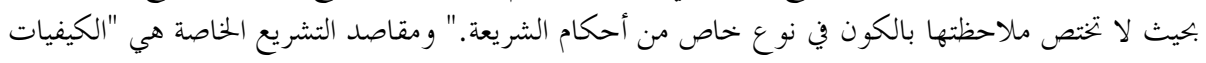

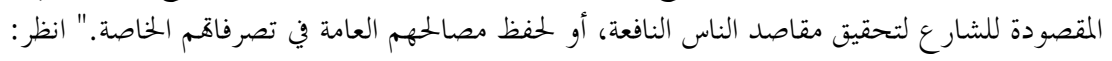

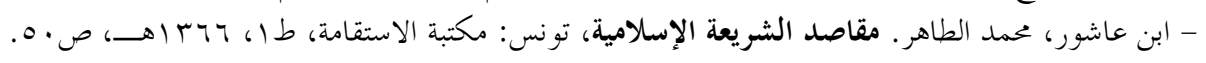

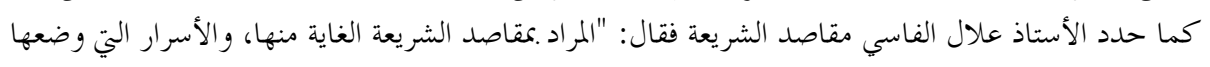

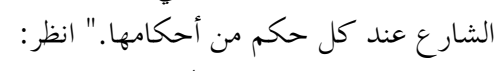
- الفاسي، علال. مقاصد الشريعة الإسلامية ومكارمها، الدار البيضاء: مكتبة الوحدة العربية، د.ت.، ص؟ّ. 


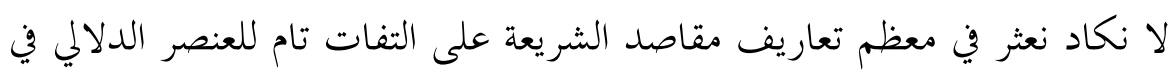

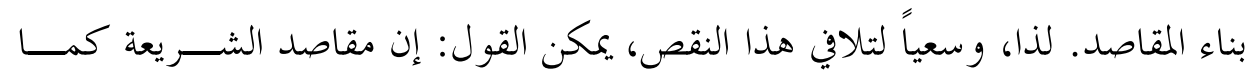

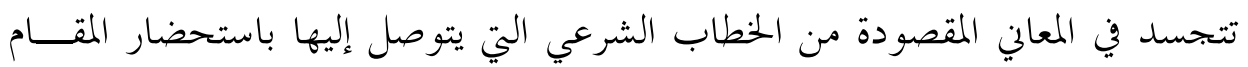

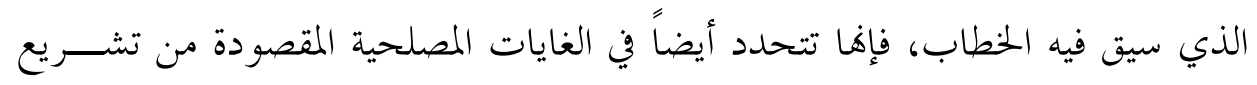

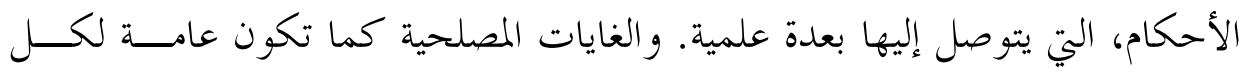

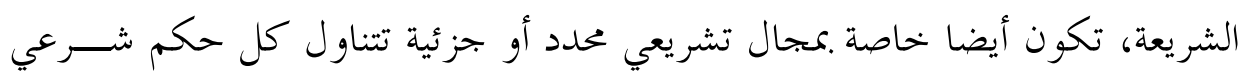

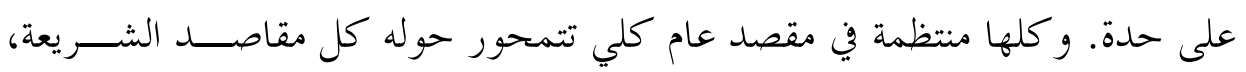

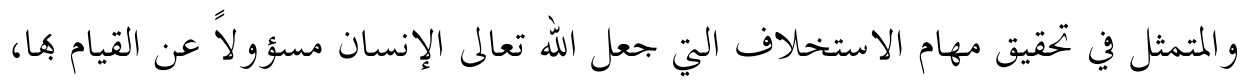

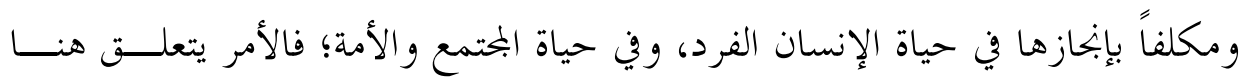

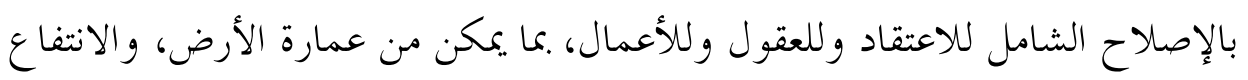
ما خلقه الله في دائرة الأخوة البشرية.

و الحاصل من هذا التحديد لكل من: الفكر، و الشريعة، والمقاصــــ، أن المقصـــود

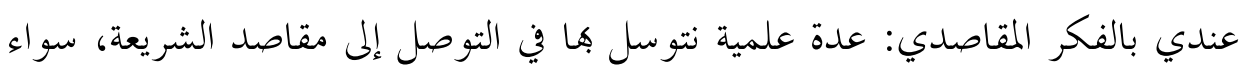

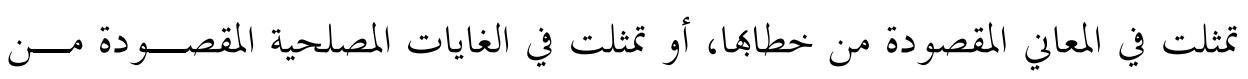
تشريع أحكامها العملية والاعتقادية.

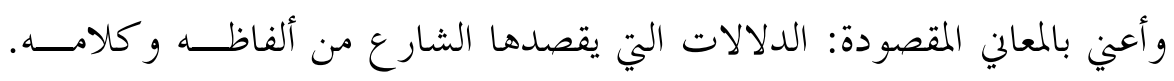

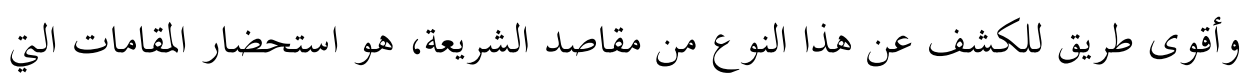

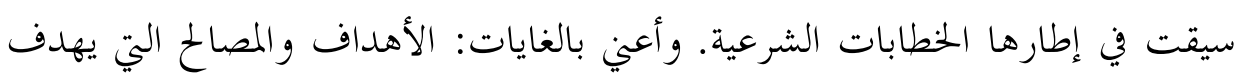

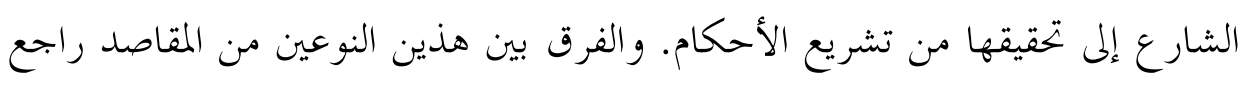

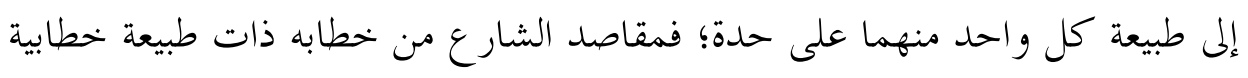

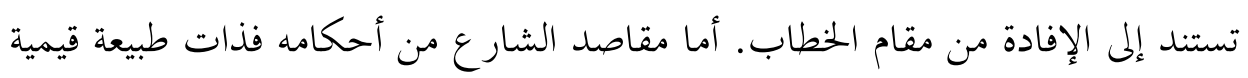

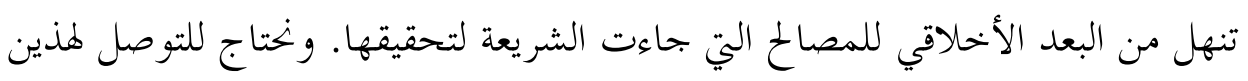

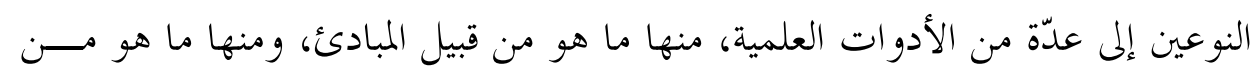
قبيل التقنيات، ومنها ما هو من قبيل المفاهيم. 
للعلم مر ادفات متعددة: نقول العلم ونعين ما يرادفه من معرفة أو إدراك أو ملكة.

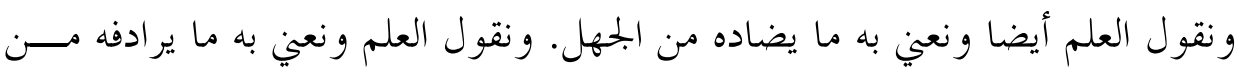

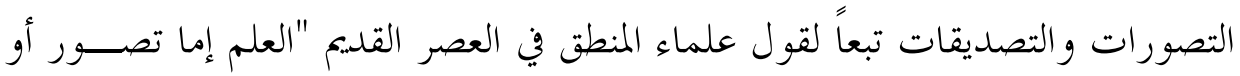

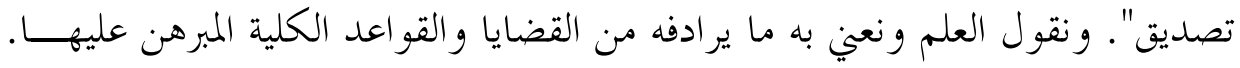

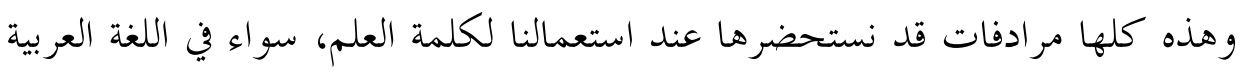
أو في ما كتبه علماء المنطق وأصول الفقه.

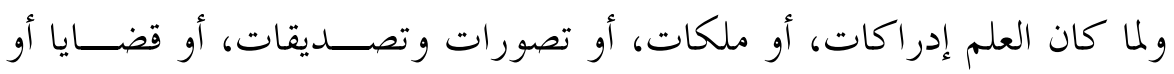

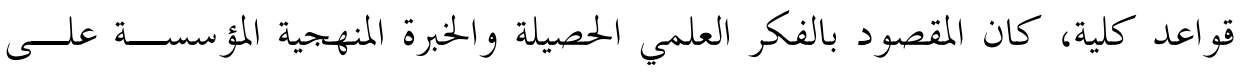

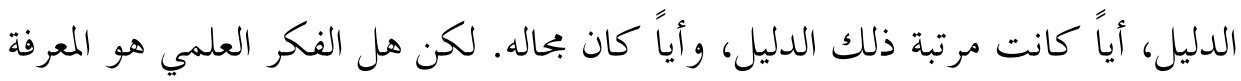

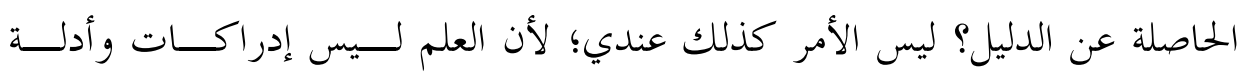

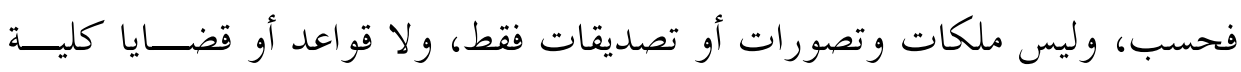

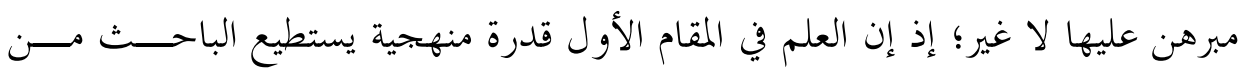

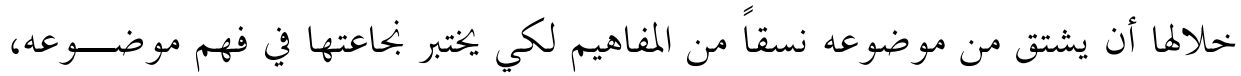

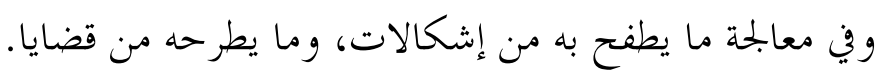

وقو ام الفكر العلمي هو هذه الطاقة المنهجية على تشغيل مكوناته الثلاثة الأساسية

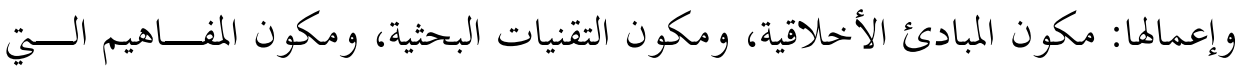

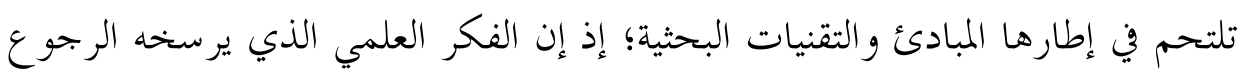

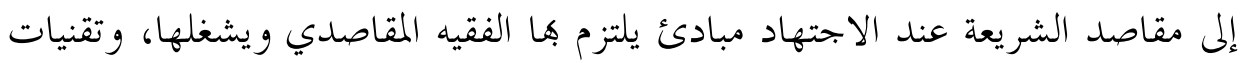

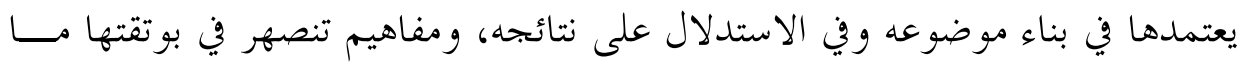
اعتمده من مبادئ، وما شغله من تقنيات.

\section{أولاً: مبادئ الفكر المقاصدي}

ينبغي للباحث أن يكون على وعي بأن معظم مبادئ الفكر العلمـي وتقنياتسـه،

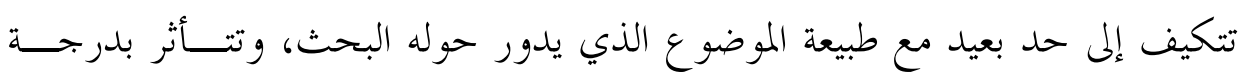


كبيرة بنوع الهدف الذي يتوخاه الباحث والمفكر. و ولذا يقال إن طبيعة الموضوع تحدد

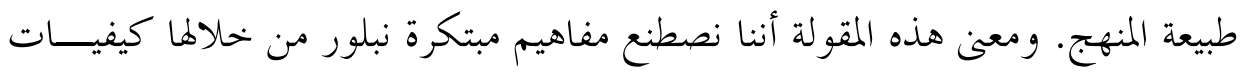

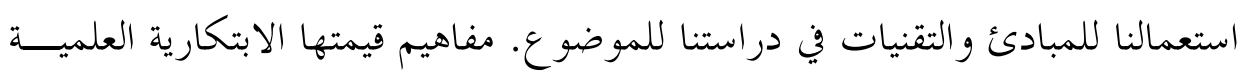

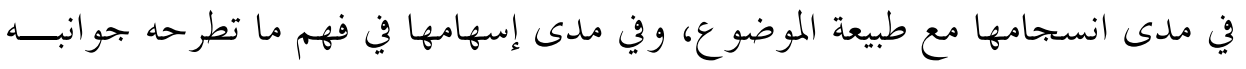
المختلفة من قضايا وإشكالات.

و الجحدير بالتبيه عليه هنا أنَّني عندما أبدأ بالحديث عن المبادئ، فلا يعني ذلك قولاًا

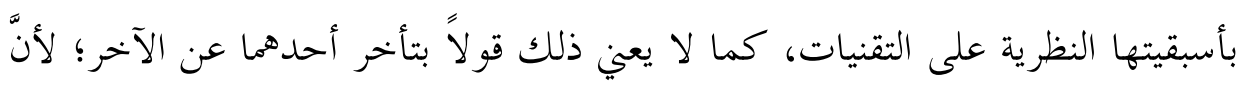

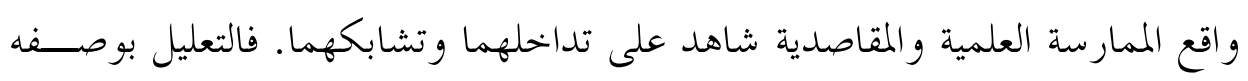

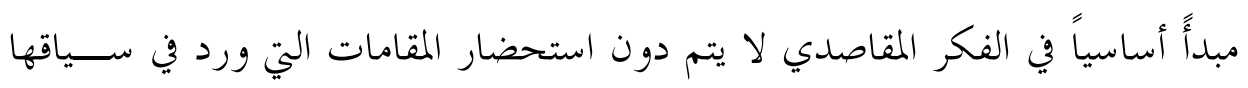

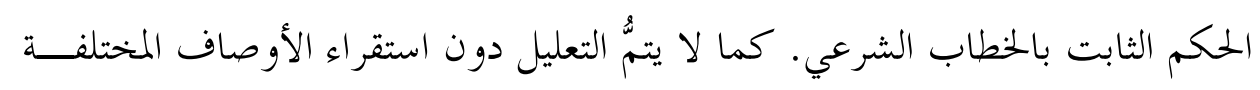

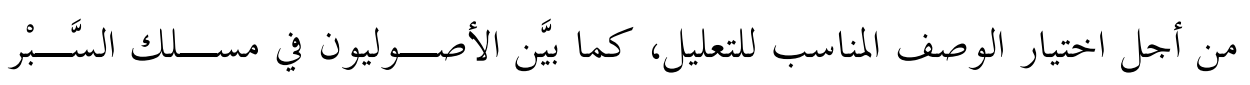
و التقسيم.

والمبدأ في اللغة العربية هو اسم ظرف من البدء. والبدء افتتاح الشيء. و المبــادئ

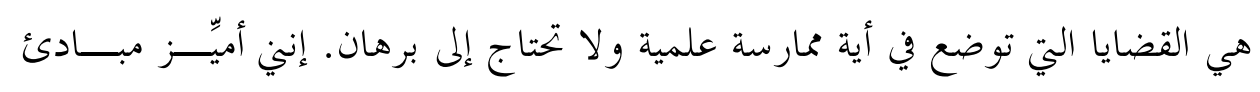

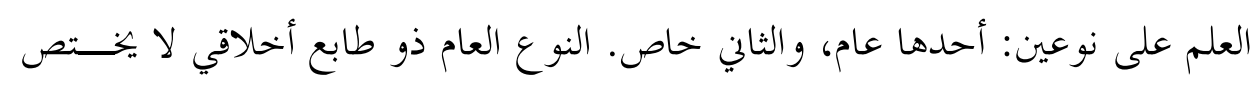

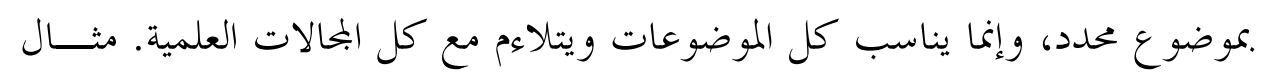

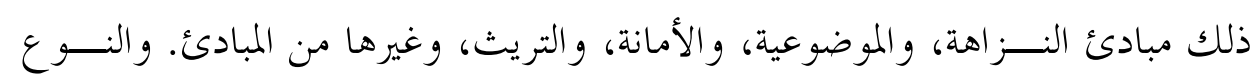

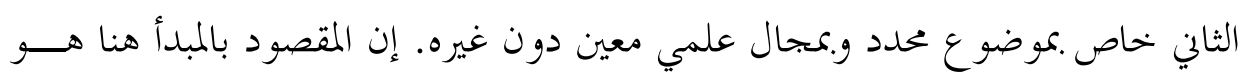

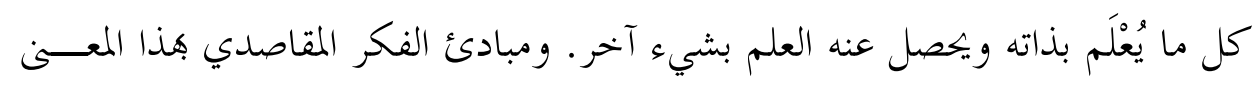

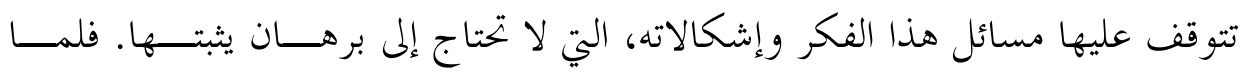

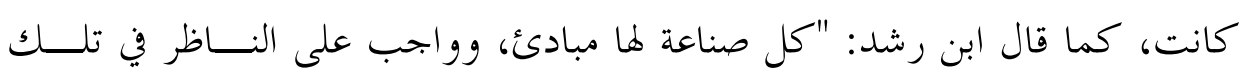

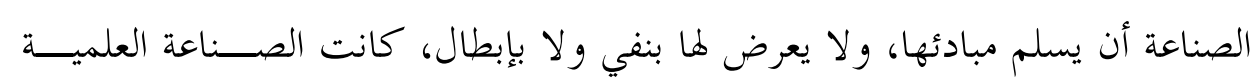


الشرعية أحرى بذلك." ويقوم الفكر المقاصدي على ثلاثة مبادئ هــــي: الفائـــدة، و التعليل، و الفطرة.

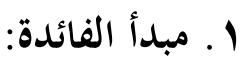

يرسّخ مبدأ الفائدة ليقظة ذهنية ولحركة عقلية لدى كل متفقه في الشرع الإســالامي،

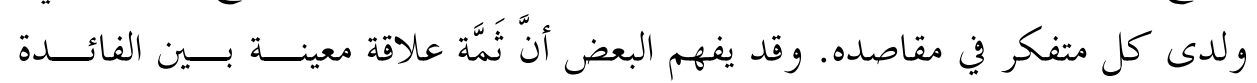

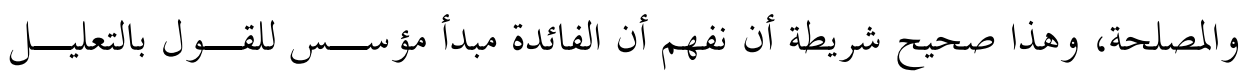

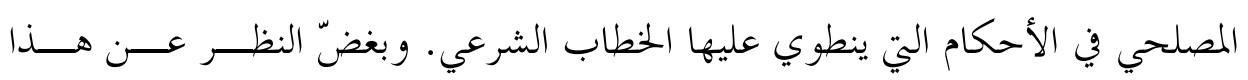

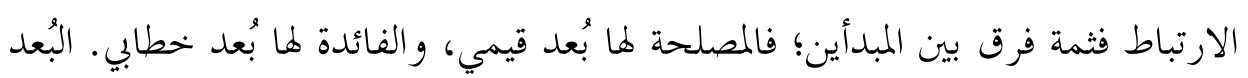

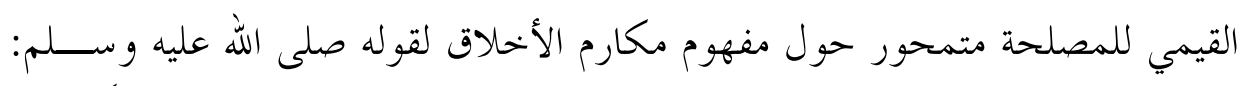
"بعثت لأتمم حسن الأخحلاق." وقد وقد أدرك ذلك كثير من علماء الإسلام؛ فقديماً قــال

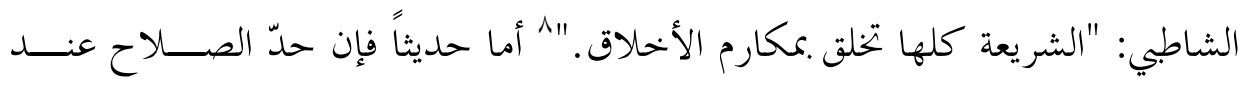

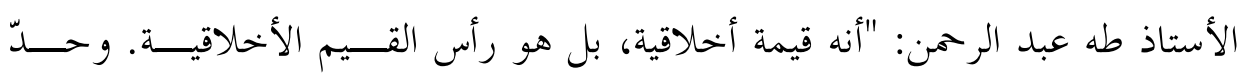

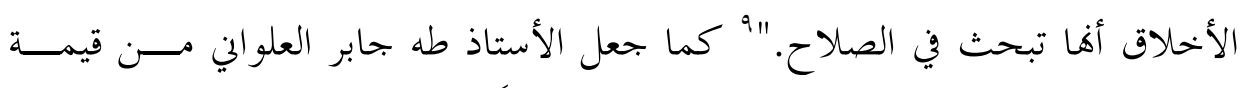

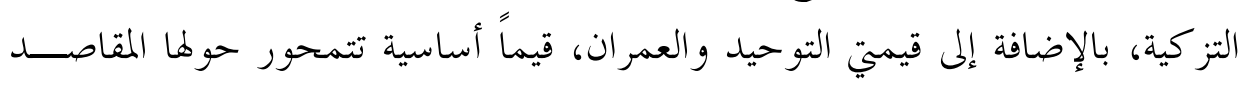

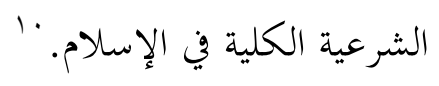

وأما مبدأ الفائدة فله بُعد خطابي؛ إذ تعني الفائدة تنــزيه الشارع في إنشاء خطابه

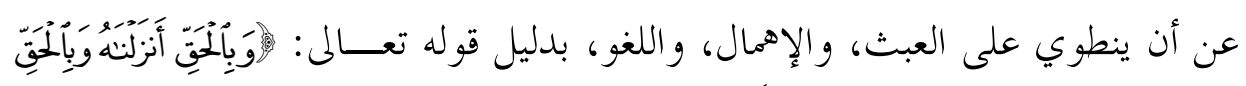

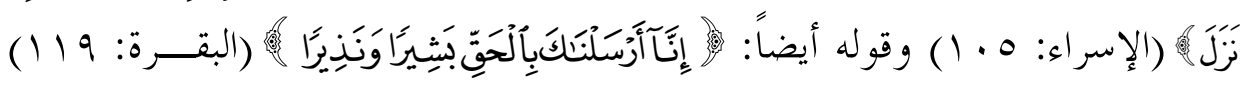

" ابن رشد، قدافت التهافت مع مدخل ومقدمة تحليلية للأستاذ محمد عابد الجابري، بــيروت: مركـز دراســات

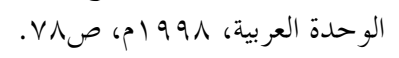

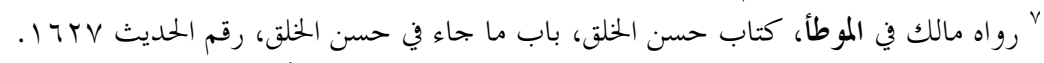

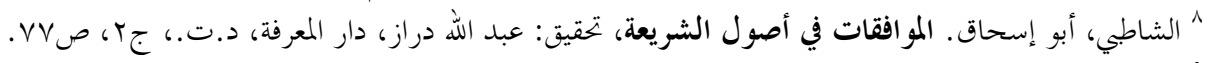

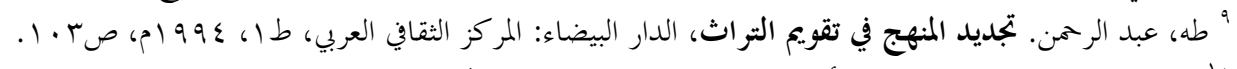

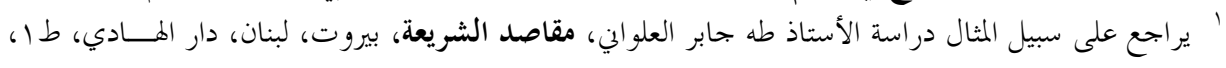




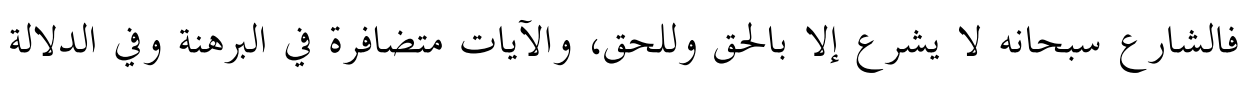
على هذا المبدأ.

إنَّ قليلاً من التدبر في هذه الآيات وأمثالها، يفضي إلى القول بأن مبــــأ الفائـــدة

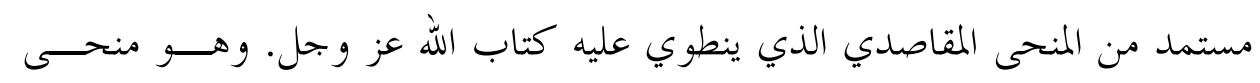

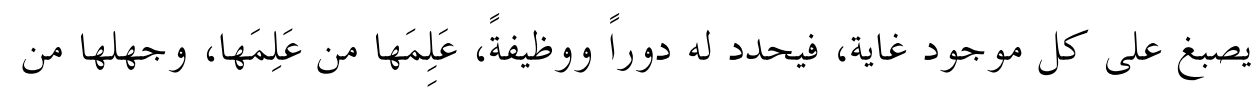

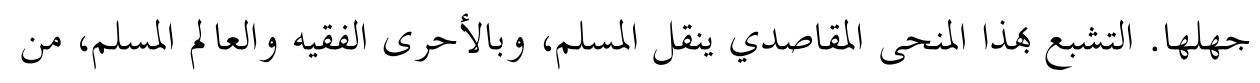

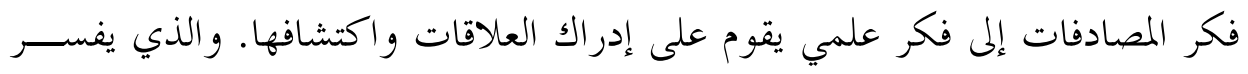

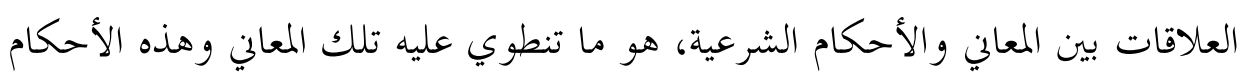

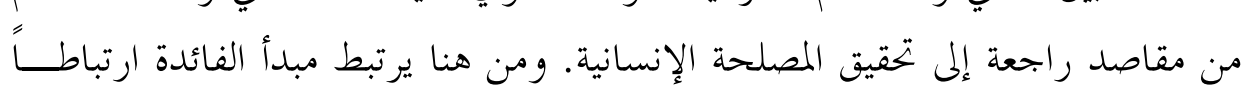

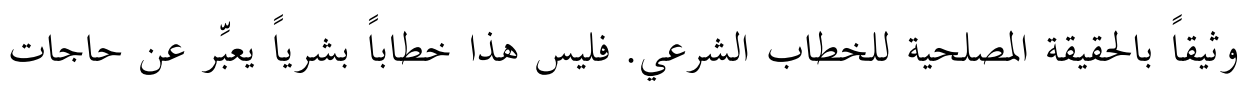

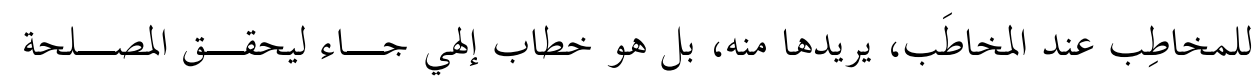

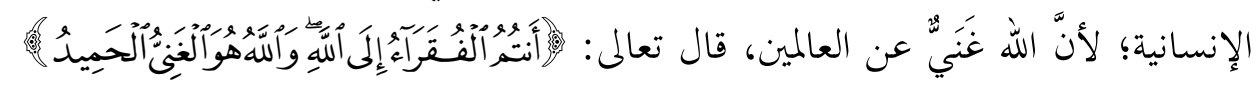

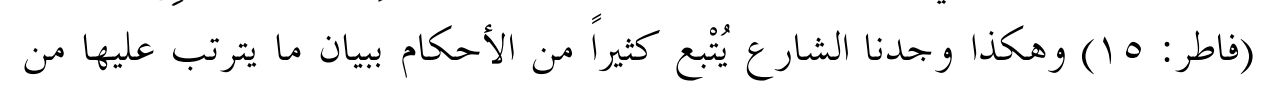
مصالح راجعة إلى المكلف وها.

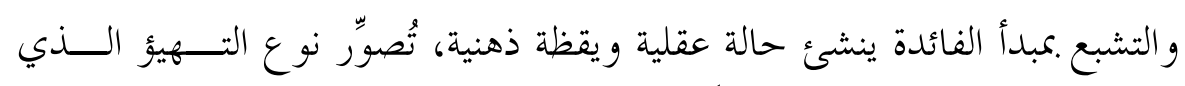

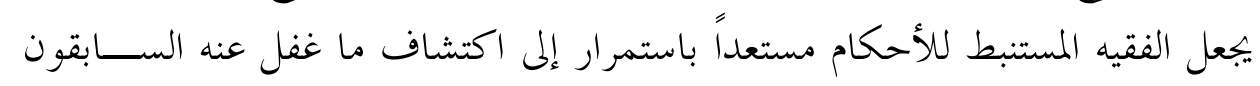

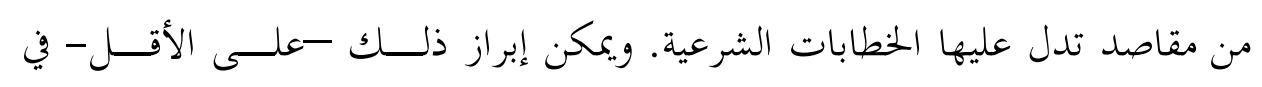

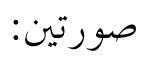

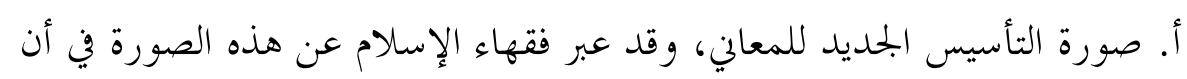

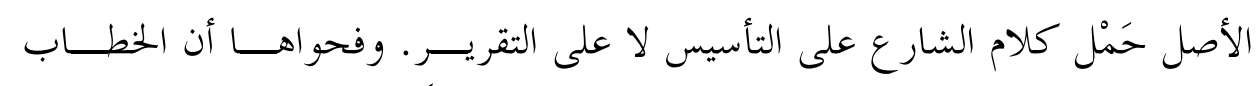

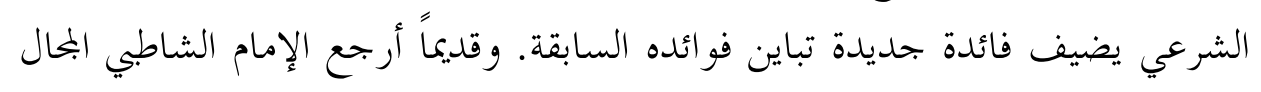

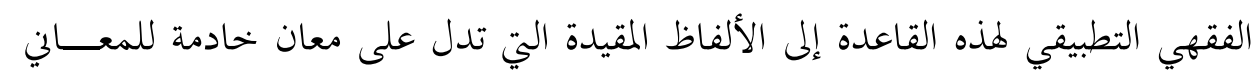

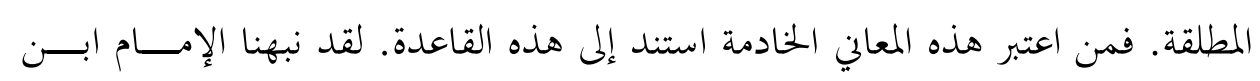




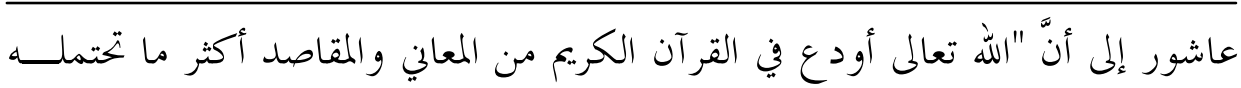
الألفاظ في أقل ما يمكن من المقدار، بحسب ما تسمح به اللغة الوارد هو هـا." "ل ب. صورة عدم الإهمال الخطابي، وقد بحسدت في قاعدة إعمال الكلام أولى مــن

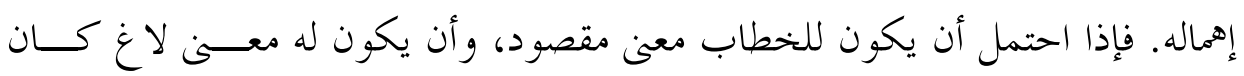
حمله تبعاً لمبدأ الفائدة على ما هو مقصود أولى ألى. يتقيد في ضوء هذه هذه القاعدة فهم الدلالة

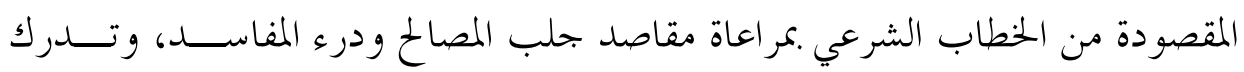

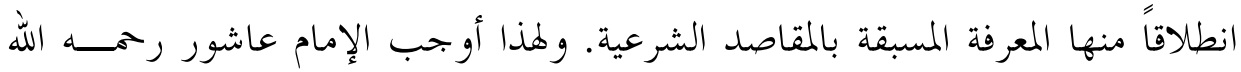

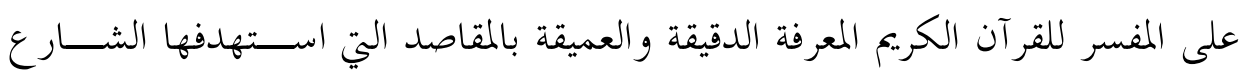
سبحانه من نزوله.

إن كثيراً من الأحكام الشرعية والأفهام العلمية في شريعتنا الإسلامية مبنية علــى لــ

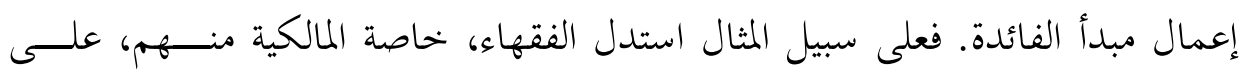
مشروعية بعض المعاملات كالكفالة و الوكالة بآيات قرآنية. فعلى الرغم من أها وردت

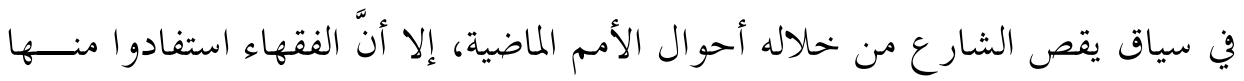

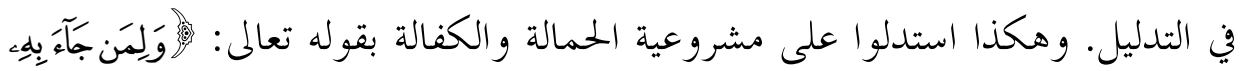

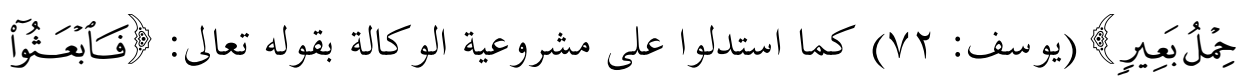

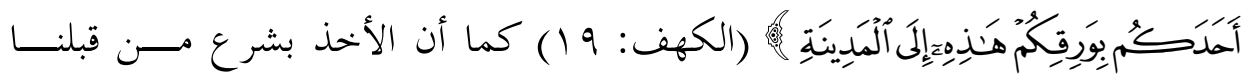

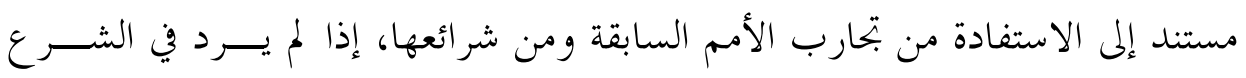

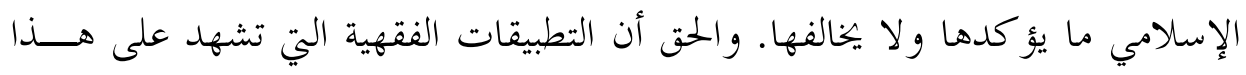

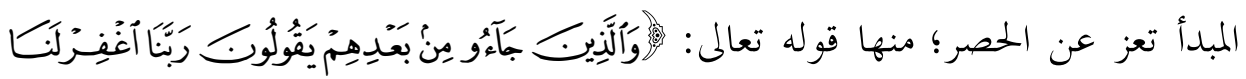

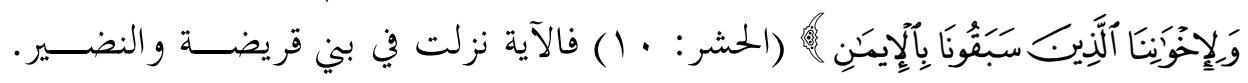

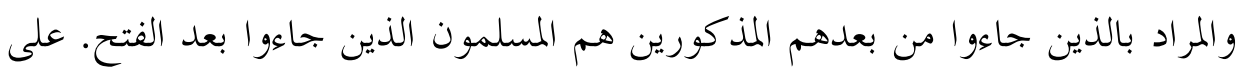

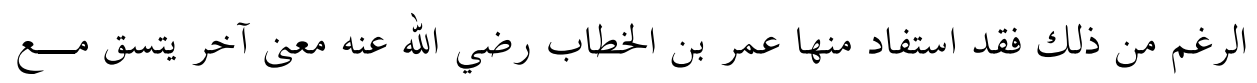

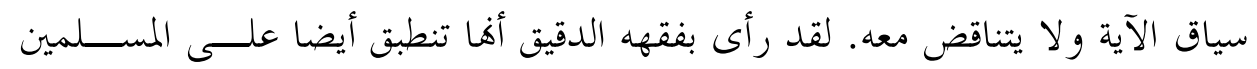

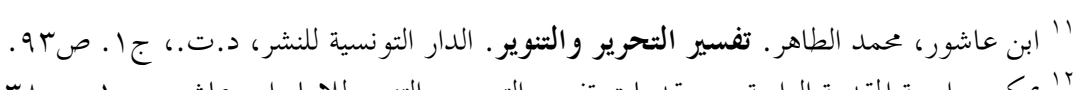

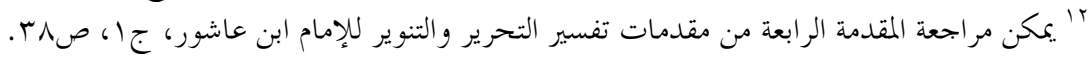




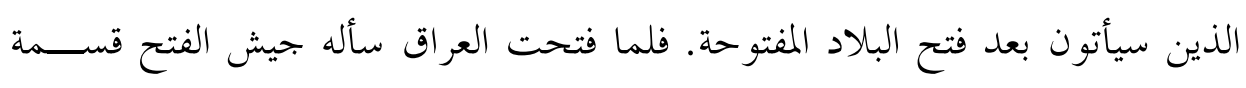

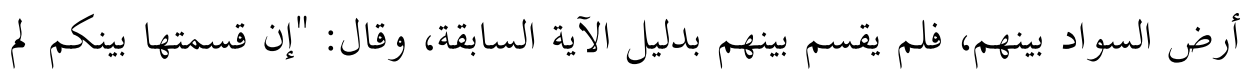

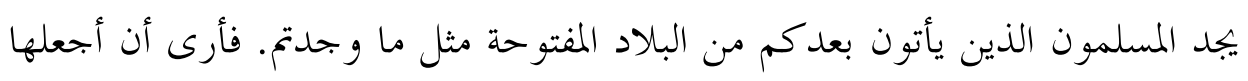

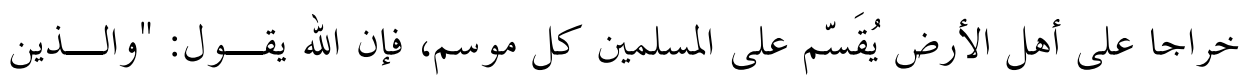

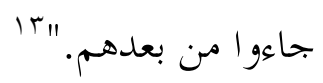

و الحاصل أن مبدأ الفائدة في الفكر المقاصدي مستند إلى معطيين علميين يشــهـد

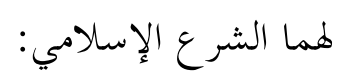

أولمما معطى المقام؛ إذ لا سبيل إلى العلم .مقاصد الخطاب الشرعي دون تبيين مقام

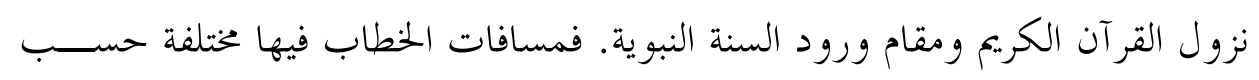

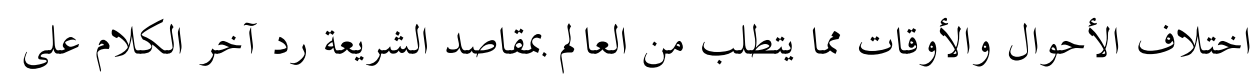

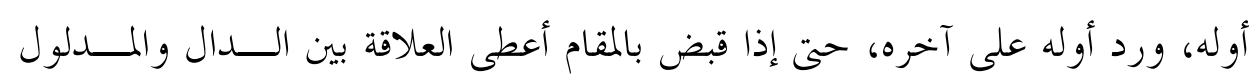

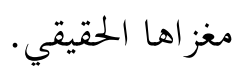

وثانيهما معطى الانطواء؛ ذلك أن عملية الإحاطة بالعلــل واسـتيعاب المعــاني

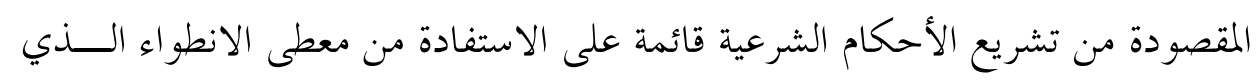

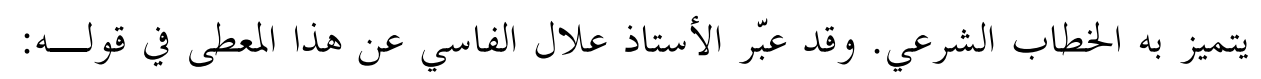

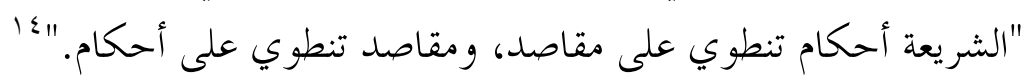
وإذا سلمنا بمبدأ الفائدة فإنه من غير المنطقي القول بأنه لم يبق في الحكم المنسوخ

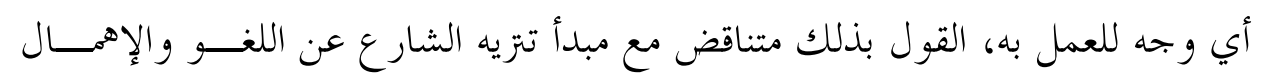

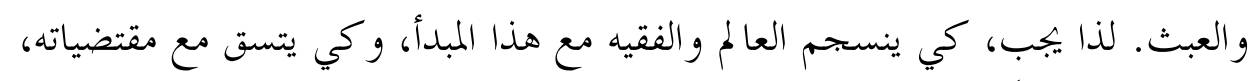

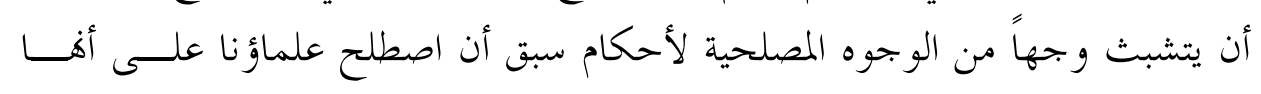

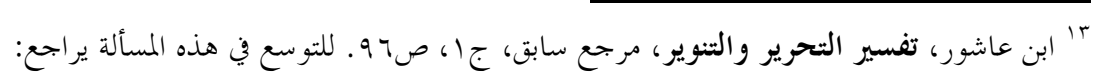

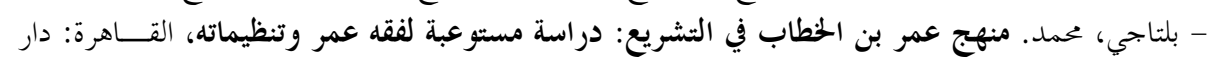

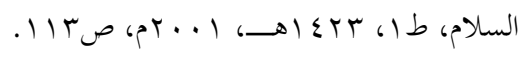

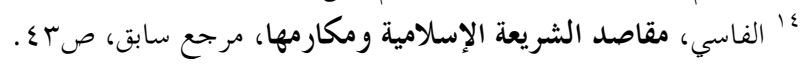




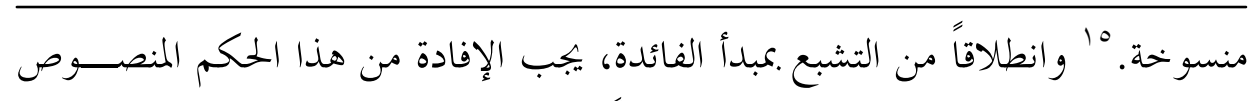

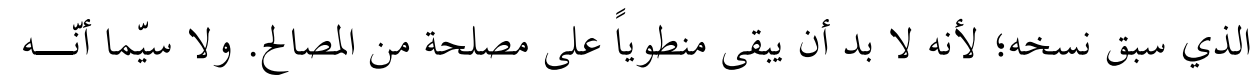

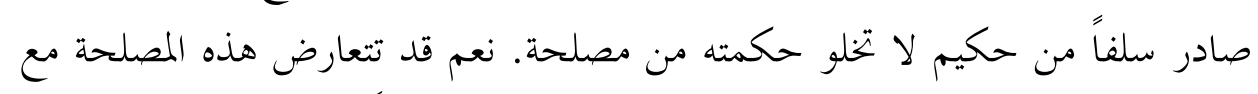
مصلحة أخرى أعظم منها، لكن هذا التعارض لا ينهض دليلاً على الغفلة عن المصلحة

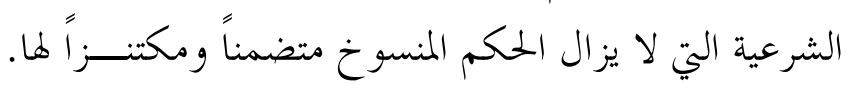
المطلوب دائماً هو تقلديم أعظم المصلحتين، ويبقى في الحلكم المنسوخ "ما شاء من

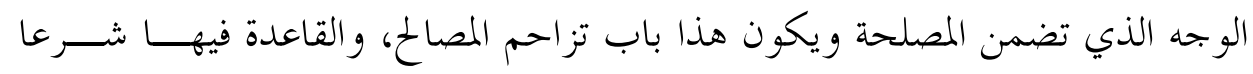

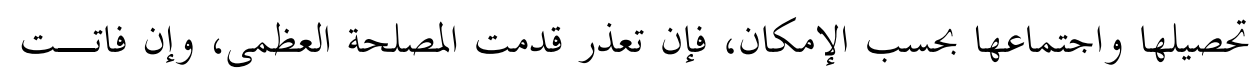

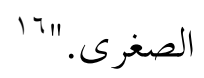

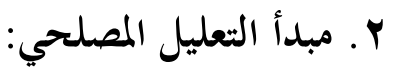

التعليل كشف للأساس الذي لاحظه الشارع في تشريعه لأحكامـــه. و لا يتــأتى

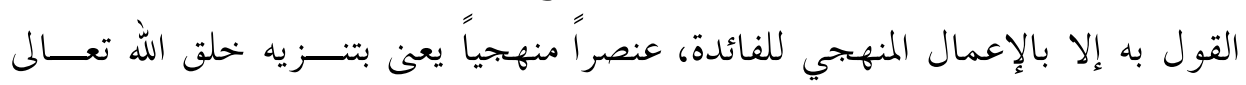

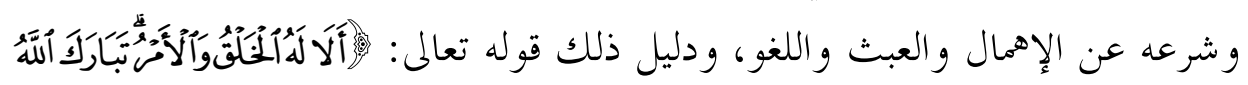

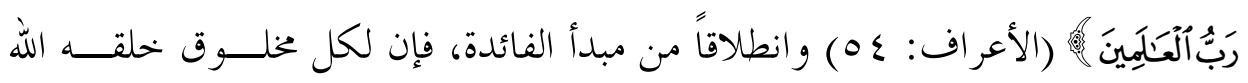

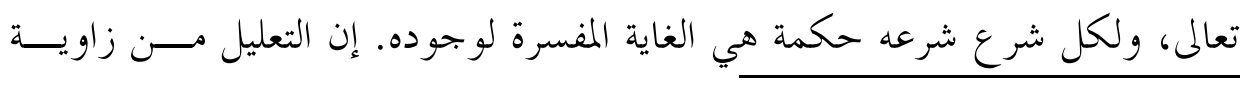

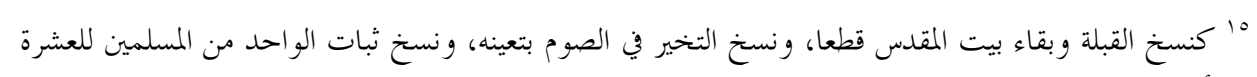

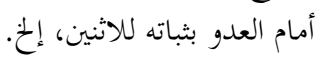

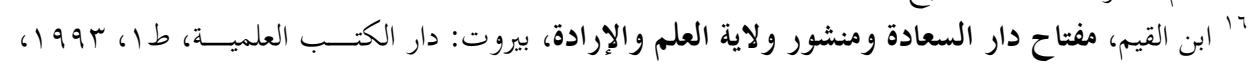

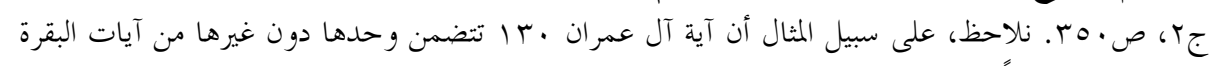

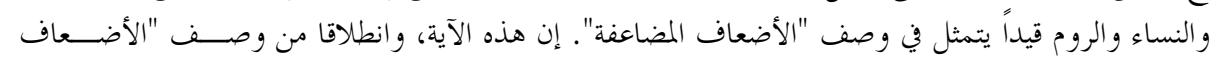

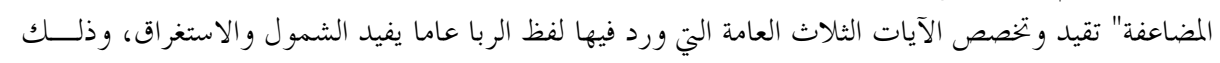

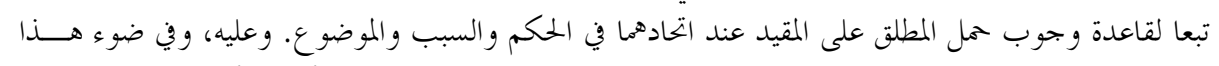

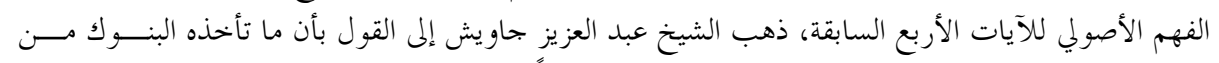

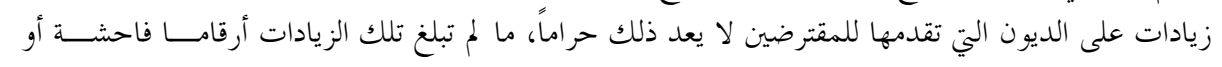

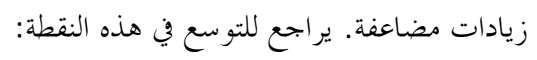

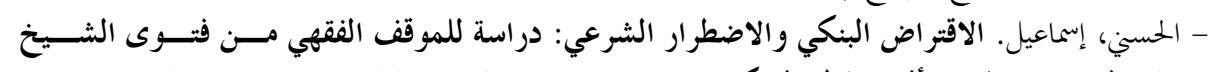

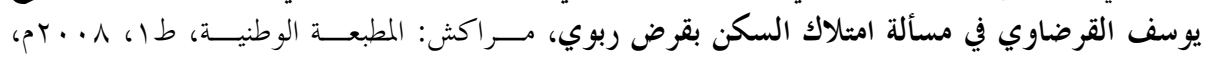




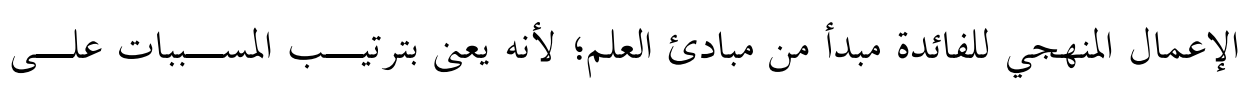

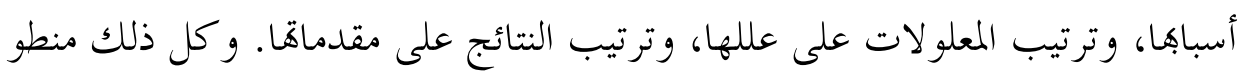

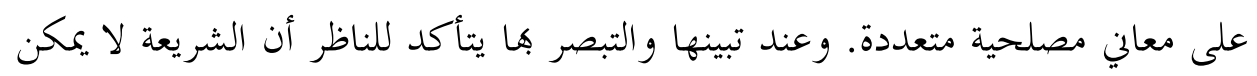

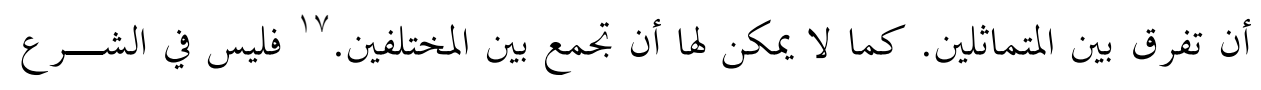

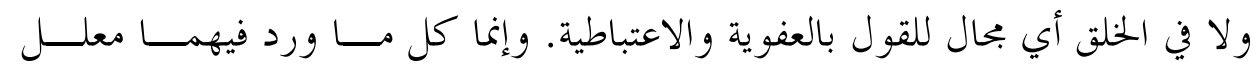

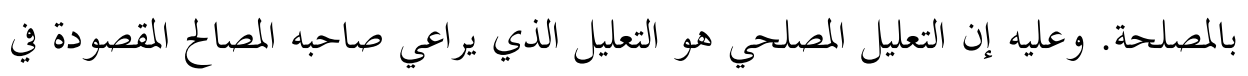

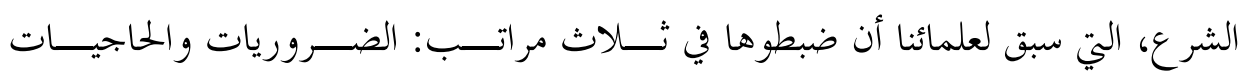

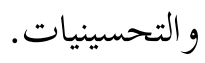

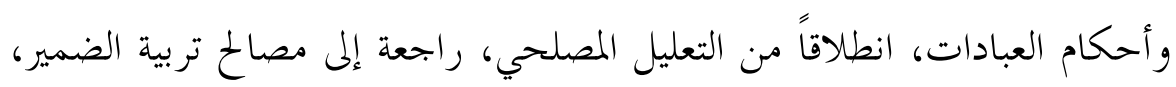

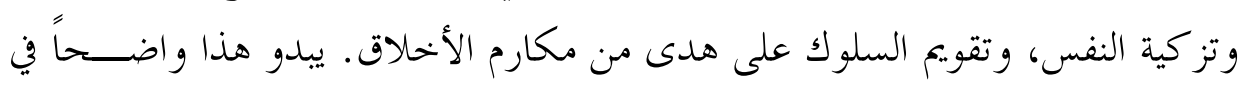

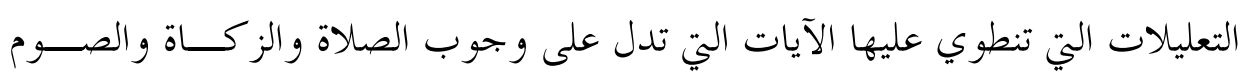

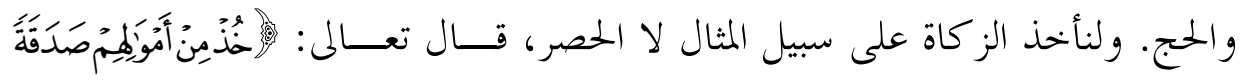

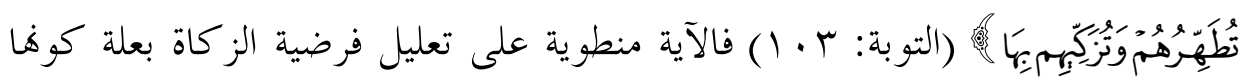

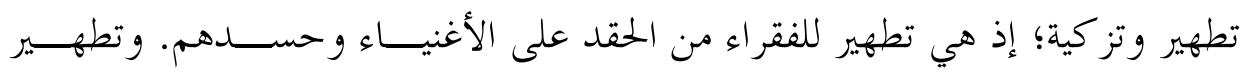

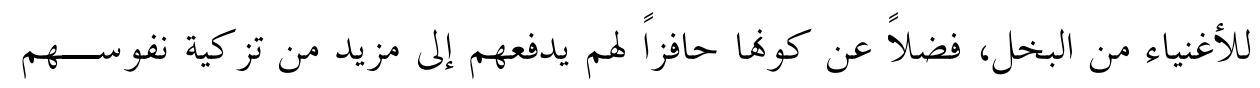

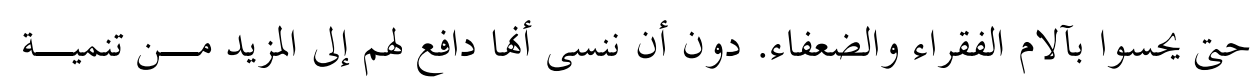

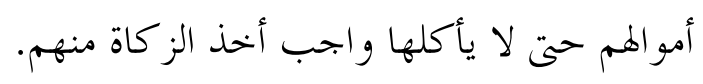

وثمّة تعليل التعليل في أحكام المعاملات؛ إذ تعود أحكام المعــاملات إلى مصـــالح

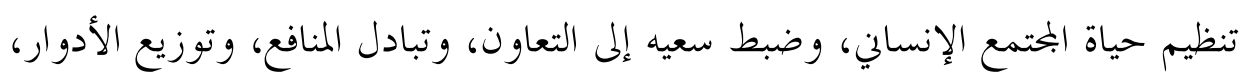

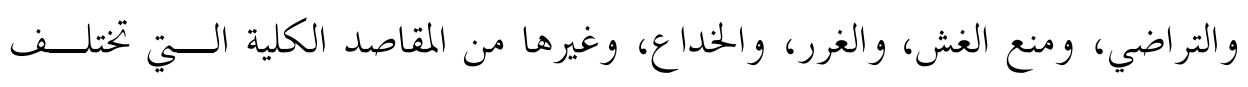

لا ابن القيه، الداء والدواء، مرجع سابق، ص. ب. ب. بين ابن القيم جملة من الأمثلة التي ظن البعض أها متباينــة في

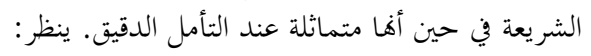
- ابن القيم، إعلام الموقعين عن رب العالمين، ضبط: حسين عبد الحميد، دمشق: دار الفكــ، د.ت.، جب، 


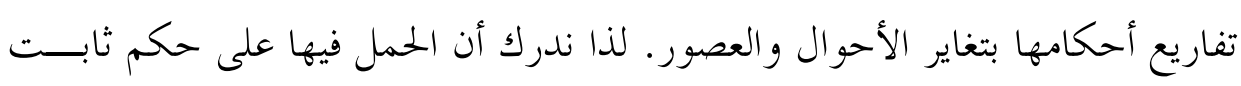
حرج ومشقة، يمسان الكثير من طبقات الأمة.

يجب مر اعاة هذه المصالح في المعاملات؛ لأن واقعها الإنساني، كمــــ لا يســلم في

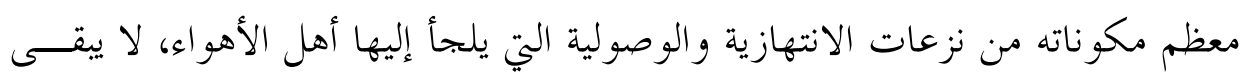

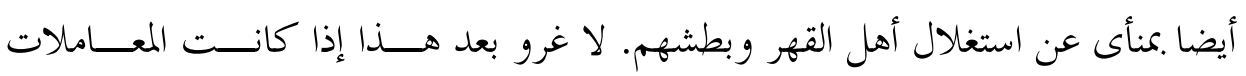

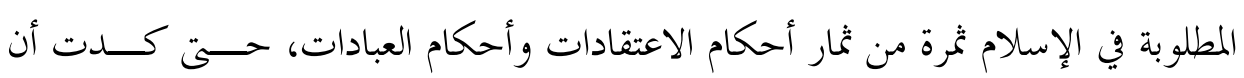

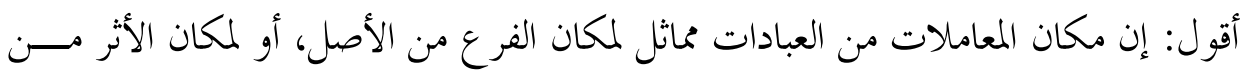

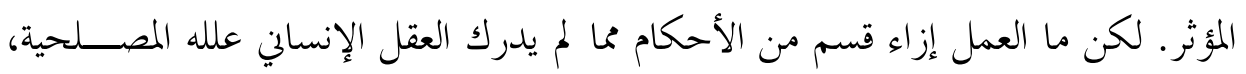

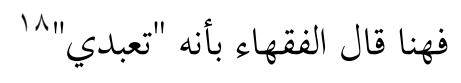

والتعليل، بوصفه كشفاً للأساس الذي لاحظه الشارع في تشريعه لأحكامه المختلفة،

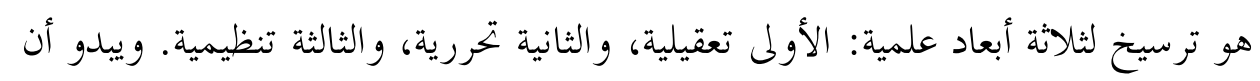

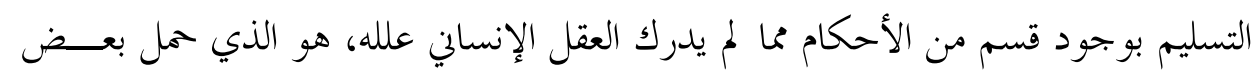

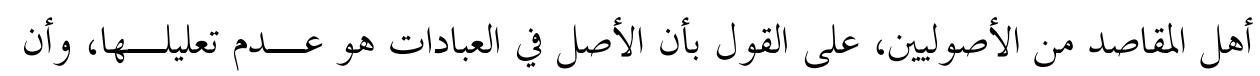
الأصل في المعاملات هو تعليلها.

وعلى كل حال إن تضارب نتائج التعليل، وتعذر الوقوع على العلــل المقصــــودة

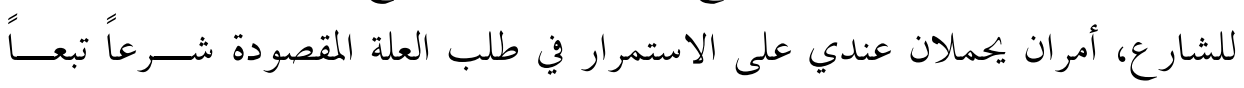

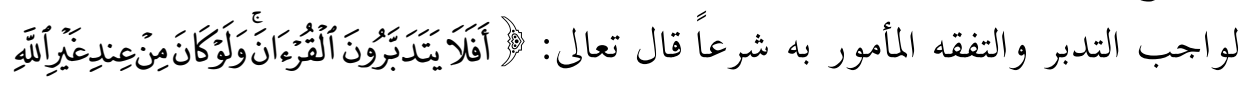

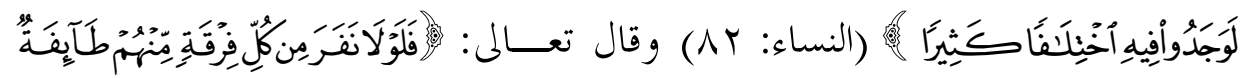

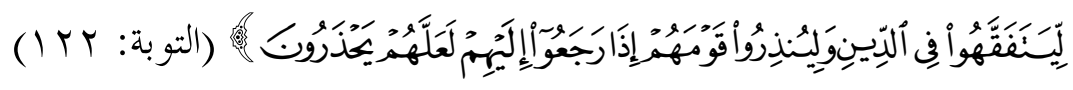

إن هذا الاستمرار في طلب التعليل هو الذي يفسر إقدام أهل المقاصد على تعليـــل

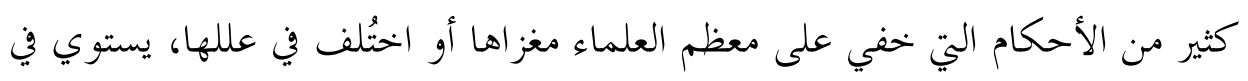

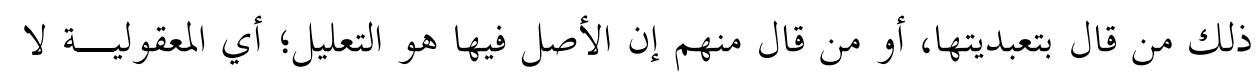

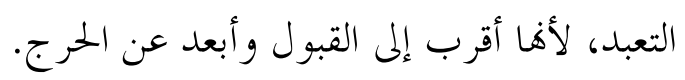

^" من ذلك عدد الركعات واختلافها من صلاة لأخرى، وجعل الصيام في شهر معين، إلخا. 


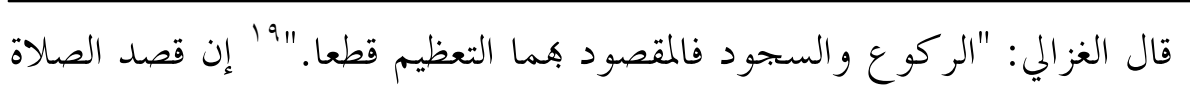
هو الخضوع لله سبحانه بإخلاص التوجه إليه، و الانتصاب على قدم الذلة بين يديـهـ،

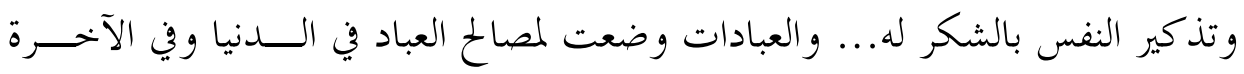
على الجملة، وإن لم يعلم ذلك على التفصيل، ويصح القصد إلى مســبقاةًا الدنيويــة

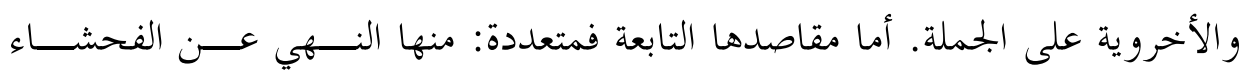

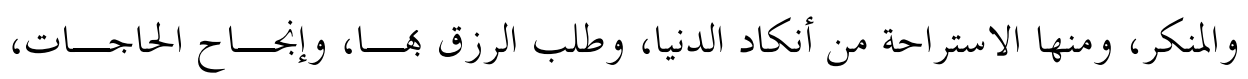
وطلب الفوز بالجنة. "و كذلك سائر العبادات، فيها فوائد أخروية، وهي العامة، وفو ائد

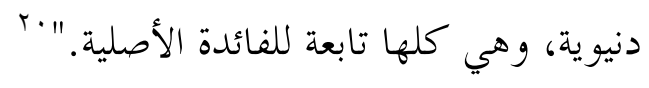
و في تقديري إن وظيفة التعليل هي إظهار لمعقولية الأحكام الشرعية كمظهر مــن

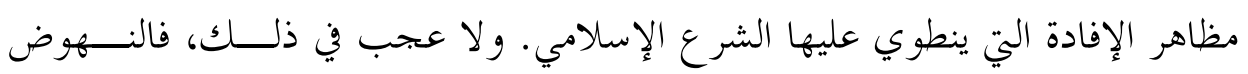

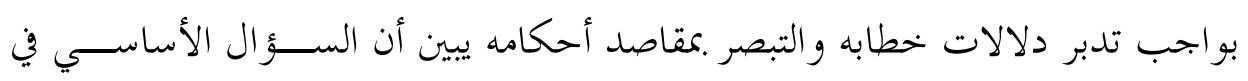

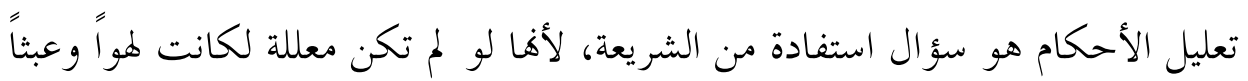

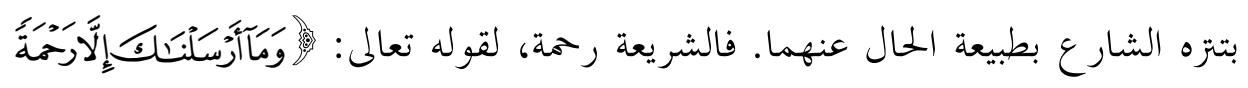

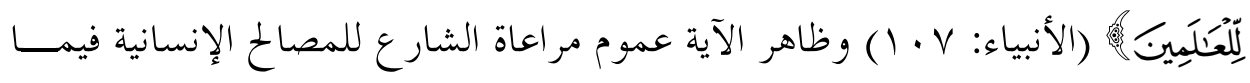
شرع من الأحكام، فلو أرسل بحكم لا مصلحة للناس فيه لكان إرسالاً لغير الرحمة لأنه الأله

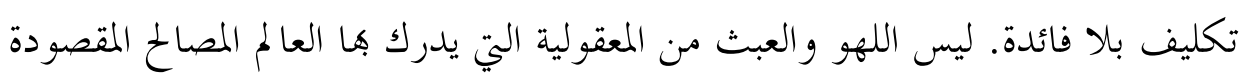

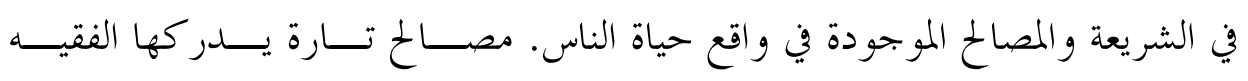

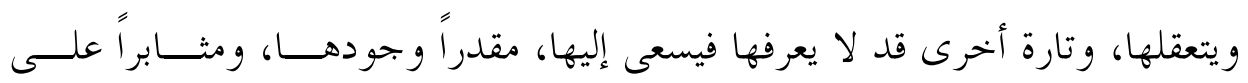
كشفها و تبينها. لا يمكن في نظري أن يوجد حكم شرعي واحد فئ غير معقول. أعني أنه

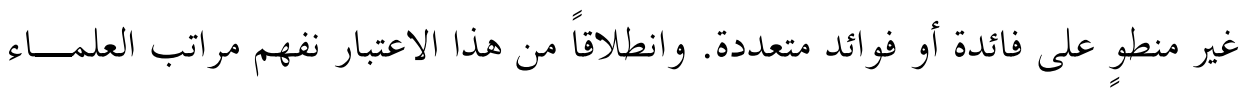
و تفاضل مو اقعهم في فهم المقاصد؛ لأكم متفاوتون في قرائحهم و وي مبلغ علمهم.

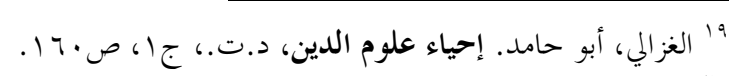

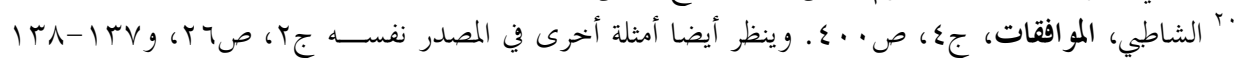

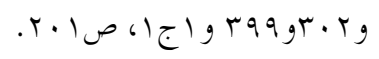




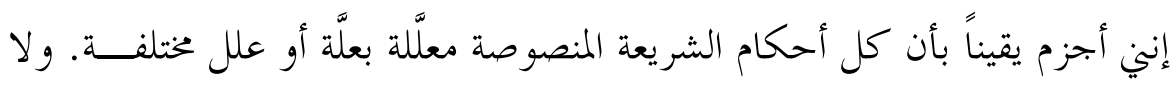

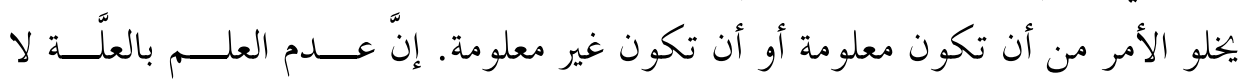

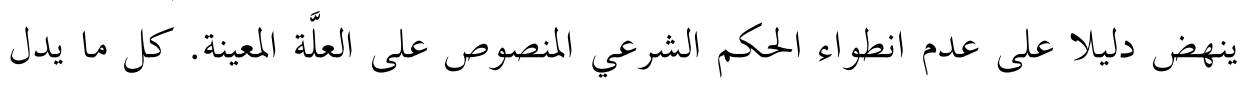

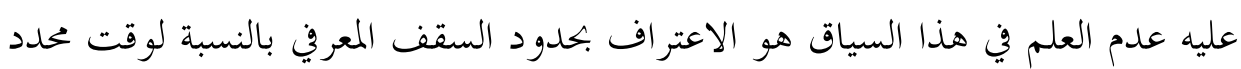

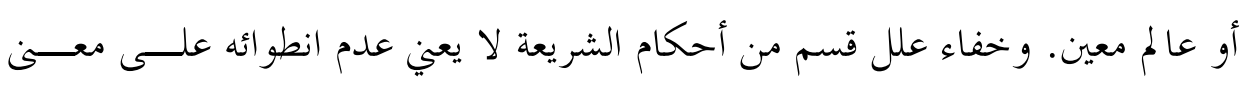

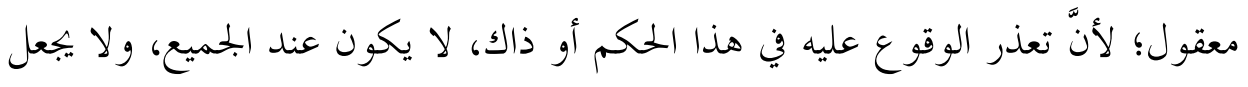

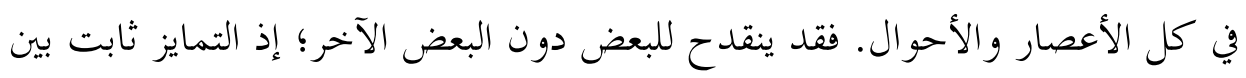

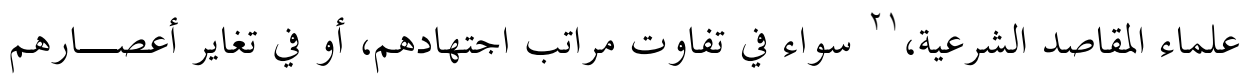

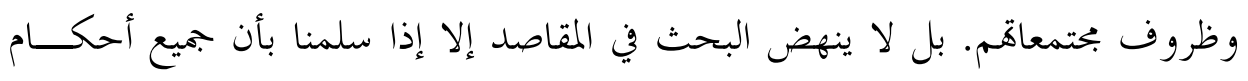

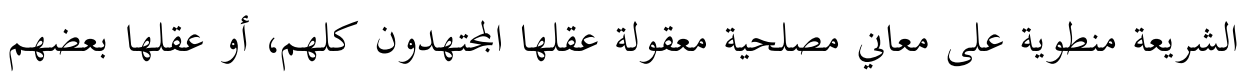

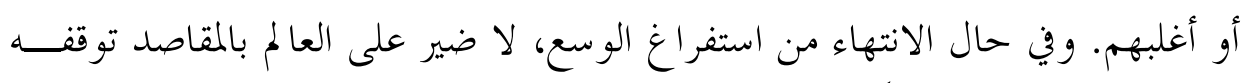

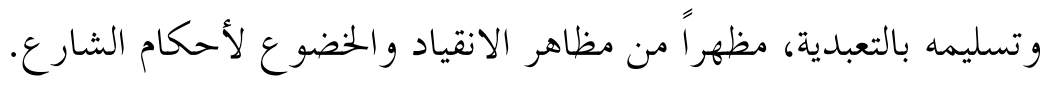

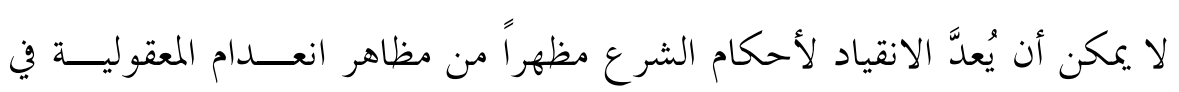

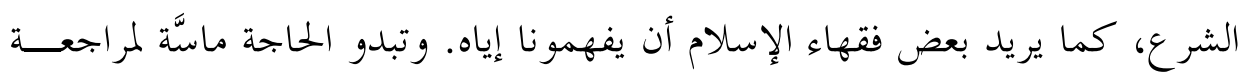

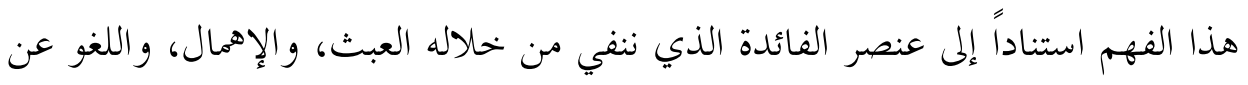

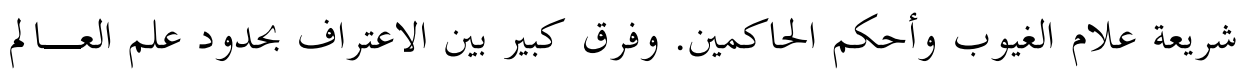

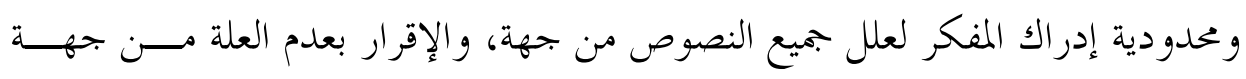

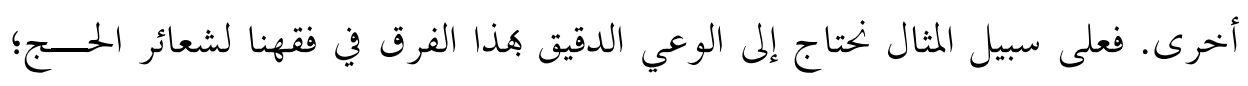

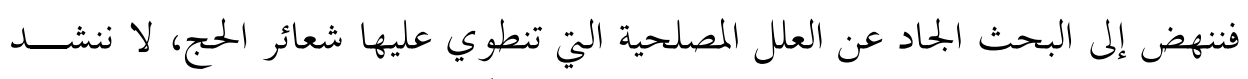

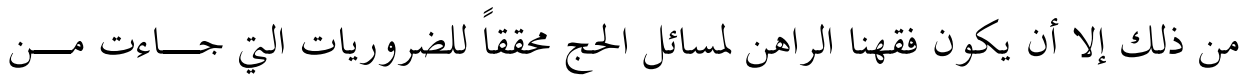

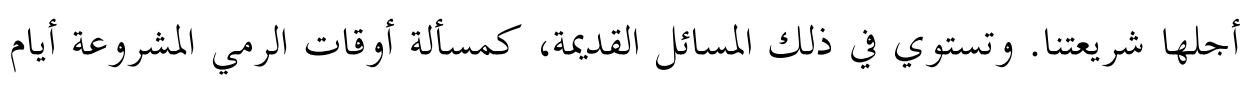

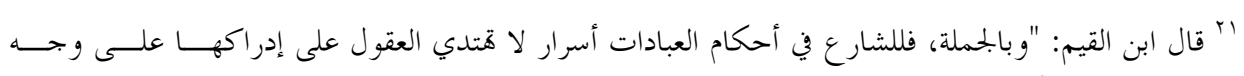

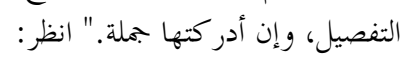

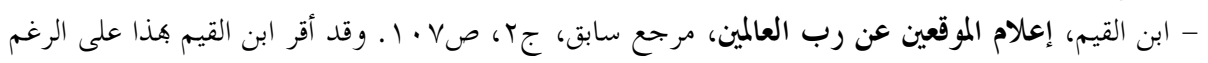

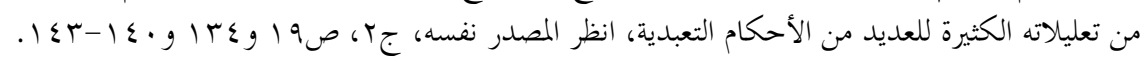




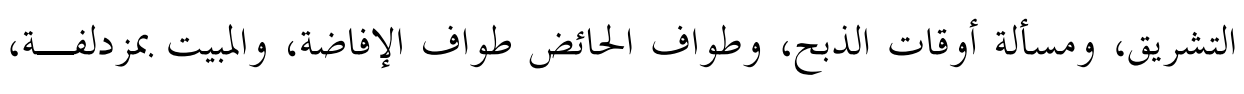

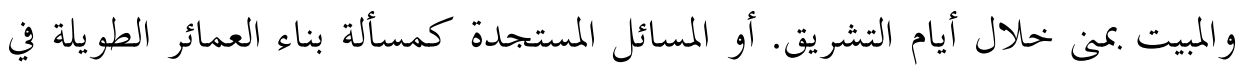

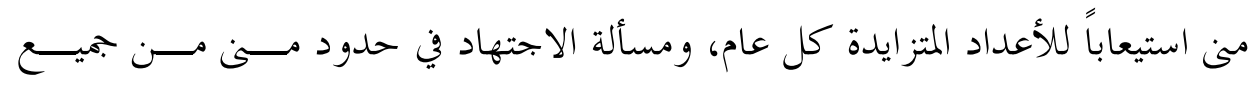
الجهات، ومسألة الإحرام من جدة وغيرها من منافذ الدخول غير المواقيت... . . .

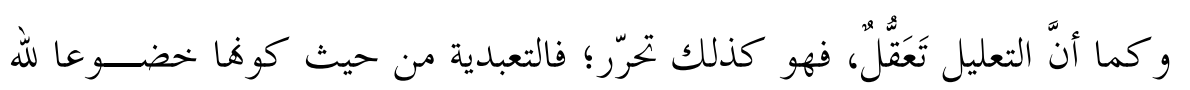

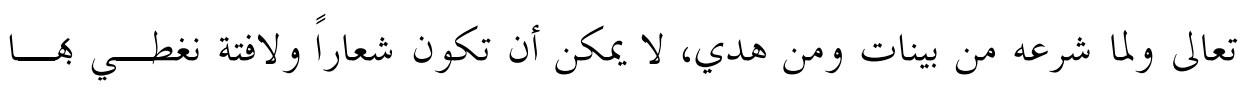

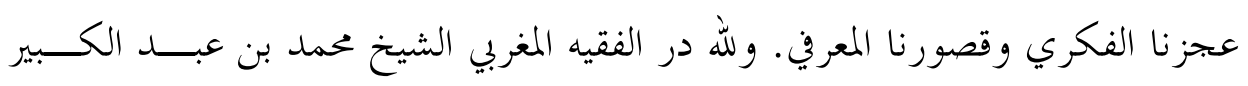

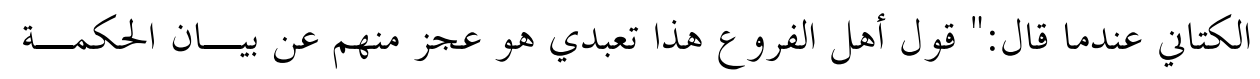

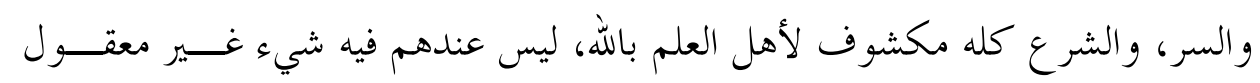

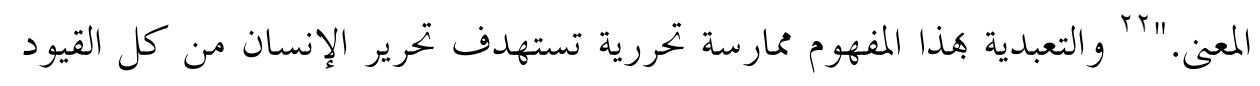

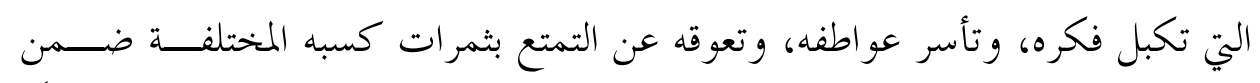

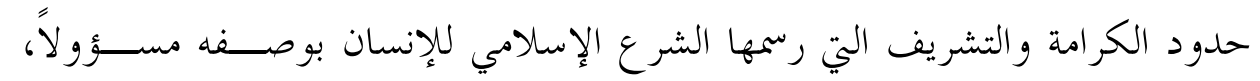
وكونه خليفة لله تعالى على الأرض. و التعليل بالإضافة إلى كونه تعقلاً وتحرراً فإنه تنظيم كذلك؛ ذلك أن المطلوب في

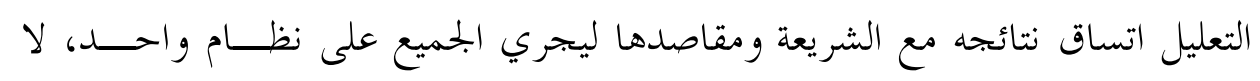

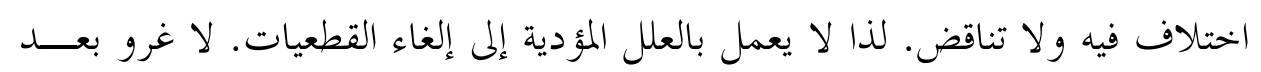

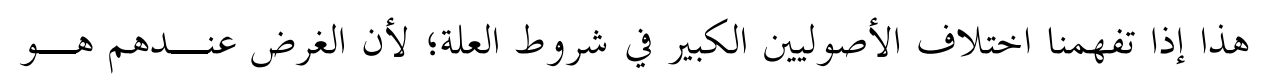
ضبط الأقيسة، حتى لا تتناقض مع الفروع المنصوصة. إن كمال الاتساق الذي جاءت

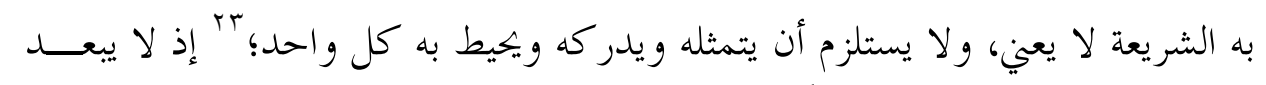

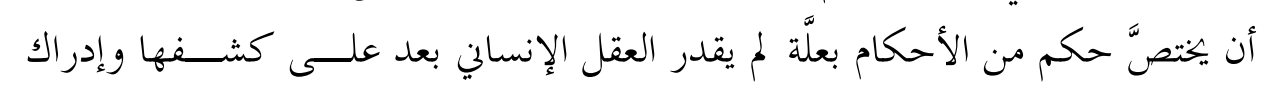

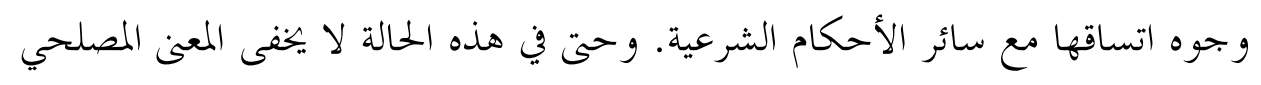

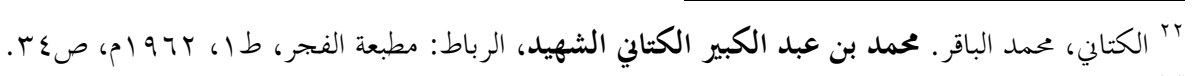

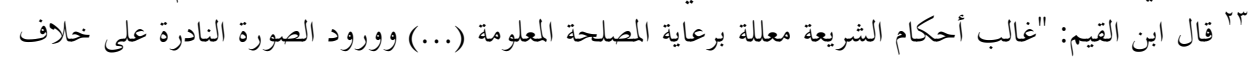

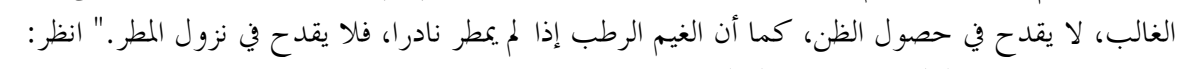

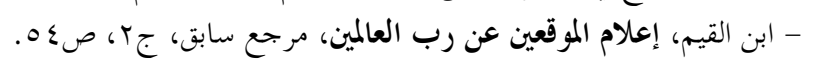




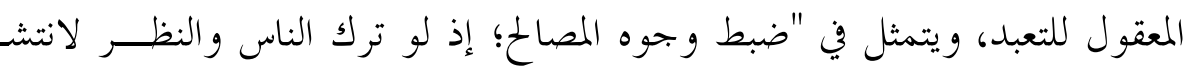

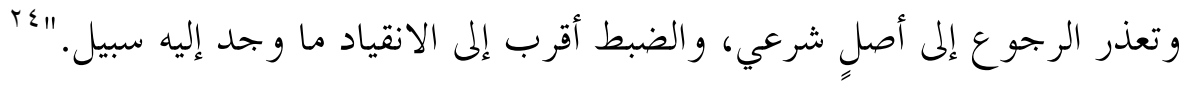

إنَّ التعبُّد منضبط بمقادير معينة، وبهيئات مضبوطة، وبشروط محددة، و بكيفيــات

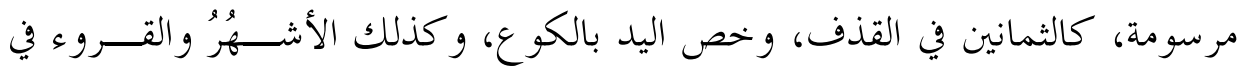

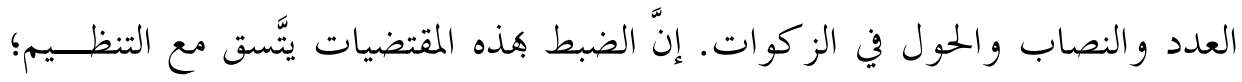

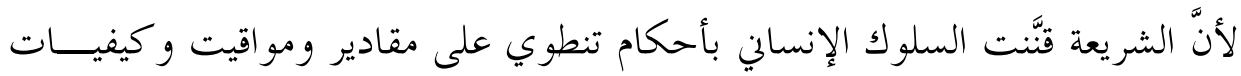
خصوصة، شأها في ذلك شأن كل الشرائع والقو انين.

لا يتناقض مقصد الضبط و التنظيم مع المعقولية؛ لأنَّ أوَّل مبدأ من مبادئ العقــل هو النظام، أعني تنظيم التعبد والانقياد لصاحب الشرع، وتلك هي أمُُّ المصالح التي تبرز

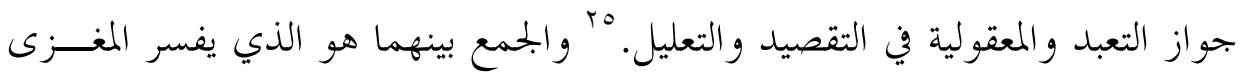

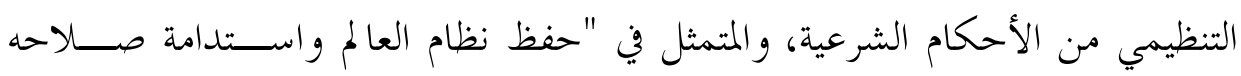

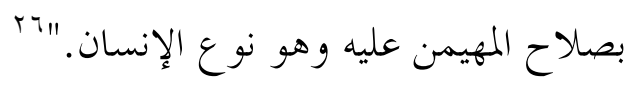

إنَّ البعد التنظيمي بُعد أساسي في مقاصد الشريعة؛ لأنَّ التجربة الحضارية للبشرية

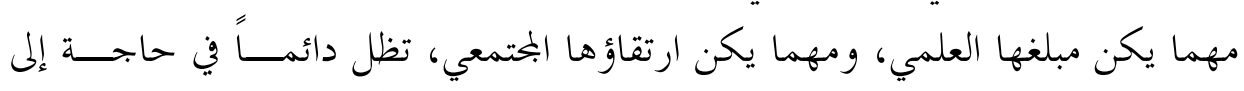

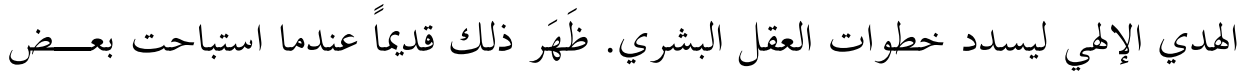

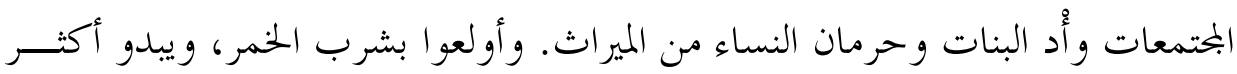

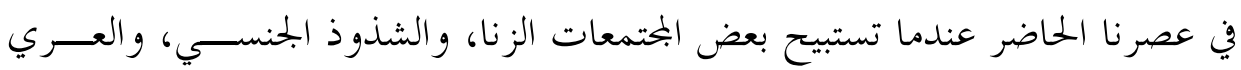

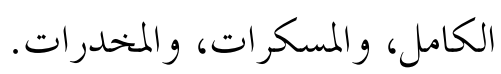

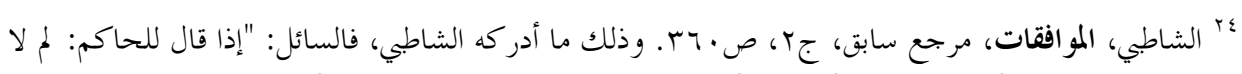

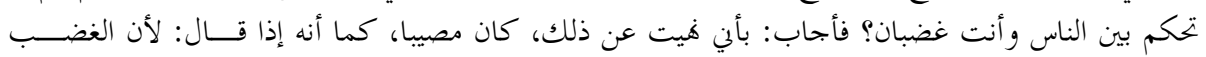

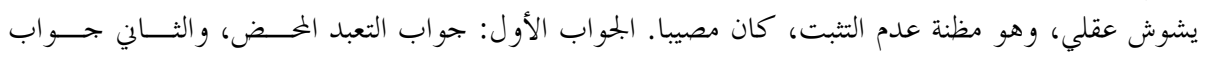

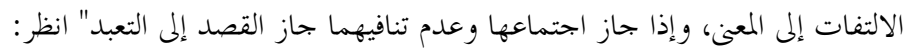

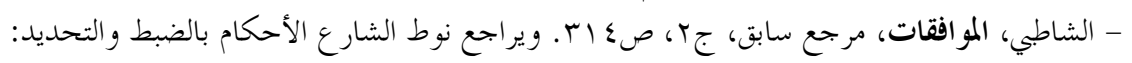

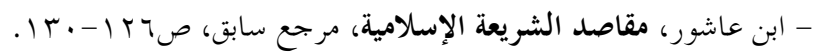

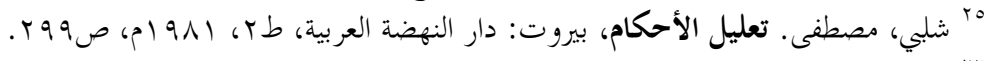

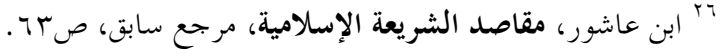




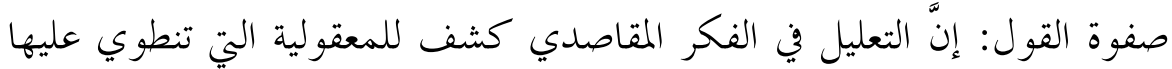
الأحكام الشرعية. ويتضمن هذا الكشف أبعاداً ثلاثة:

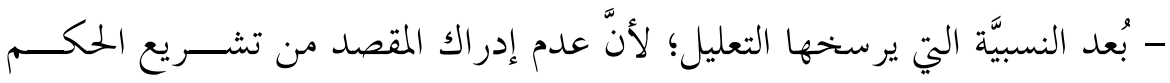

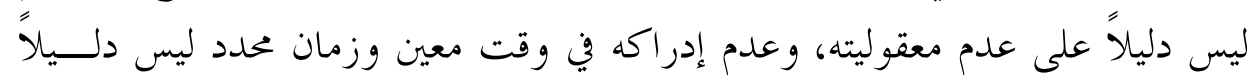

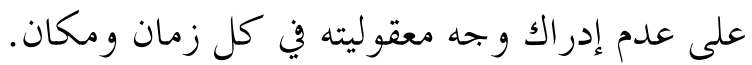

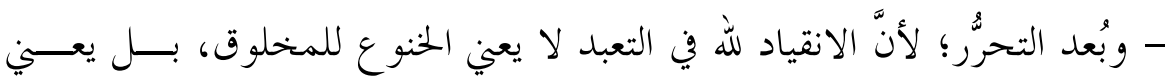

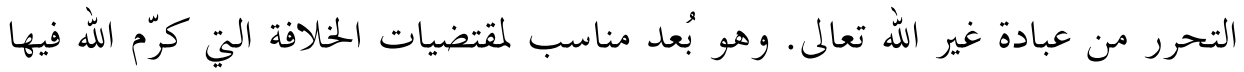

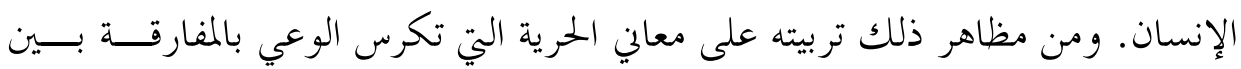

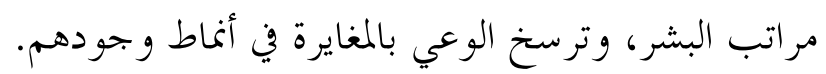

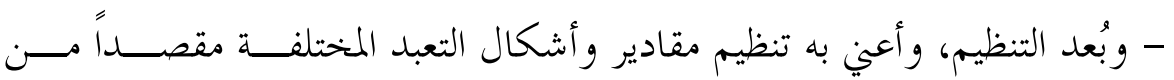

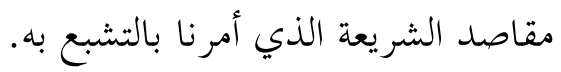

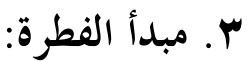

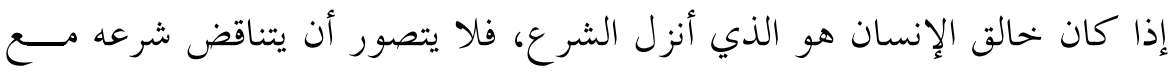

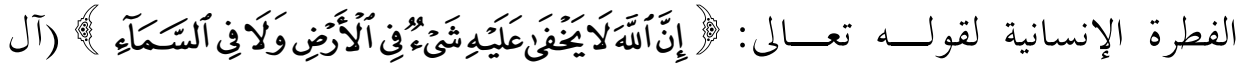

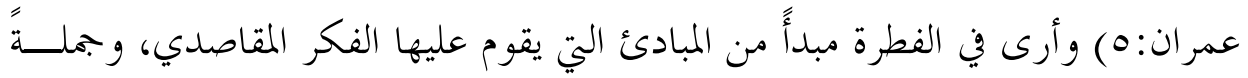

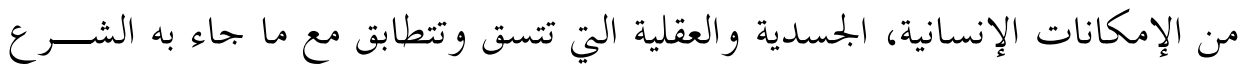

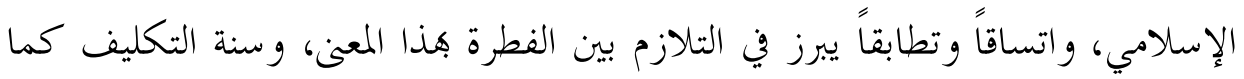

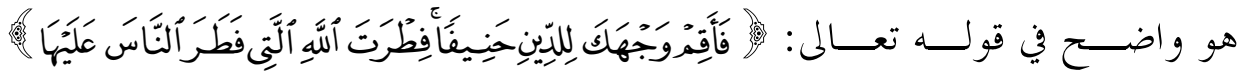

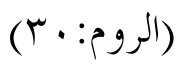

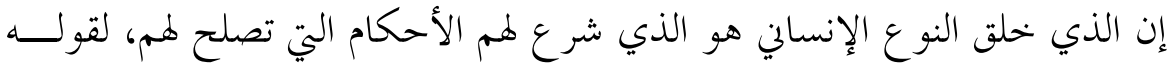

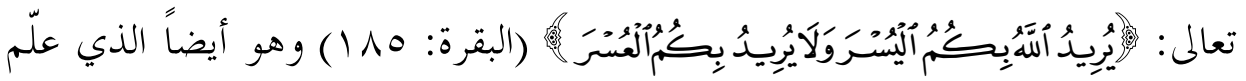

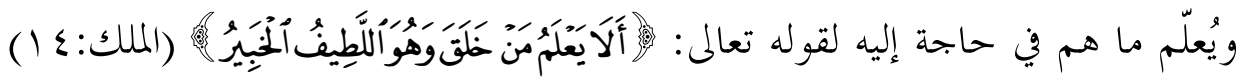

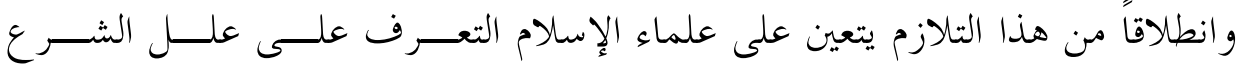


و مقاصده، ظاهرها و خفيها، فإن بعض العلل قد يكون خفياً. لقد سبق للإمـــام ابــن

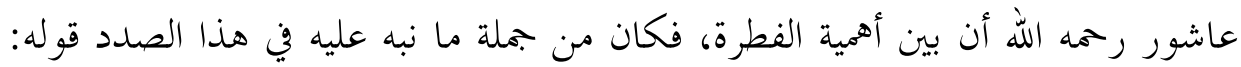

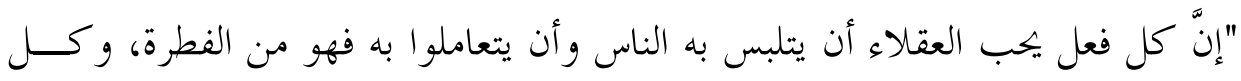
فعل يكرهون أن يقابلوا به ويشمئزون من مشاهدته و انتشاره فهو انخر اف عن الفطرة.

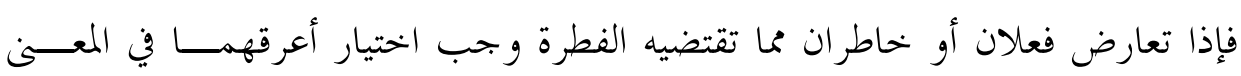

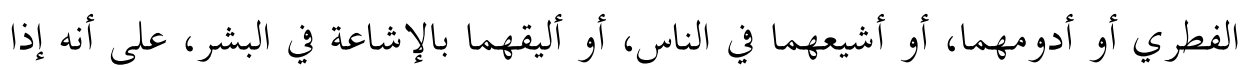

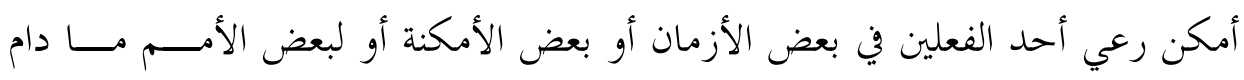

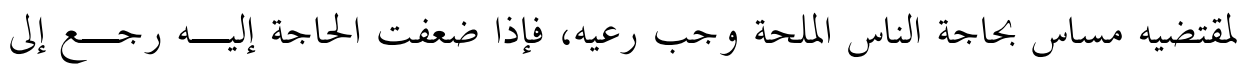
غيره.

ينهل الفكر المقاصدي من هذا المبدأ الفطري، وعلى قدر اتساق الفعل أو التصرف

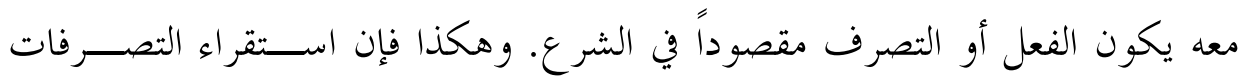

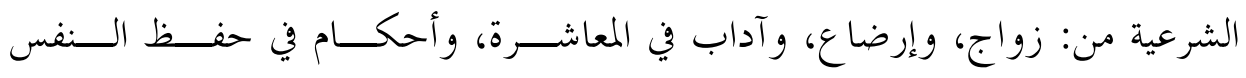

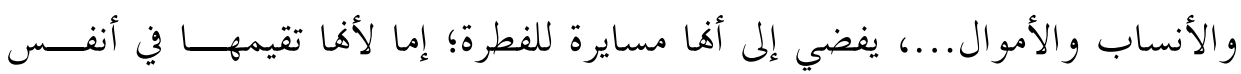

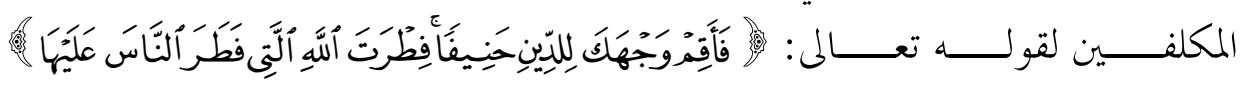

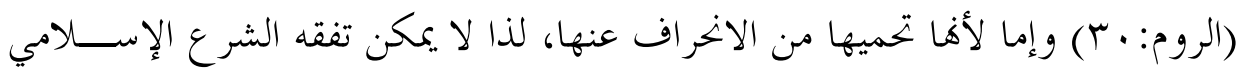

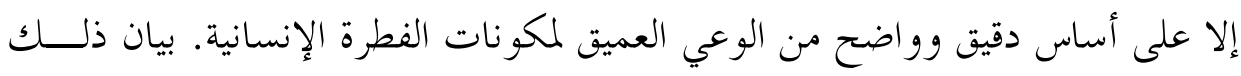

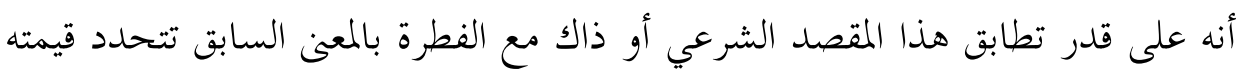

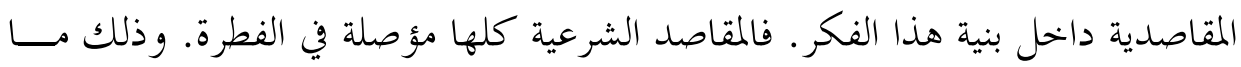

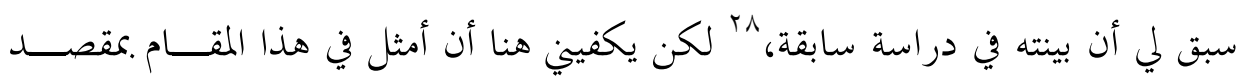

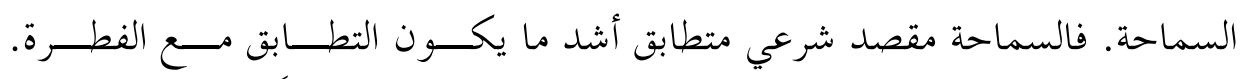

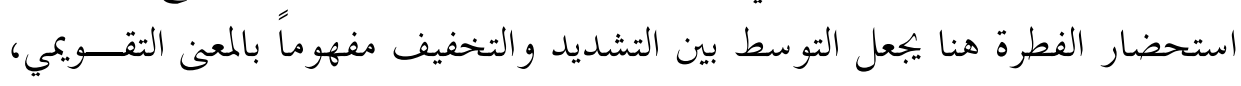

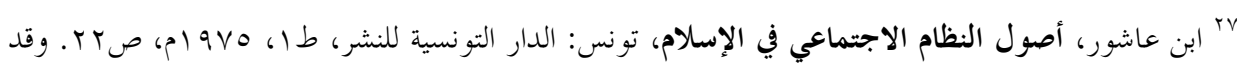

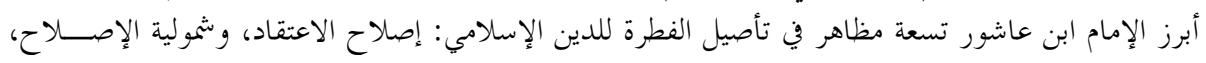

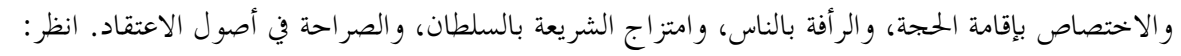

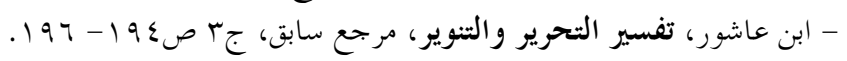

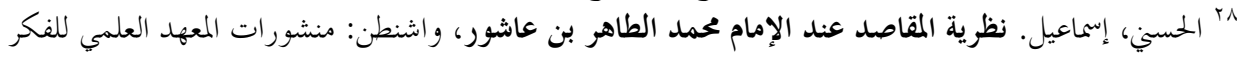

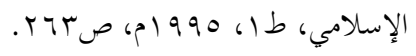




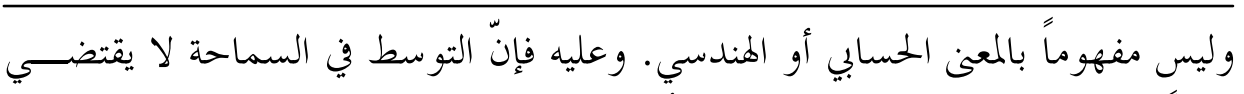

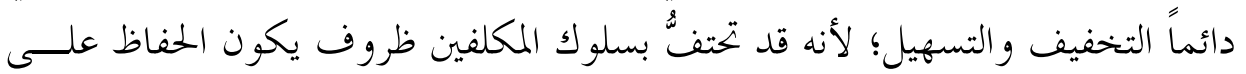

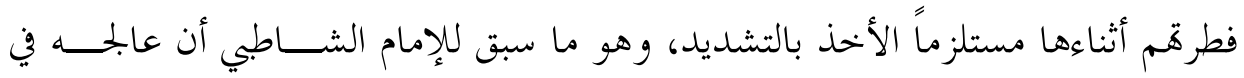

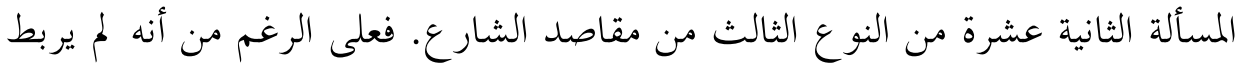

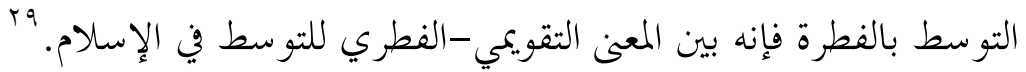

\section{ثانياً: تقنيات الفكر المقاصدي}

أعني بالتقنيات الأدوات التي تعتمد في أي بحث علمــي كالاســتقراء، واعتبــــار

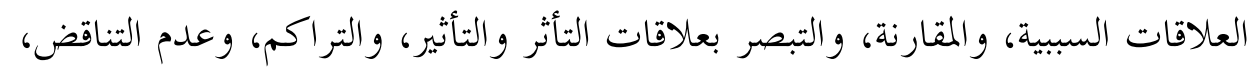

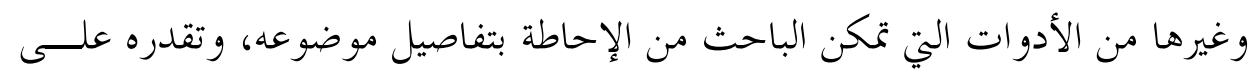
استيعاب جزئياته. ويتجسد دور هذا النوع من التقنيات داخل بنية الفكر المقاصدي في اعتمادها من أجل التوصل إلى مقاصد الشريعة و البرهنة على إثباها. تتمحور تقنيات الفكر المقاصدي في الإعمال المتبصــر لأداتــين رئيسـتين: أداة استحضار المقامات المختلفة التي سيقت في جوها النصوص الشرعية. و الأداة الثانية هي

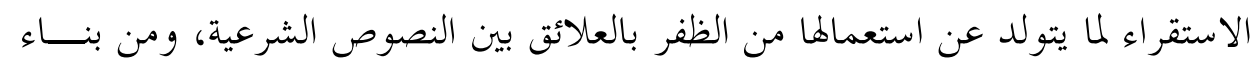
النظرة الشمولية للشريعة.

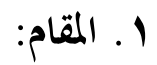

المقام هو ما يجسده روح الخطاب الشرعي ومقصده. و لا تتجسد روح الخططـاب

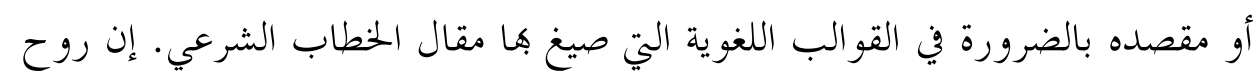

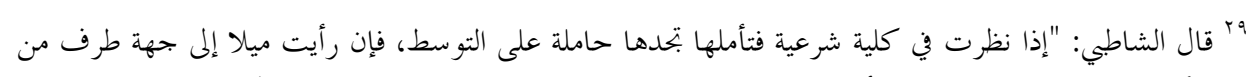

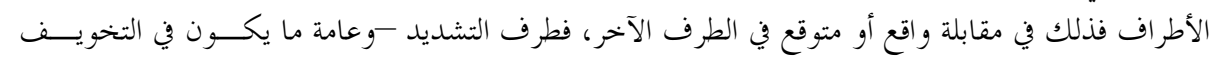

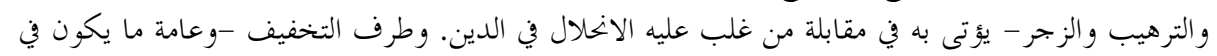

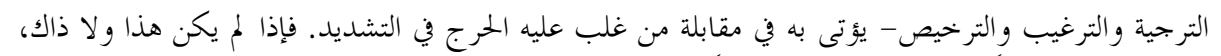

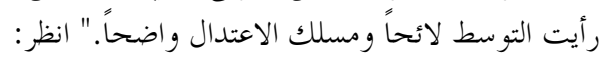

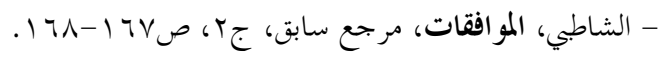




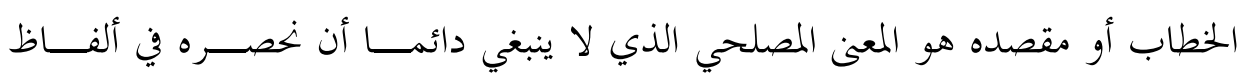

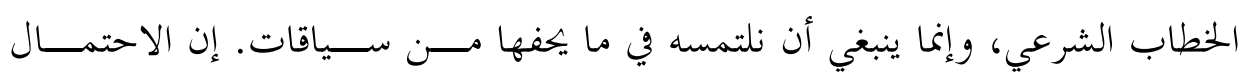

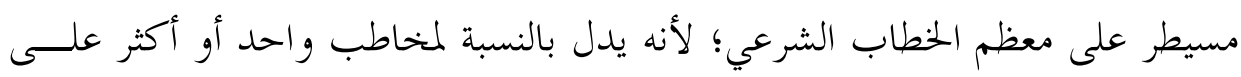

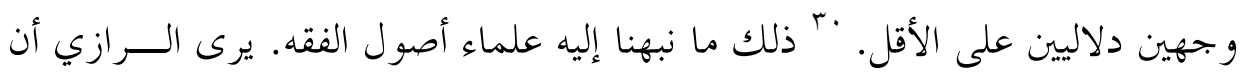

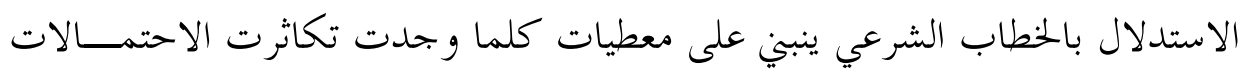

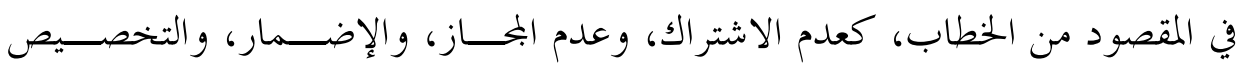
للعموم، و التقييد للمطلق،...

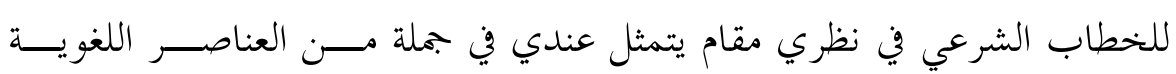

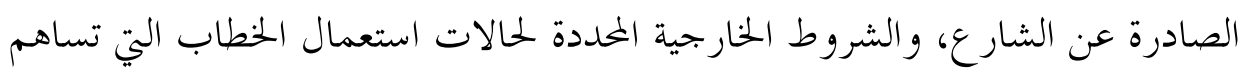

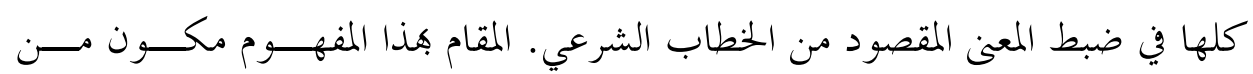

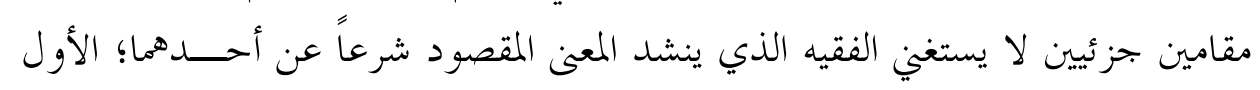

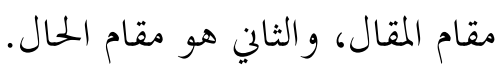

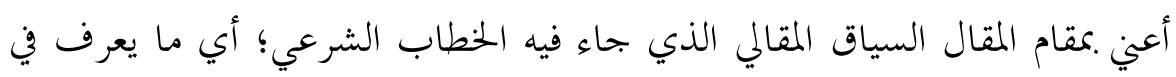

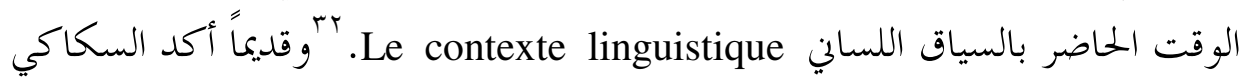
على أهمية مقام الكلمات داخل مقال الخطاب، فقال: "ثما إذا شرعت في الكابلام الكام فلكل

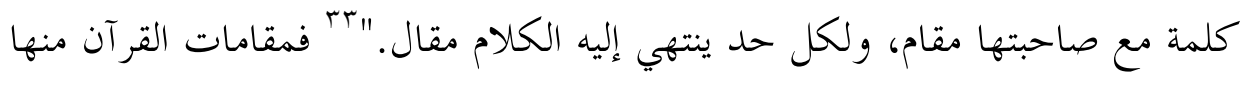

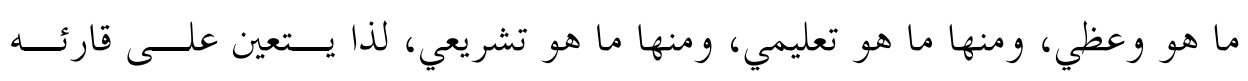
"r براجع في أسباب الاحتمال في الخطاب الشرعي:

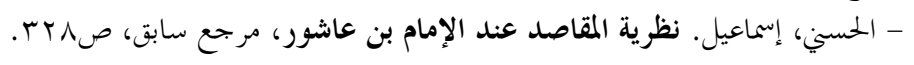
(انظر

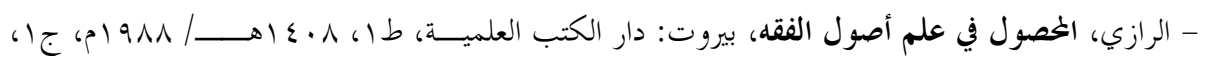

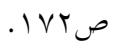

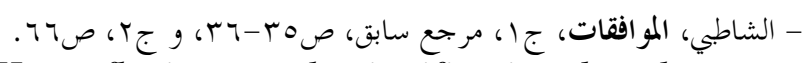
${ }^{32}$ Ahmad AlmotawakilK - reflexions sur la signification dans la pensee linguistique Arab-Rabat: Publication de la faculte des lettres- theses et memoires- N 8- p 89. 


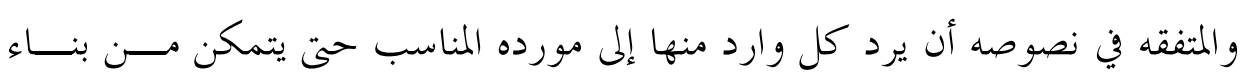

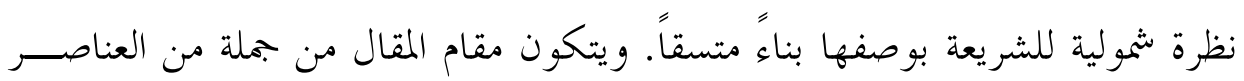

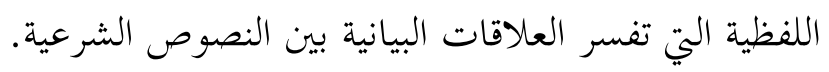

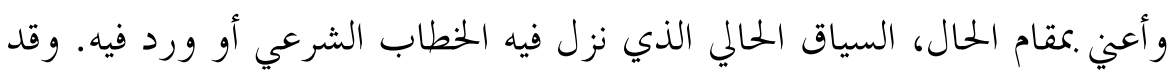

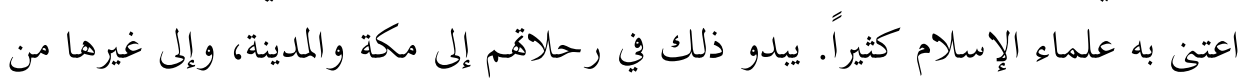

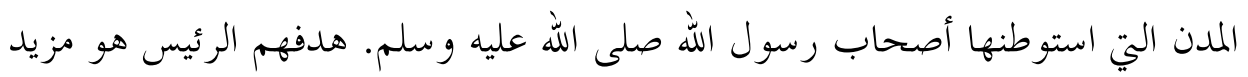

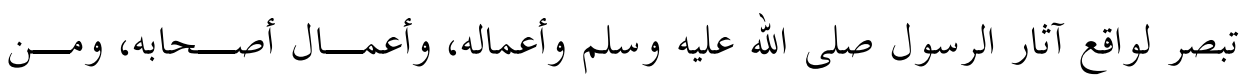

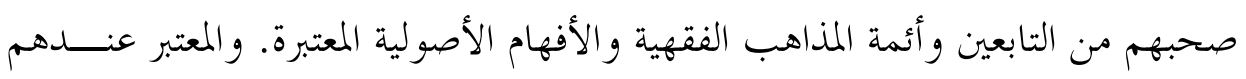

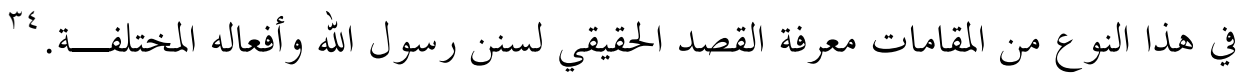

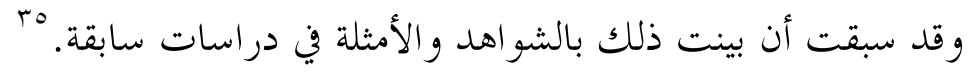

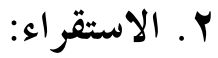

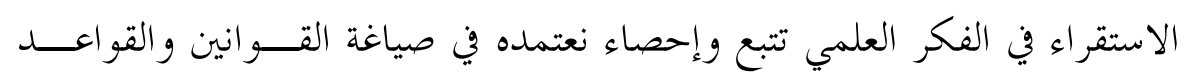

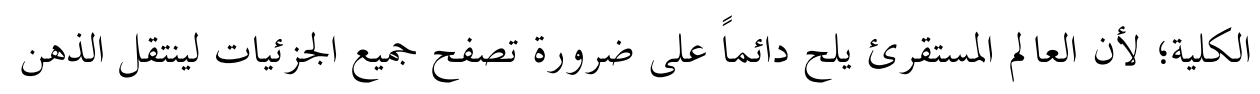

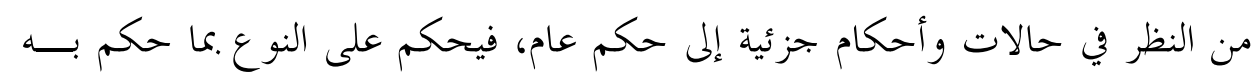

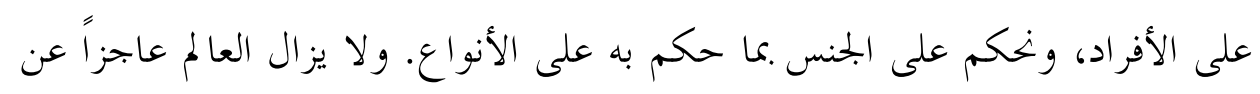

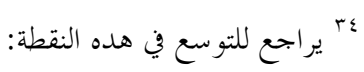

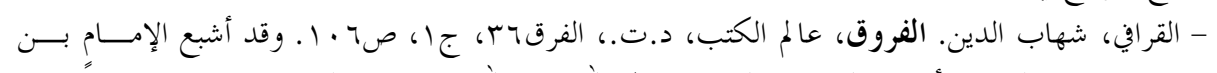

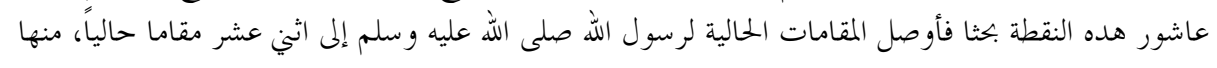

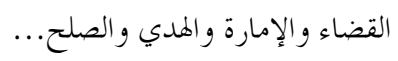
انظر

- الحسين، إسماعيل. نظرية المقاصد عند الإمام محمد الطاهر بن عاشور، مرجع سـابق، الفــل الثالــن، صTro

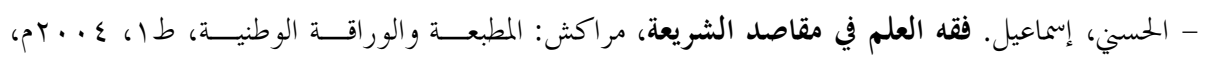

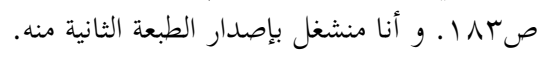

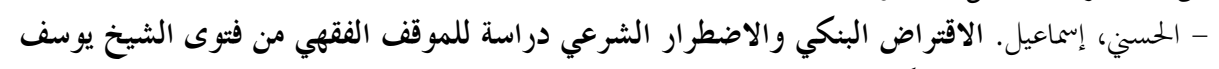

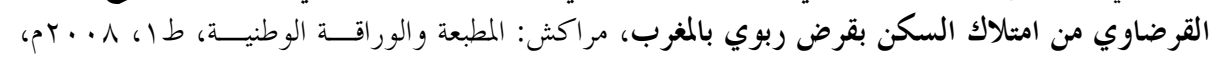
الفصل الثالث و الرابع والخامس من هذا الكتاب. 
فحص كل الأفراد؛ لأن الاستقراء مهما علت درجة التصفح و التتبع فيه يظل اســتقراء ناقصاً بالمعنى المنطقي و العلمي. لافرادي لان الإنقراء.

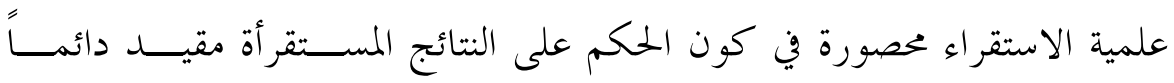

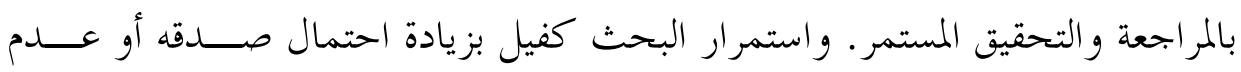

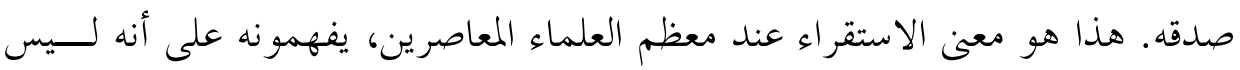

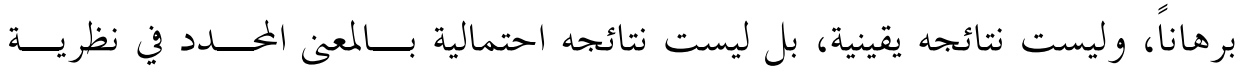

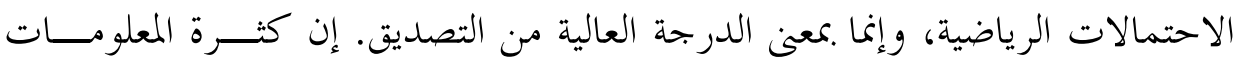

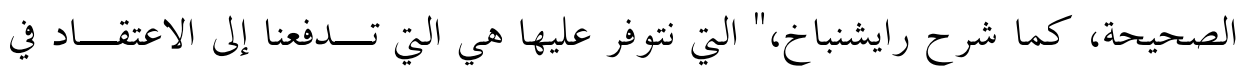

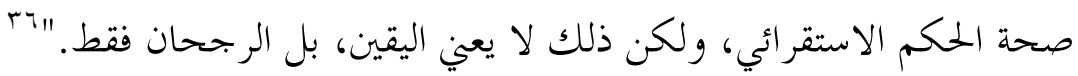
في ضوء هذا المعنى العلمي أفهم مكانة الاستقراء في الفكر المقاصدي؛ لأنه يشكل

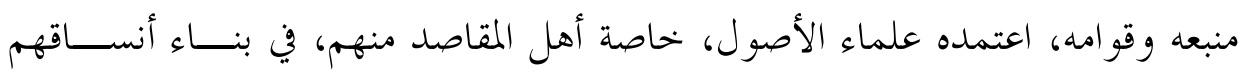

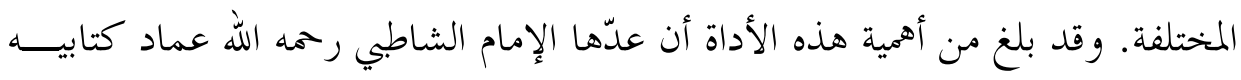

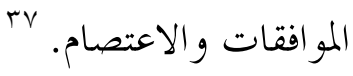

الاستقراء هو منبع ثراء وخصوبة الفكر المقاصدي في الإسلام؛ لأنه يرسخ العقلية

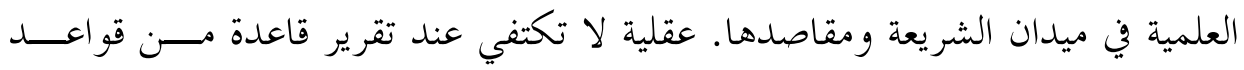

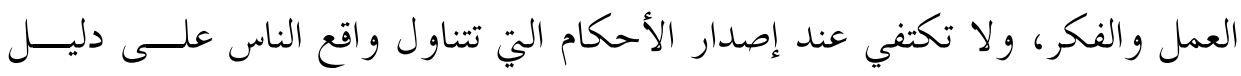

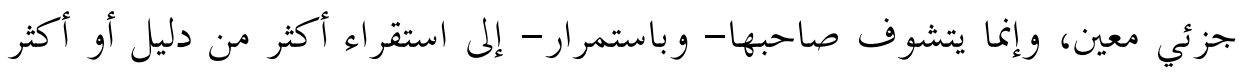
من جنس أو نوع من الدلائل.

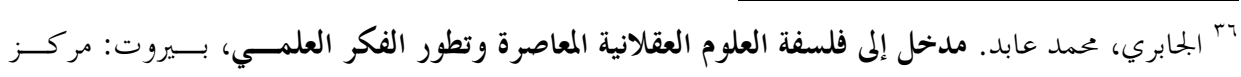

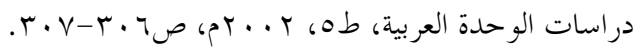

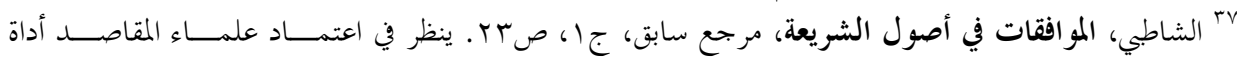

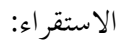
- الحسني، إسماعيل. نظرية المقاصد عند الإمام بن عاشور، مرجع سابق، صVOV وما بعده. 
الفكر المقاصدي يرسخ لفكر علمي في مستوي المبادىء، والتقنيات، وفي مستوى استخراج المفاهيم التي تحكم بنيته وتوجه منهجيته. و المفاهيم بصفة عامة أطر علميـــة

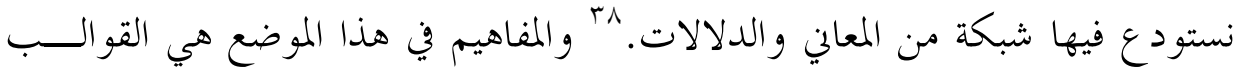
الفكرية التي ينصهر في بوتقتها النظر المقاصدي. وأقصد بذلك المعاني الكلية التي يتبلور

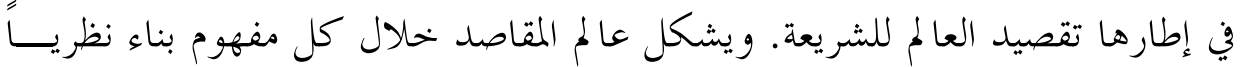
تلتحم داخله مبادئ الفطرة والفائدة و التعليل بتقنيات المقام والاستقراء. فالوصول إلى

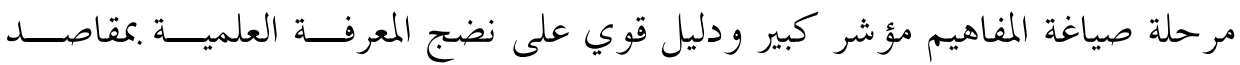

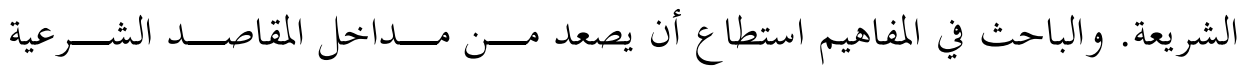

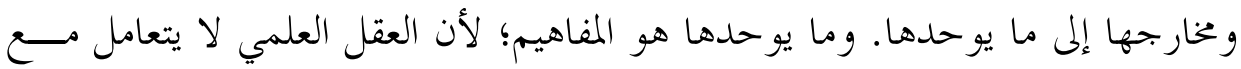

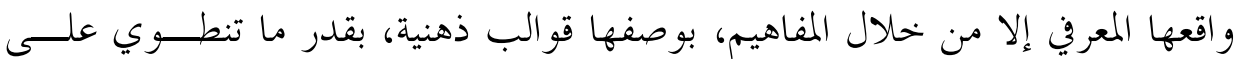

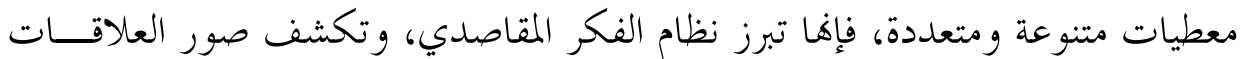

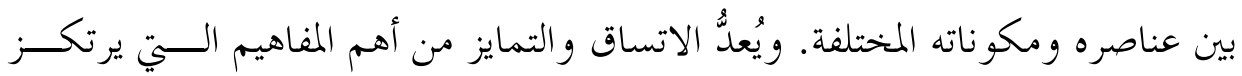

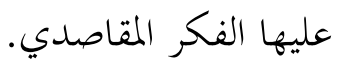

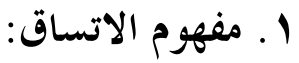

أعني بالاتساق استقامة الشريعة في ذهن الفقيه، و انتظامها في فكر البحتهد على نظام واحد غير متخالف ولا مختلف. إن الاستصلاح من جنس استدلالات الإمام مالك. نعم هذا لاشك فيه، لكن مع الحفاظ على اتساق الشريعة؛ أي "مع مراعاة مقصود الشارع أن لا يخرج عنه ولا إلا

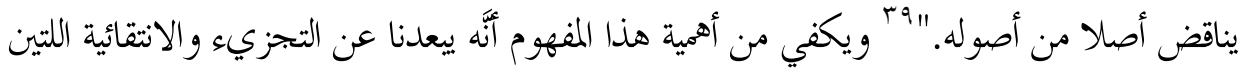

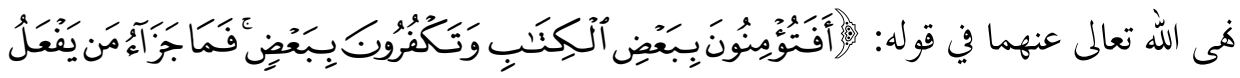

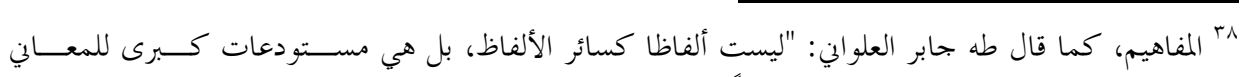

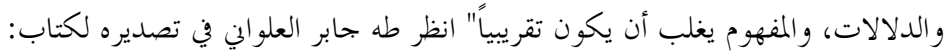

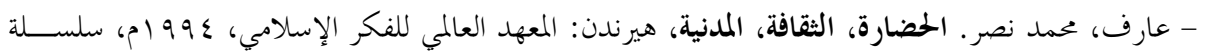

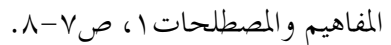

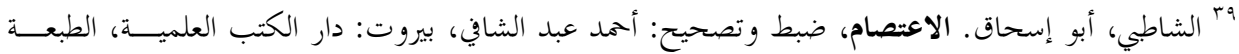




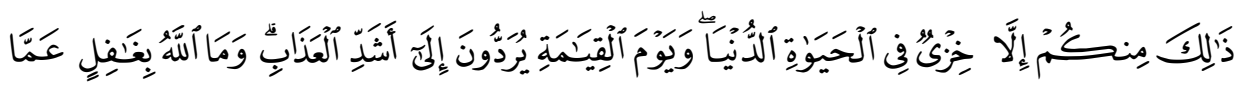

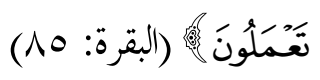

والاتساق نوعان: خارجي وداخلي. و أعبي بالاتساق الخارجي عدم تناقض الشــــيعة

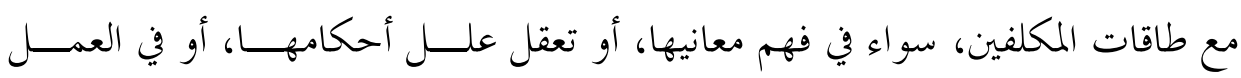
بأحكامها. فكما يضمن هذا الشطر من الاتساق تتزيه الشريعة عن التهافت، يضــــن فئن

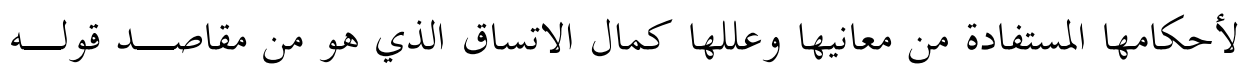

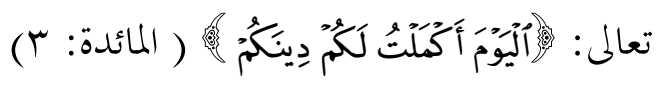

تناول الأصوليون مضمون هذا الشطر الخارجي من الاتساق في مباحث التكليف

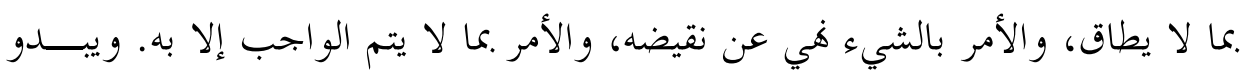

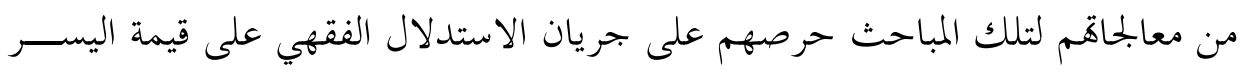

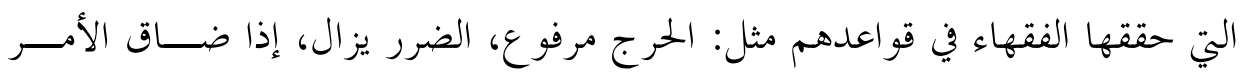
اتسع وإذا اتسع ضاق.... إذا كان في المسألة قولان فلا نأخد إلا بأيسر هما وأخفهما.

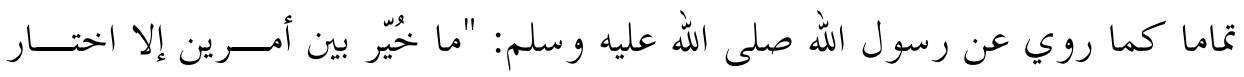

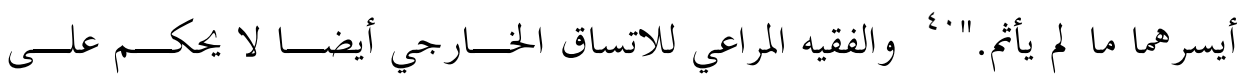
التصرفات بالحرام إلا على ما علم تحريمه جزما و وقطعا.

والحق أنه على الرغم من الأهمية المنطقية لهذا الصنف من المباحث الأصولية في ضــبط

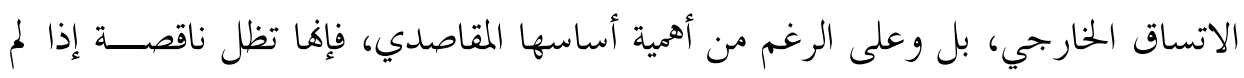

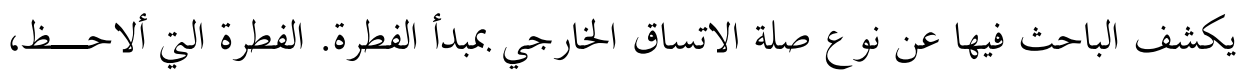

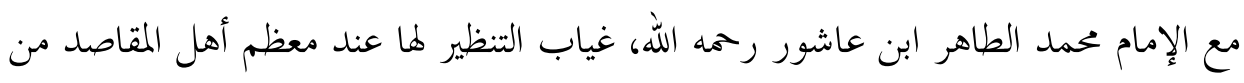

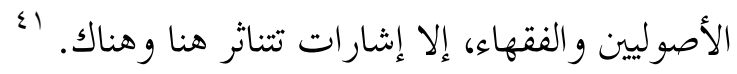

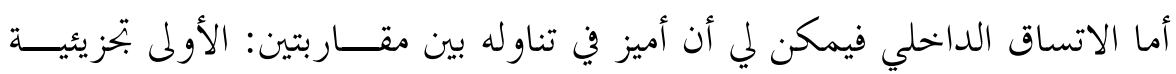
يقتصر صاحبها في بيان اتساق الشريعة على كشف الارتباطات المختلفة بين ألفاظها.

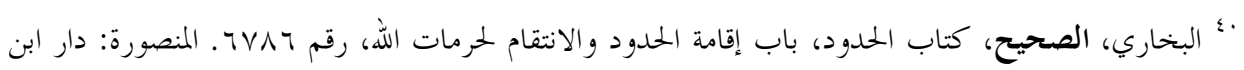

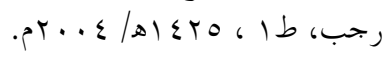

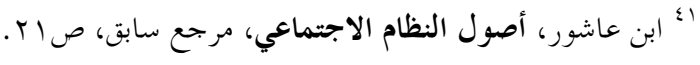


و يبدو ذلك في دفع التعارض بينها، ووي مسائل الإجمال والخفاء، و التواطؤ والاشتراك،

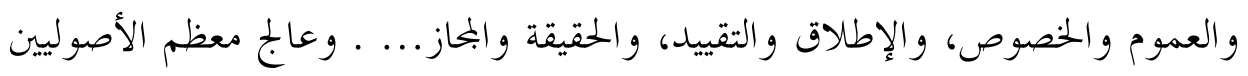
كل ذلك بمنطق لا يرتقي في الغالب إلى أفق شمولي يتبصر صاحبه بالاتساق بين ألفاظ

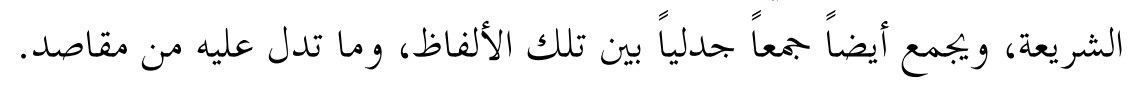

و المقاربة الثانية مقاربة شمولية للاتساق؛ إذ يشبه صـــاحبها الشــــيعة بالصـــورة

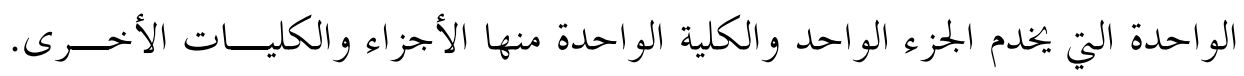
وهذذا ينطلق صاحب المقاربة الشمولية للاتساق من انتظام أحكام الشـــريعة، ودلالات ألفاظها في الكلية الواحدة. ما كتبه الشاطبي في الموافقات وفي الاعتصام من النمــاذج الجيدة في هذه المقاربة الشمولية. ذلك أنه يتصور الشريعة في صورة "الإنسان الصحيح السوي، فكما على الإنسان أن لا يكون إنساناً حتى يستنطق، فلا تنطق اليد و حدها، ولا بالرأس وحده، ولا باللسان وحده، بل بجملته التي سمي هـا الإنسان كذلك الشريعة

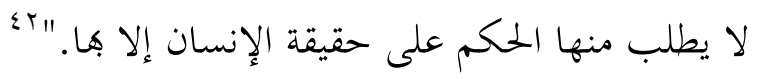

وهكذا يثمر التمسك بالاتساق في هذا السياق جملة من الفوائد، منها أن التمســك

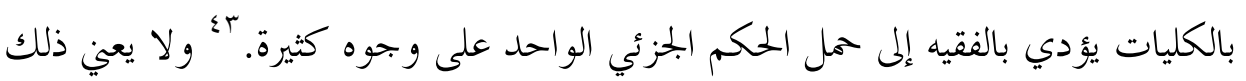

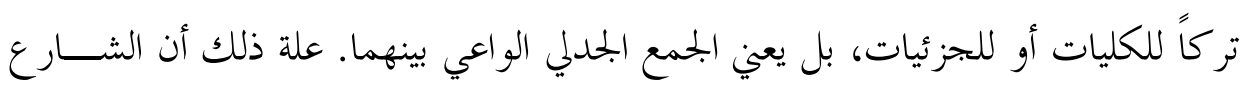
كما أوضح الشاطبي "لم ينص على ذلك الجزئي إلا مع الحفظ على تلك القواعد؛ إذ كلية هذا معلومة بعد الإحاطة بمقاصد الشريعة، فلا يمكن، والحالة هذه، أن تخرج القواعد بإلغاء

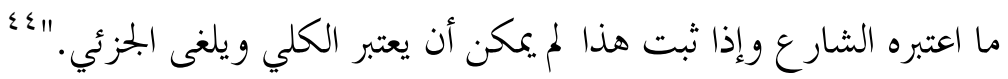

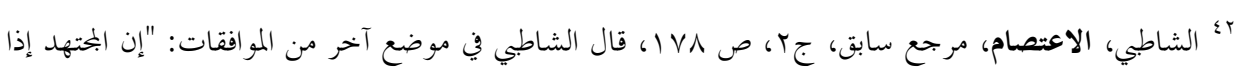

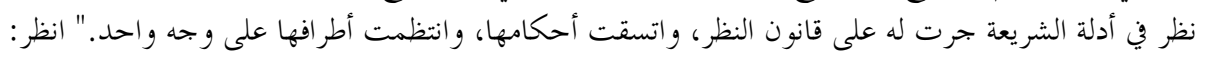

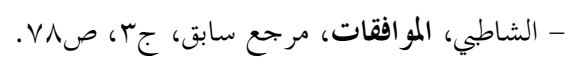

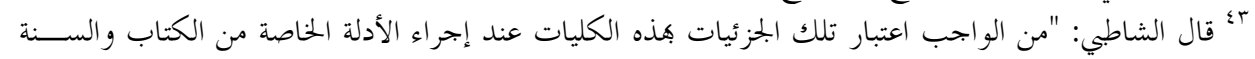

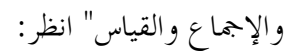

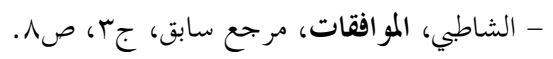

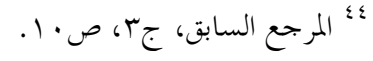




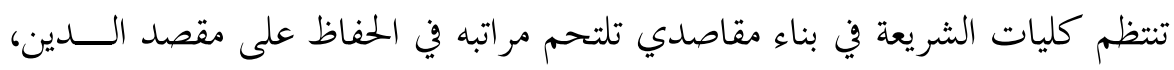

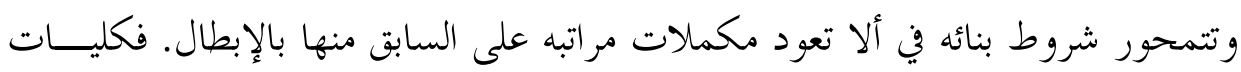

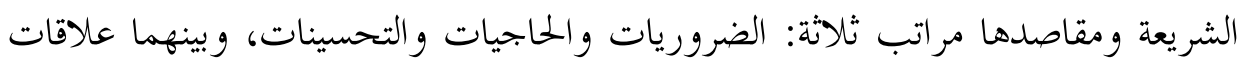

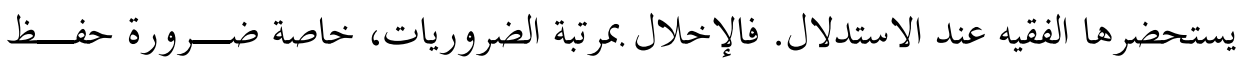

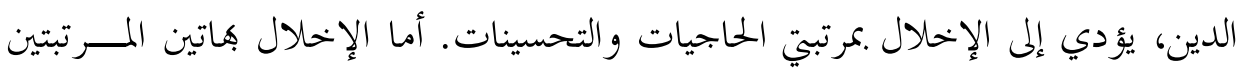

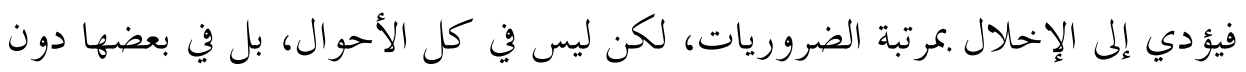

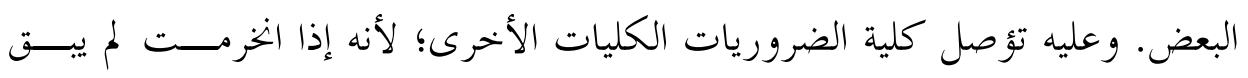

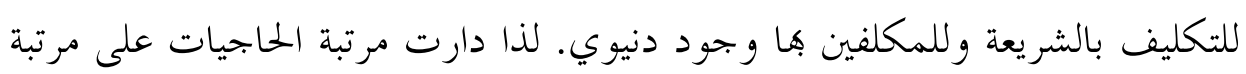

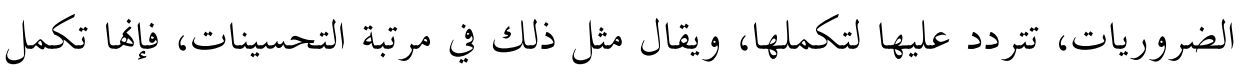
ما هو من مرتبة الحاجيات أو الضروريات، فهي كالفرد عليهات للأصل ومبني عليه. عدم اعتبار هذا النوع من العلاقة بين مراتب كليات الشريعة يؤدي إلى الاخسـتلال.

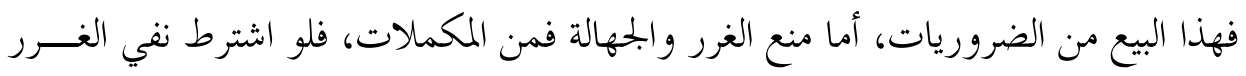

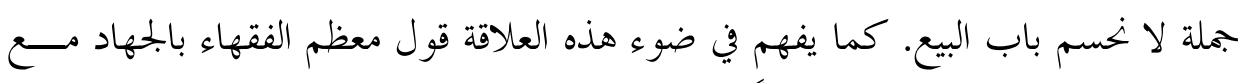

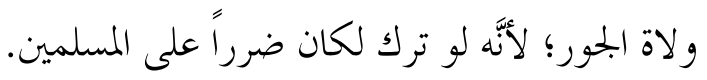

وصفوة القول: إنَّ القول بالاتساق في الشريعة قاسم مشترك بين الجميع؛ لأنَّه مبــــأ

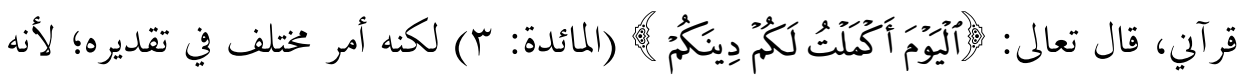

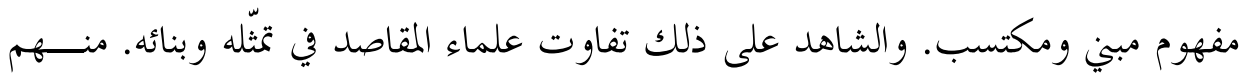
من طرحه طرحاً بجزيئياً، ومنهم من ارتقى إلى طرحه طرحاً شمولياً.

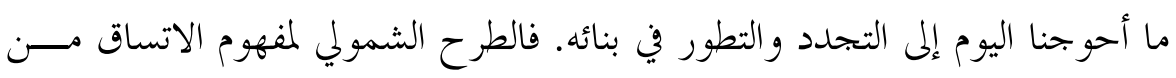

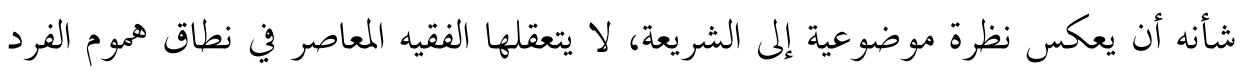

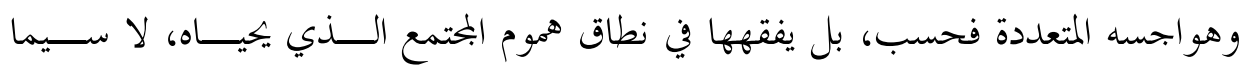

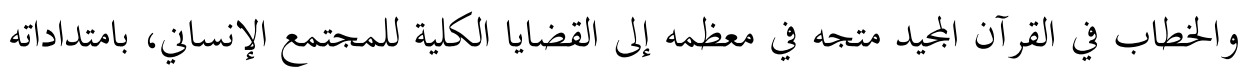

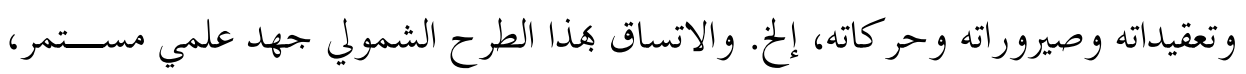

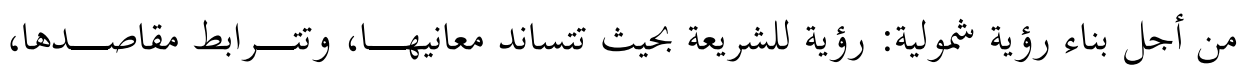




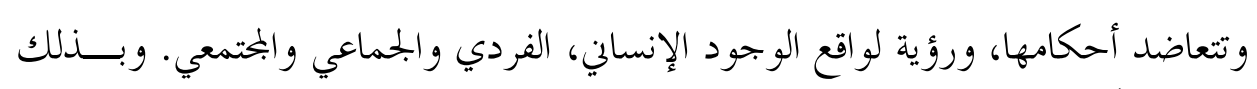

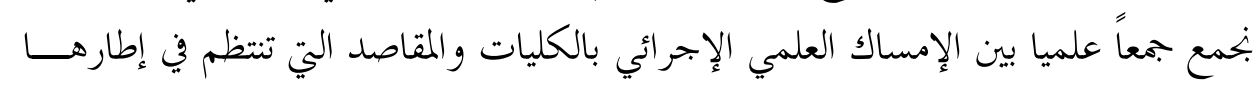

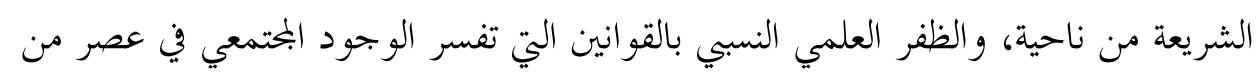
العصور من ناحية ثانية.

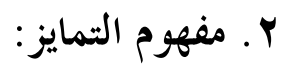

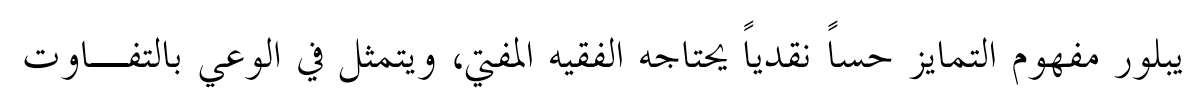

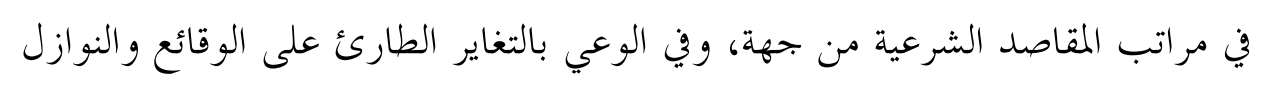
من جهة أخرى.

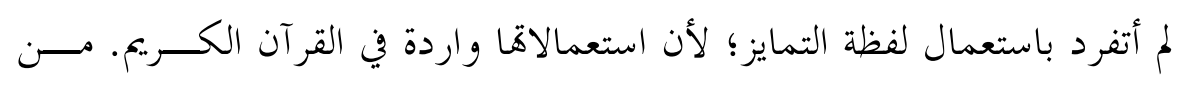

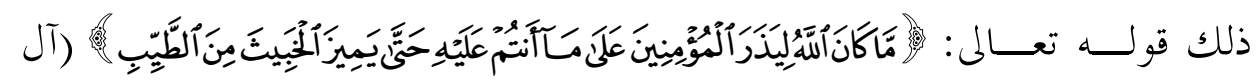

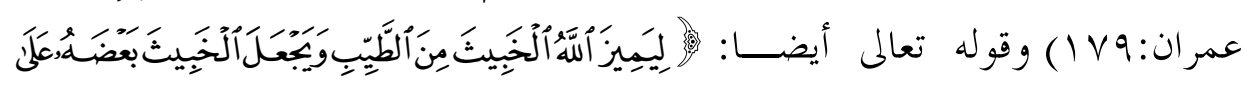

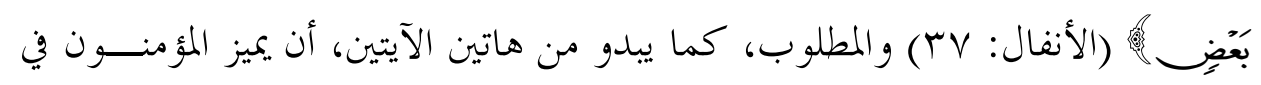
مراتب الناس وفي أحو الهم، وفي أوضاعهم ليكون المؤمنون على بصيرة من أمرهم.

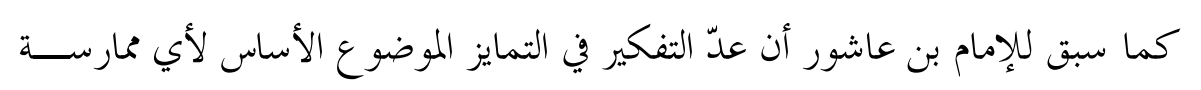

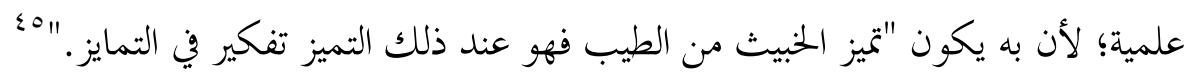

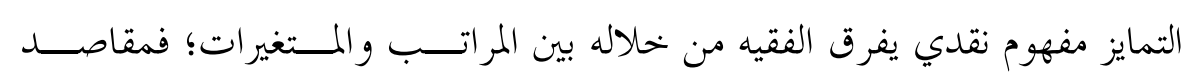

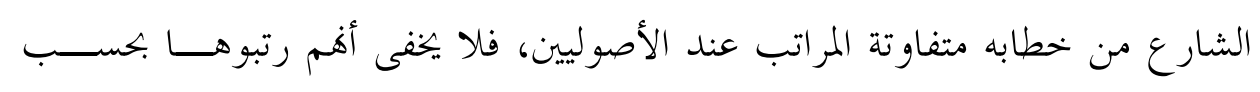

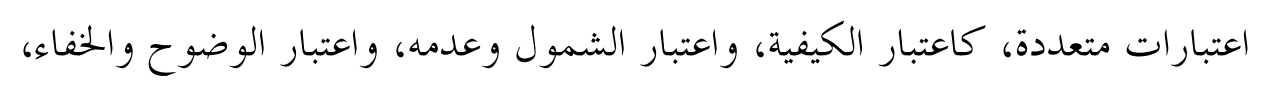

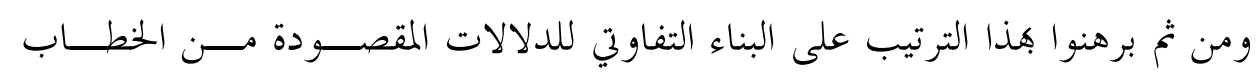

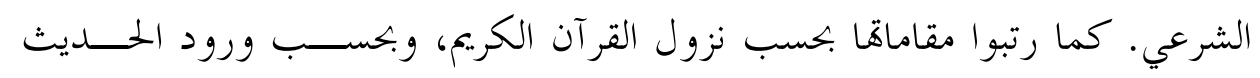

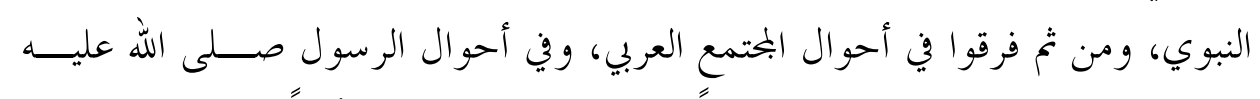

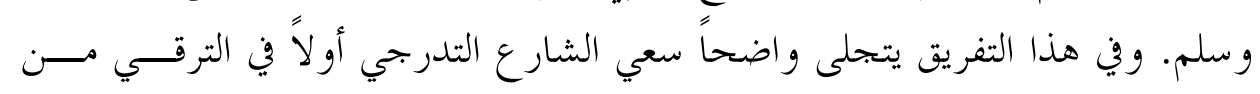




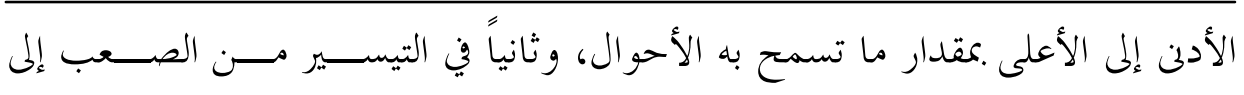
الأصعب.

وفي نظري يشكل التبصر بالمراتب في مقاصد الخطاب الشرعي بما يعنيه من وعي

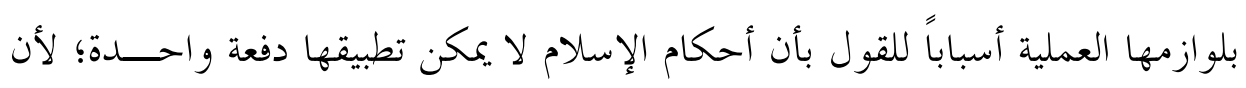
الناس منازل في العمل في مندوباها ومباحاةا وفي الكف عن مكروهاها. و لأن تغــاير أحو الهم قد يؤدي هـم إلى الوقوع، كما قال الأستاذ علال الفاسي: "في حالة شــبيهة

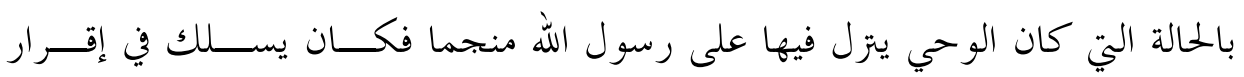

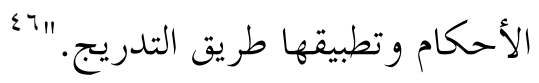

أما مقاصد الشارع من أحكامه، فتنقسم إلى مرتبتين:

- مرتبة الغايات أو المقاصد الجزئية، وهي العلل التي استهدفها الشارع في تشريعه لكل حكم من الأحكام الشرعية. وهي مراتب يمكن ترتيبها حسب الوضوح و الحفناء، و القطع و الظن، و الموقع من الحكم، ومدى الانضباط.

- و ومرتبة الغايات أو المقاصد الكلية الذي تحدث عنها الأصســـليون في مبحـــث المصلحة ضمن مباحث القياس، ومباحث الأدلة الشرعية. ويمكن ترتيبها وَفق اعتبارات معرفية، و بحتمعية. ومن زاوية الترتيب المعرفي فالمقاصد مراتب ثلاث:

مرتبة المقاصد القطعية، منصوصة كانت أو غير منصوصة، ثابتة باستقراء أحســوال

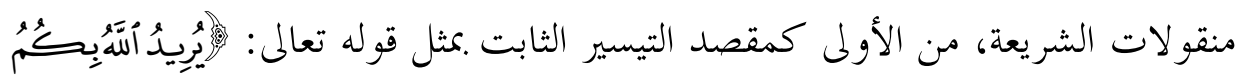

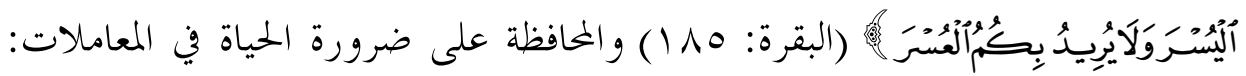
فضلا عن حفظ حاجياةا وتحسينياتا. 


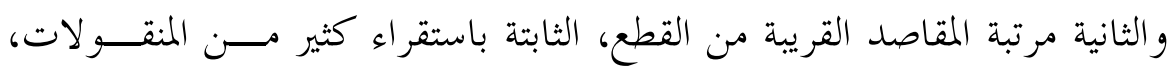

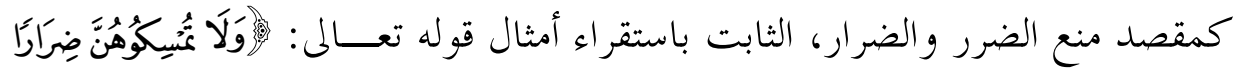

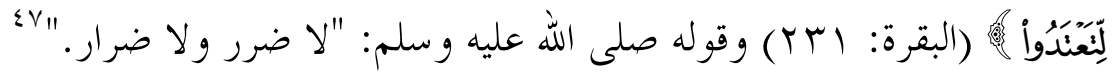

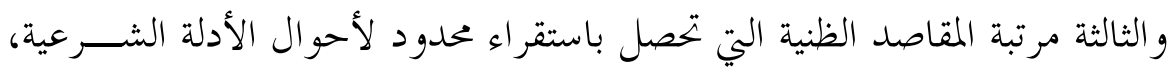

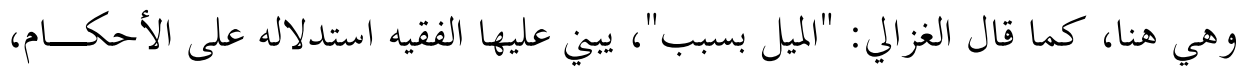

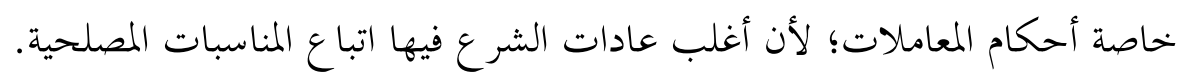
وتظهر المقاصد من خلال الاعتبار المختمعي مرتسمة في ثلاث مراتب: الضروريات: تؤسس مرتبة الضروريات نظام الوجود البختمعي، وتشمل ضـــروريات

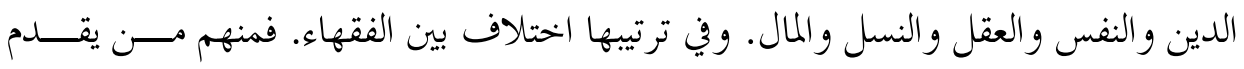

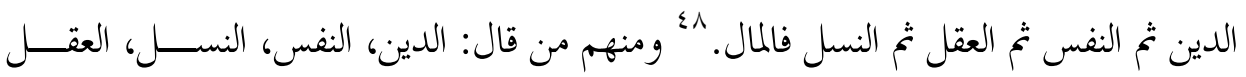

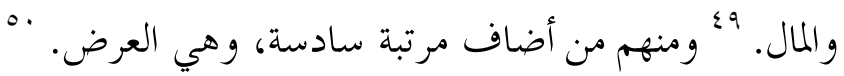

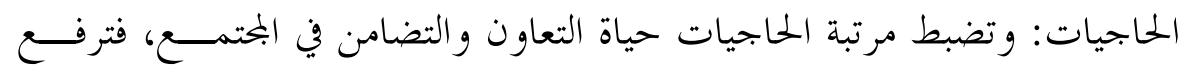

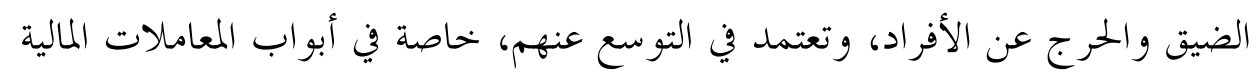
كالقر اض و المساقات و السلم وسائر أحكام البيوع عالمباحة.

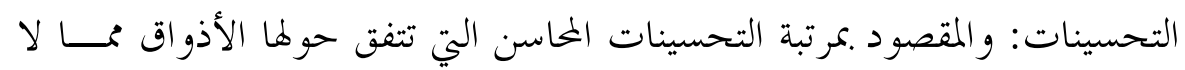

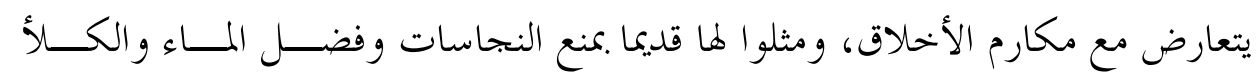

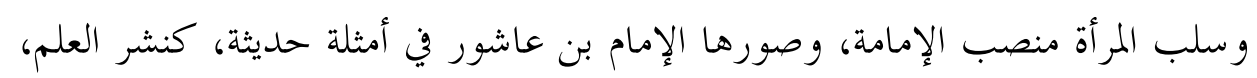
وإيجاد الملاجئ، والمنتز هات.

Vاءمالك بن أنس، الموطأ، تحقيق: الشيخ طه عبد الرؤوف سعد، القاهرة: المكتبة الأزهرية، كتاب الأقضية، بــاب

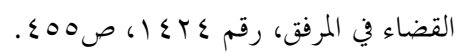

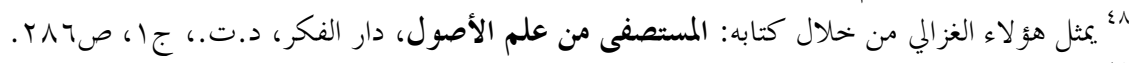

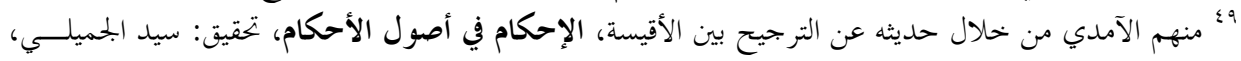

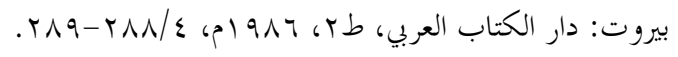

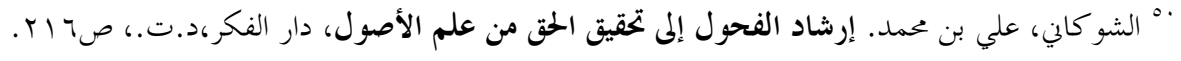


لا طريق إلى هذه المرتبة إلا إذا انطلقنا من استحضار مقصدين: مقصد الســماحة

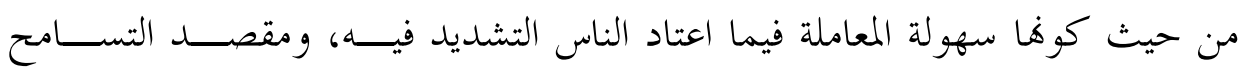
كسلوك أخلاقي في تلقي مفارقات الغير بالصدر الرحب، و اللسان الطلق، و التعـايش

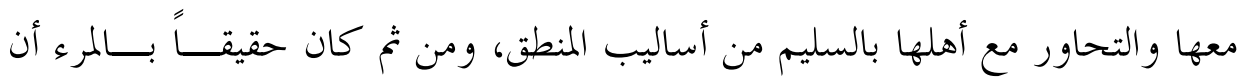

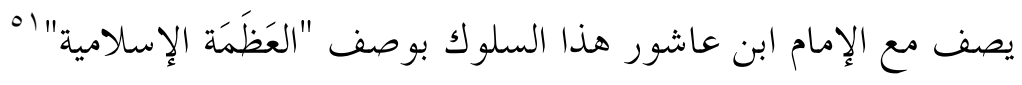

لا يتحدد مفهوم التمايز في بجرد التمييز بين المراتب، وإنما يمتد إلى الوعي بالتغــاير

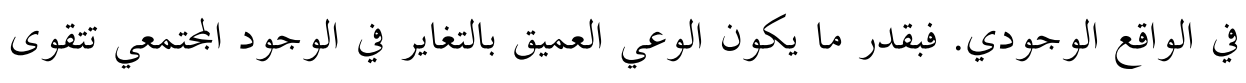

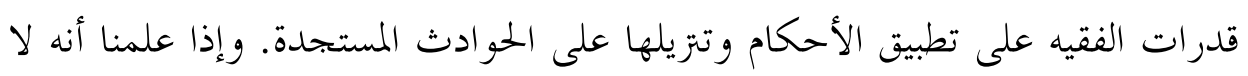

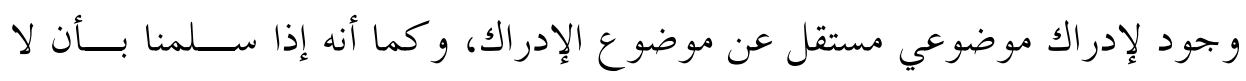

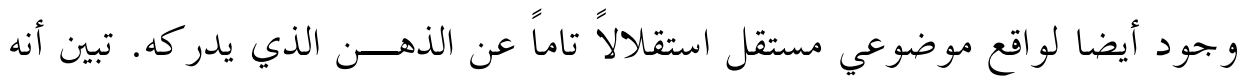
لا مشروعية لأي استنباط فقهي، و لا لأي فهم فكري دون الوعي بأشكال المغايرة في الوجود الدنيوي، من: مقابلة ومفارقة ومخالفة... . لقد أعمل فقهاء الإسلام الأفذاذ هذا الوعي أثناء فقهرم للمتغيرات، ابتداء مــــ

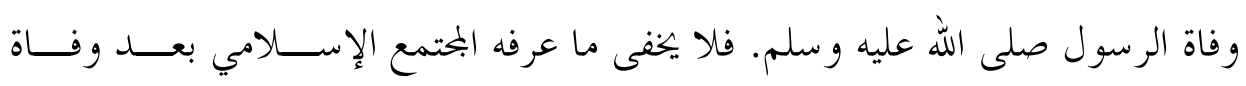
الرسول من متغيرات عميقة. فنازلة موته أدت بالصحابة إلى النظر في مسألة خلافتــهـ.

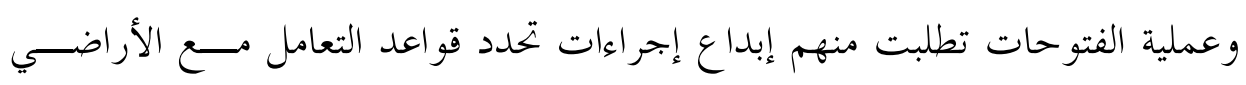

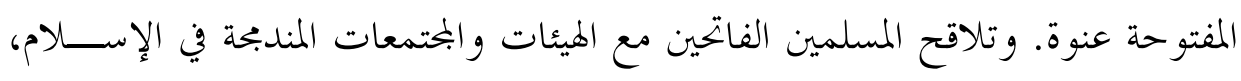

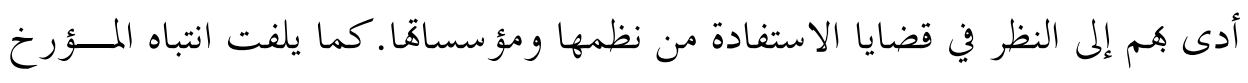

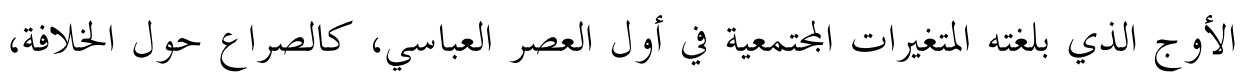

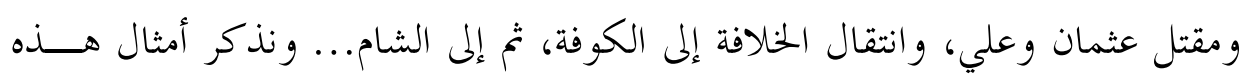

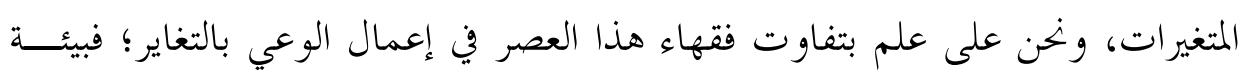
المدينة، على سبيل المثال، لم تعرف من المتغيرات ما عرفته البيئة العراقية. 


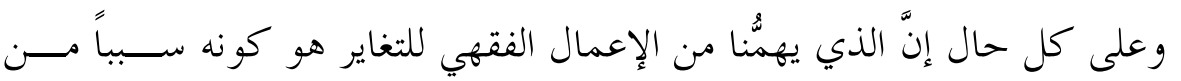

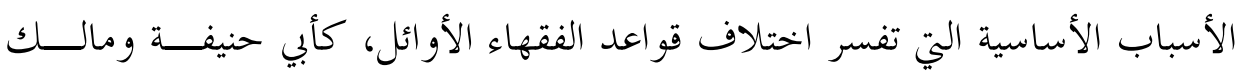

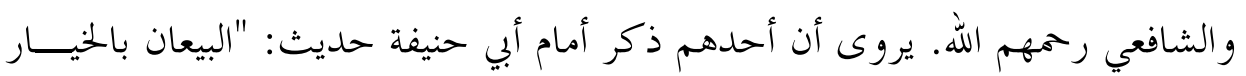

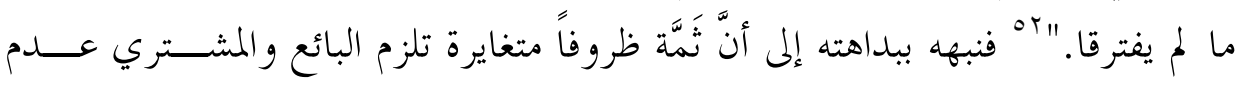

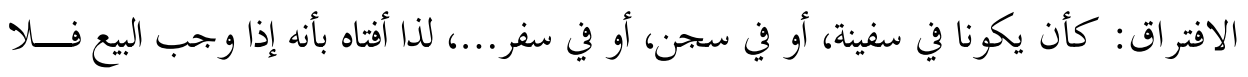

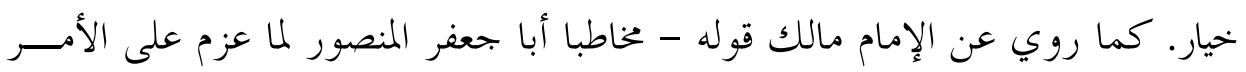

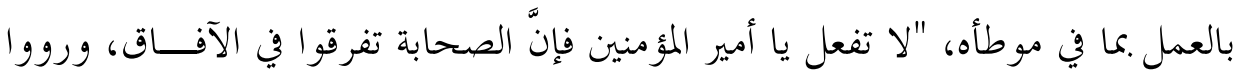

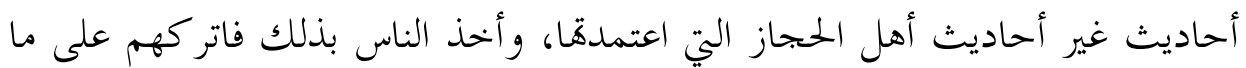
هم عليه." أحاديث غرئ

يستشف من هذا القول المالكي خاصية التسامح مع المختلفين. ومنشؤها الــوعي

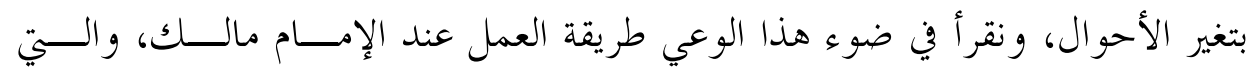

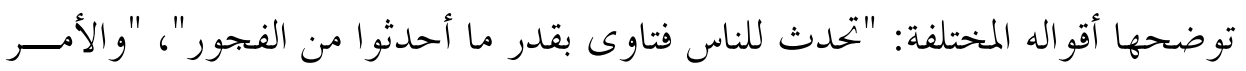

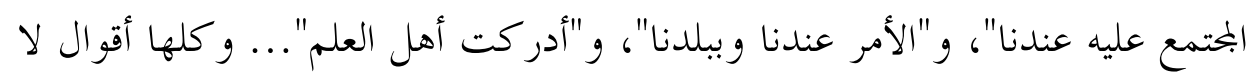

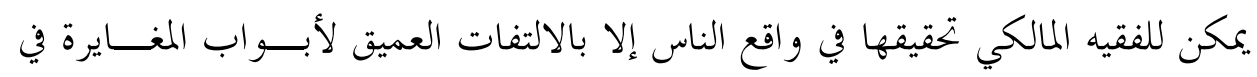

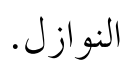

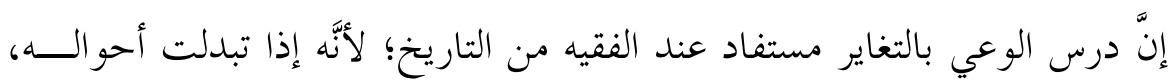

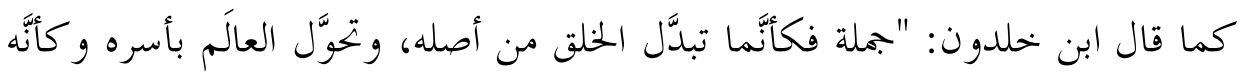

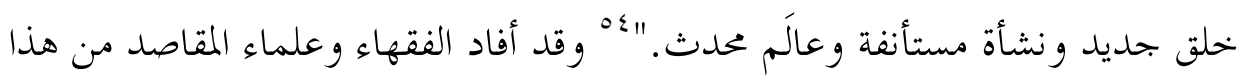

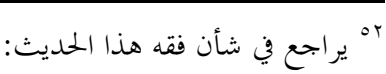

- ابن عاشور، حممد الطاهر . كشف المغطى عن المعاني والألفاظ الواقعة في الموطأ، تونس: الشر كة التونسـية

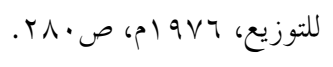

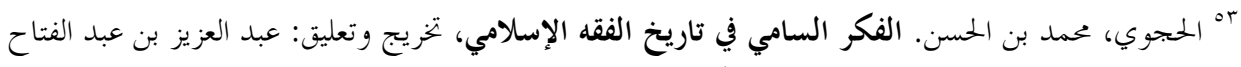

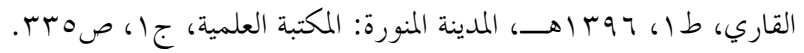

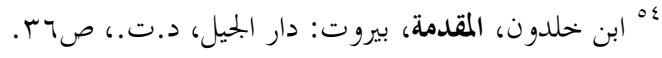




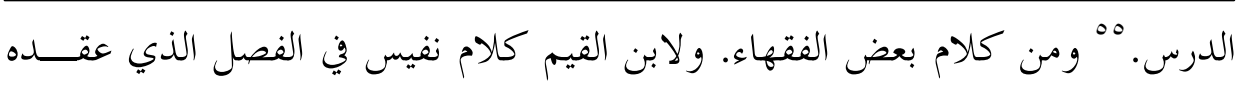
في تغير الفتوى واختلافها بحسب تغير الأزمنة والأمكنة و الأحو ال و النيات و العو ائد. و يكفي أن ألمح في هذا الباب إلى أنَّ الوعي بالتغاير عنصر أساسي من العناصـــر المعرفية التي تفسر فرادة الفكر المقاصدي لإمام الشاطبي وغناه. و يبدو ذلك الك على الأقل في مظهرين:

الأول: جمعه الدقيق بين التجريد و التنــزيل في تصور الفعل التكليفي الذي يتوجه عليه قصد الشارع من خطابه وأحكامه؛ إذ يفرق الشاطبي في هذا المظهر بين تصورين

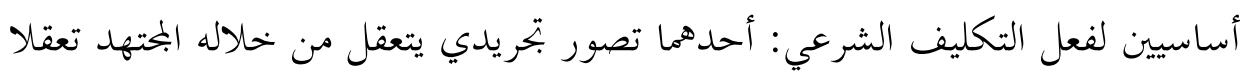

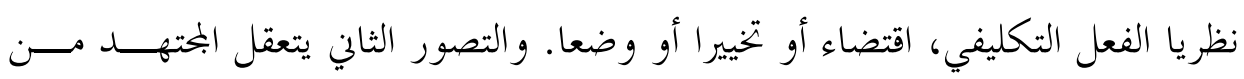

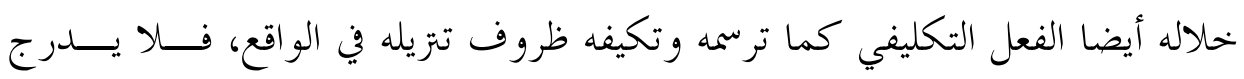

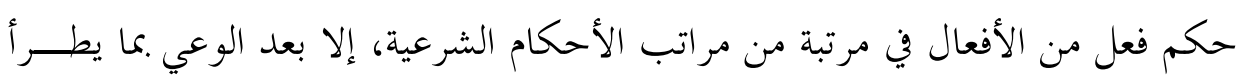

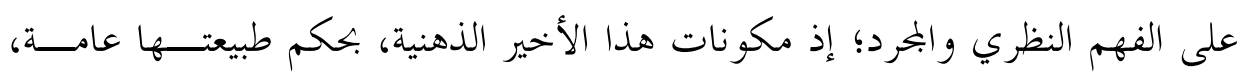

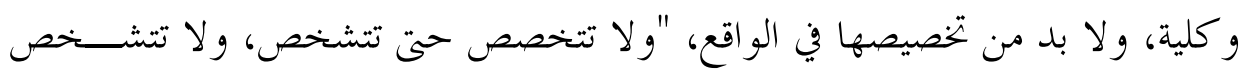

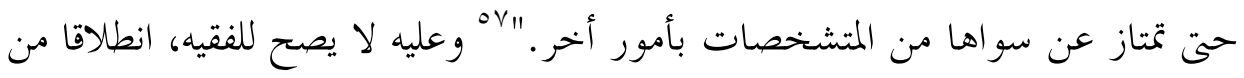

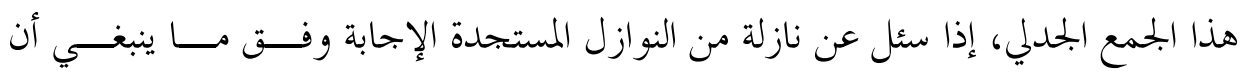
يكون، بل يجب عليه أيضا الإجابة تبعا لما هو كائن. وطريق ذلك التبصر بكيفية حصـــول التهول

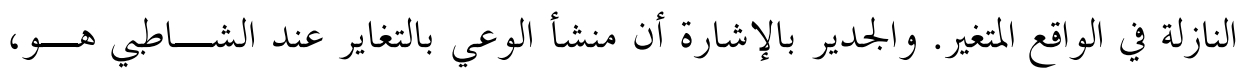
بالإضافة إلى إطلاعه العلمي الواسع، انخراطه العملي في خطط العدالة والإمامة وغيرها

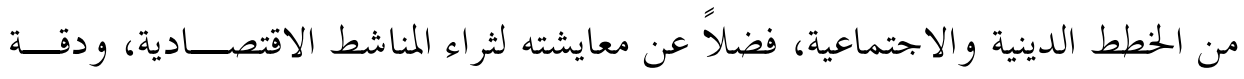
الأوضاع الأمنية لبيئة غرناطة في عهده.

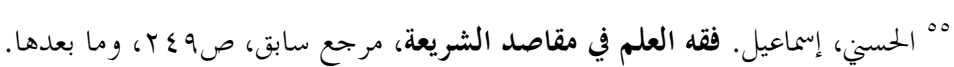

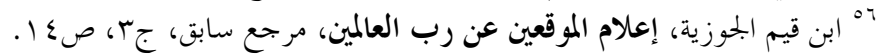

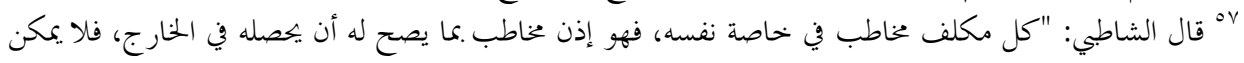

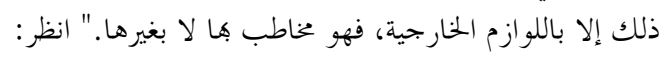

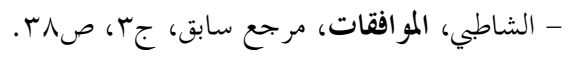




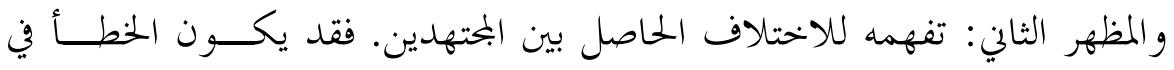

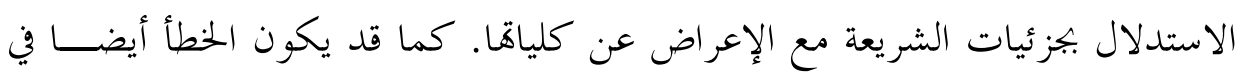

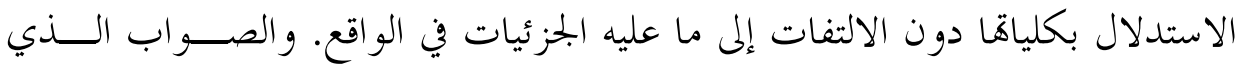

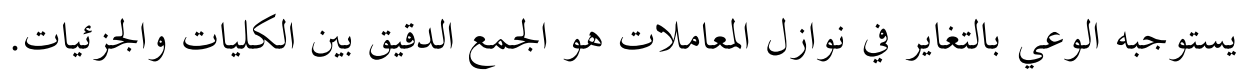

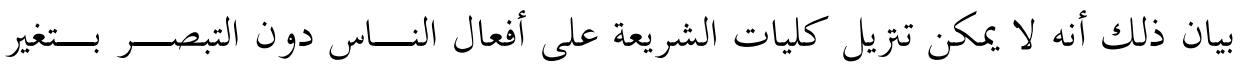

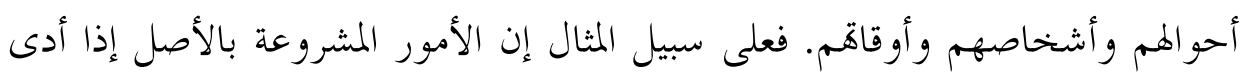

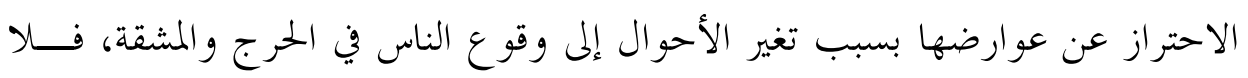

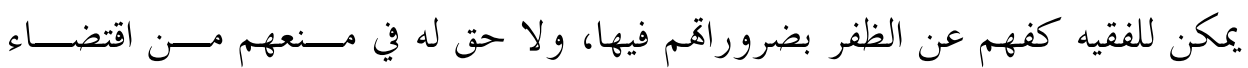

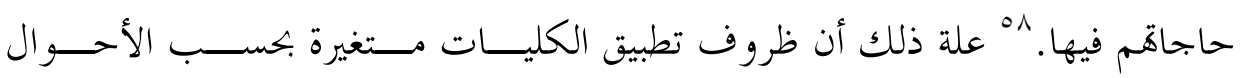

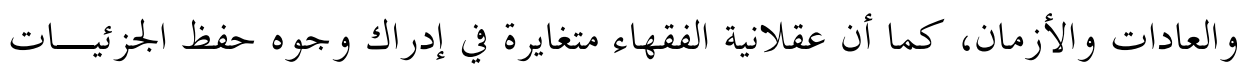

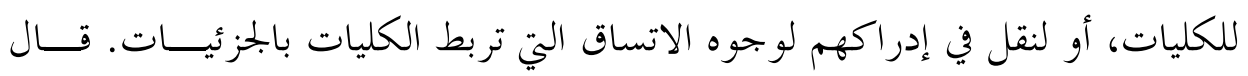

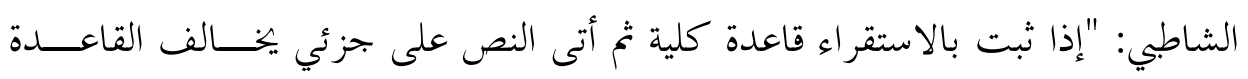

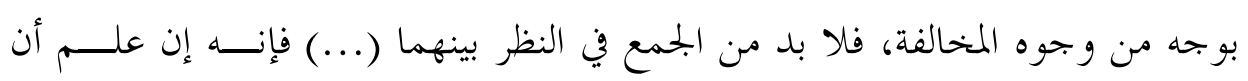

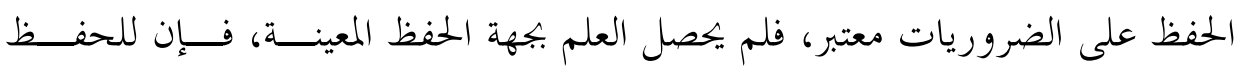

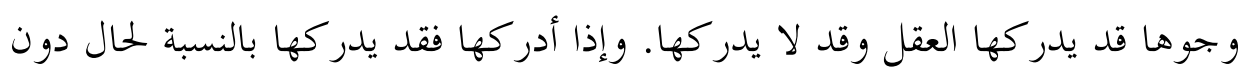

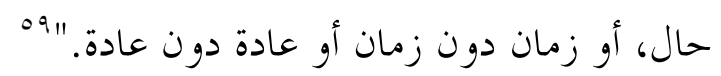

وعلى كل حال إنّ الوعي الدقيق بالتغاير، سبب مفصلي في الالتجـــاء إلى عـــدة

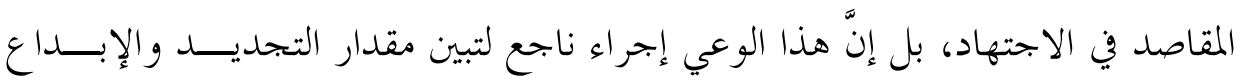

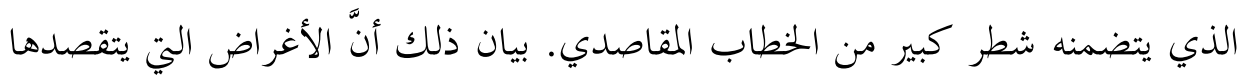

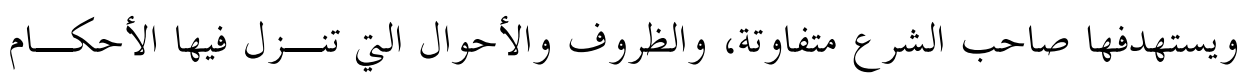

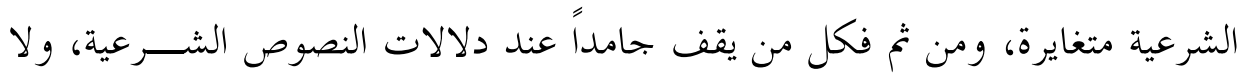

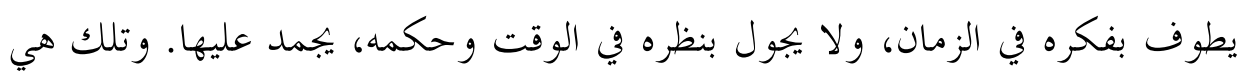

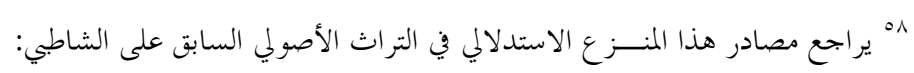

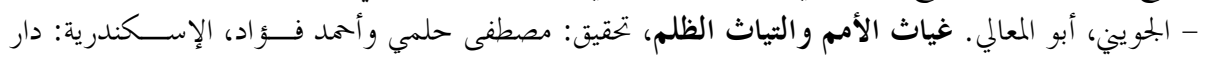

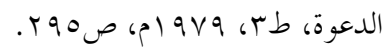

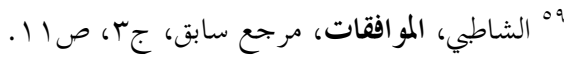


الجناية الحقيقية على الشريعة بتفويت مقاصدها وأغراضها، وبإظهارها في مظهر غــير

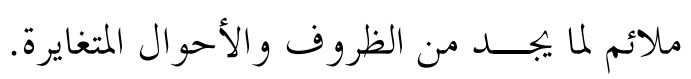

خاتمة:

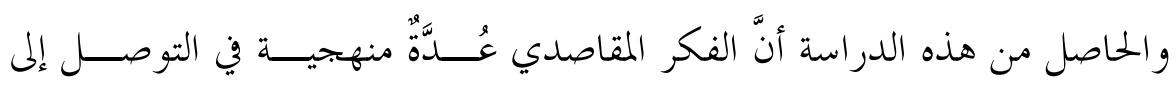

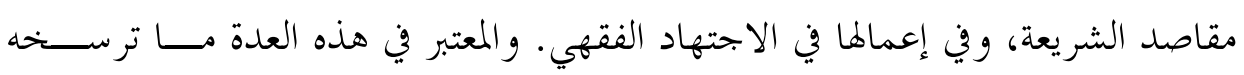
ذهنيا ومنهجيا من فكر علمي في ثلاثة مستويات:

مستوى المبادىی: الذي يجعل الفكر المقاصدي منطلقا دائماً من مبـــادئ الفائـــدة

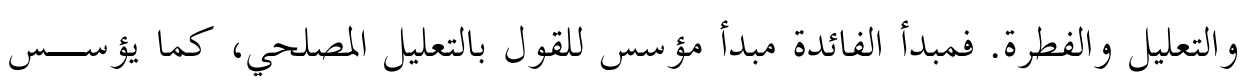

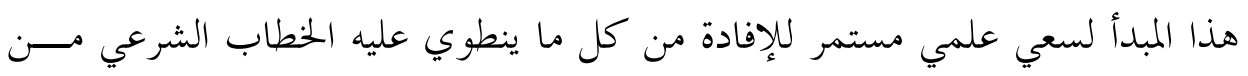

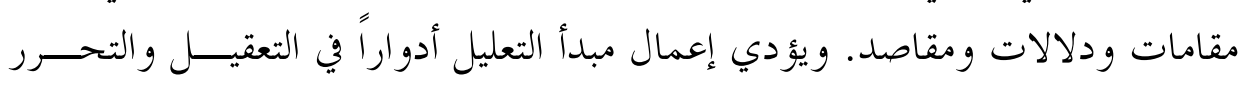

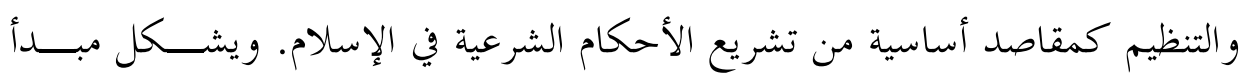
الفطرة مقياساً للمقاصد الشرعية.

ومستوى التقنيات: الذي يجعل هذا الفكر مبنياً دائماً بـــأداتين: أداة استحضـــار

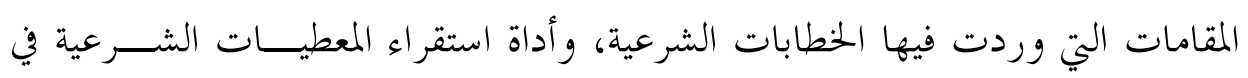

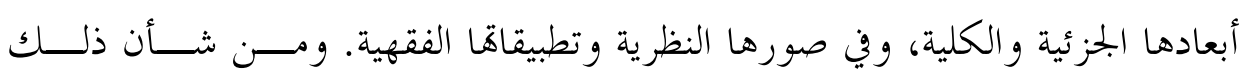

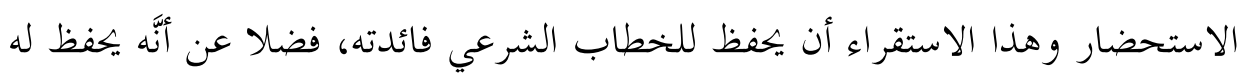
اتساقه الداخلي والخارجي.

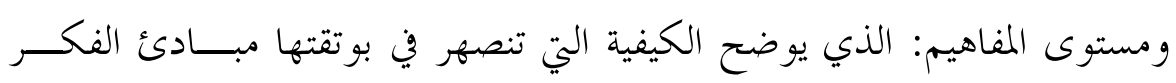

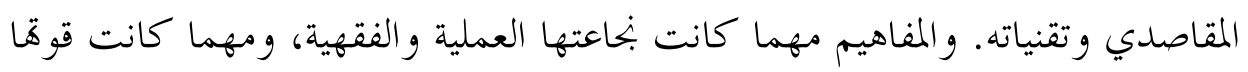

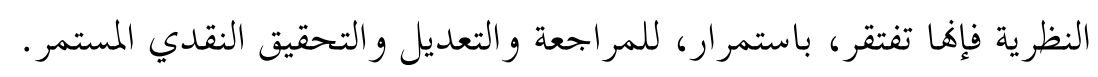
وإذا كان من دروس يمكن للباحث استخلاصها من الفكر العلمي الذي يرســـهـ

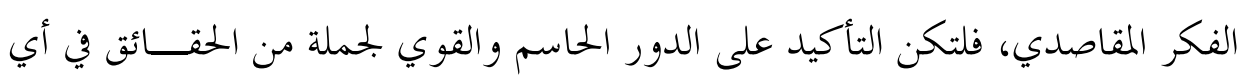

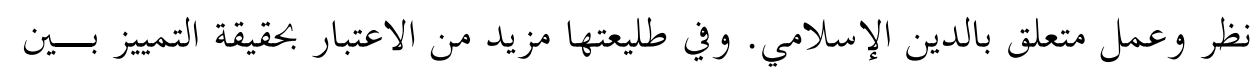


الخاصة و العامة من العلماء بالشريعة. فلا يستقيم التدين هـا في غياب العلم بضوابط فهـــم

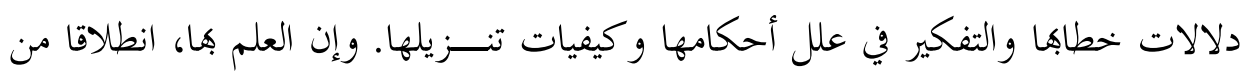
مفهوم التمايز، متفاوت المراتب: مرتبة عامة تتضمن قسم المعلوم من الشريعة بالضـــرورة،

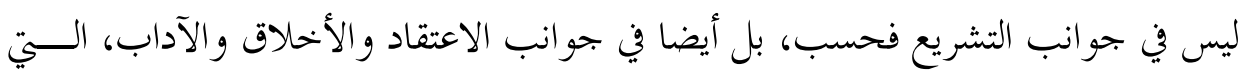

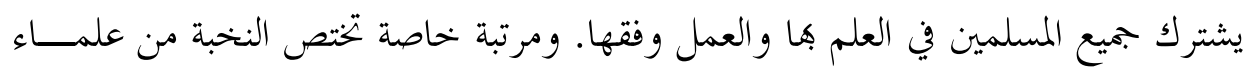

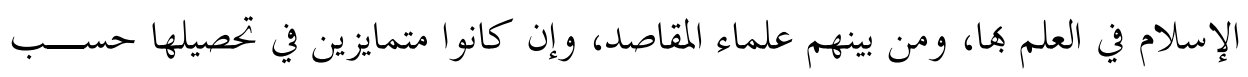
تغاير أعصارهم، وتفاوت إمكانات أفهامهم و استنباطاقم. و الثمرة الأساسية من التمييز بين الخاصَّة والعامَّة، عدم خوض العوام من المســلمين

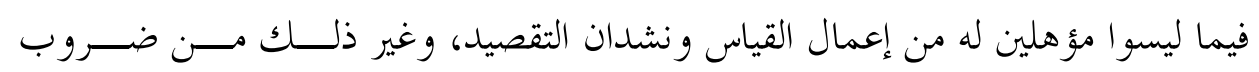

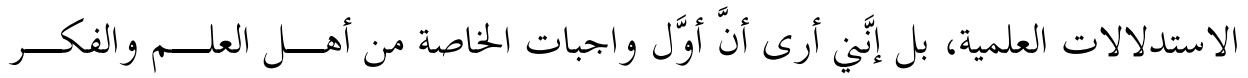

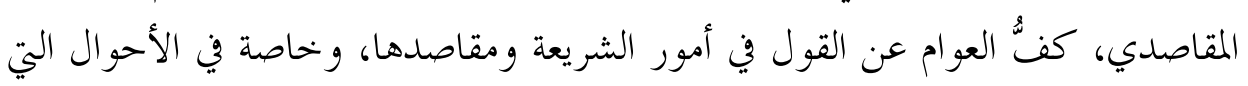
تكون عاجزة عن ذلك، ووي الأحوال التي تخرج عن دائرة مسؤولياتا. و تشكل مفاهيم الفكر المقاصدي روح الاجتهاد في الشريعة. والاجتهاد مقيـــد،

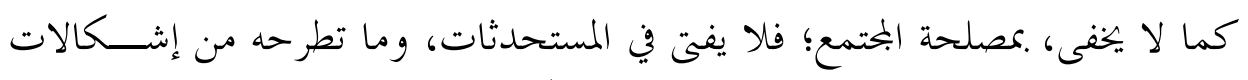

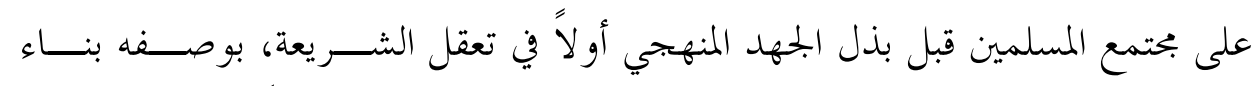

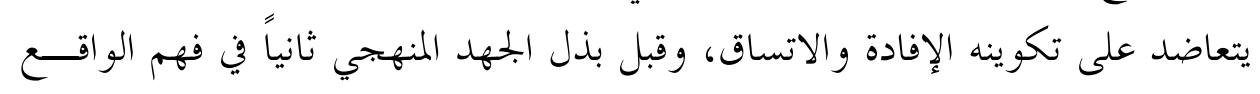
المستجد و المتغير الذي يتوجه عليه خطاهـا المقاصدي. وأهم ما يجبب على وإِلى البحتهد الانتباه

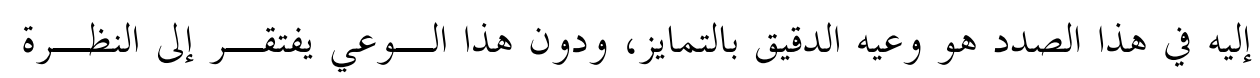

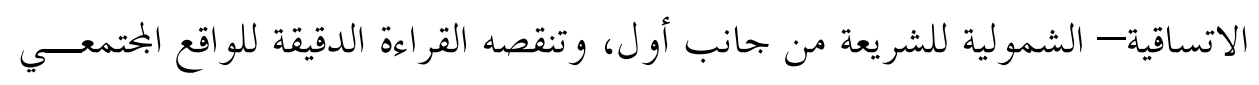

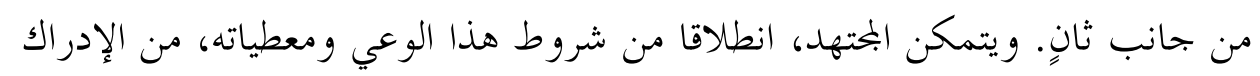

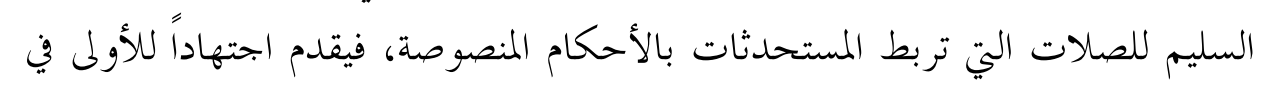
ضوء الثانية، ولثانية في ضوء الأولى.

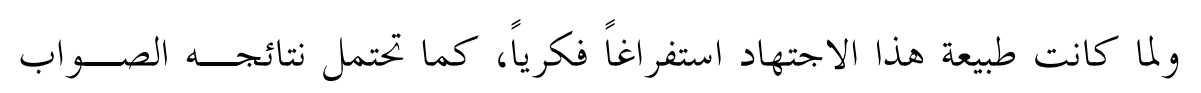

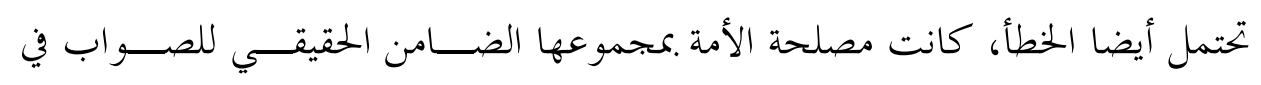




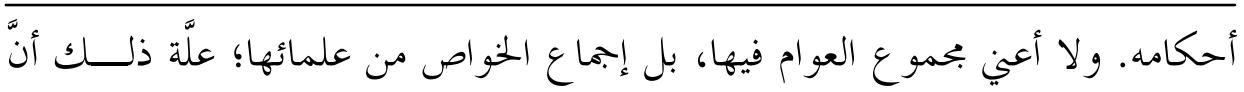

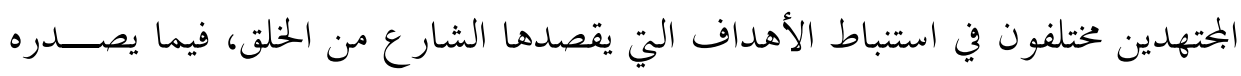
من أوامر ونواهٍ من جهة، وفي تنــزيلها عند الإفتاء في الحوادث المستجدة على الأنظار

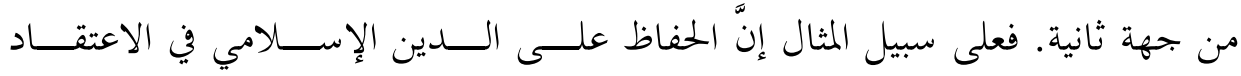

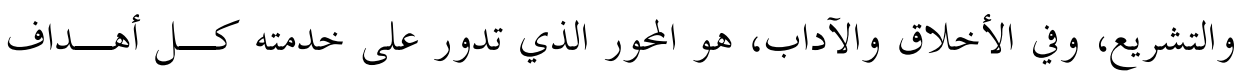

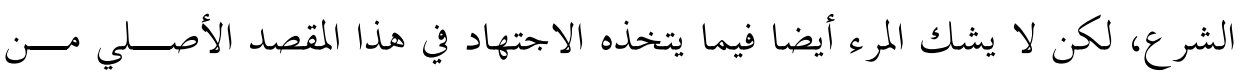

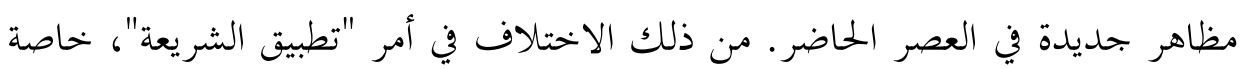

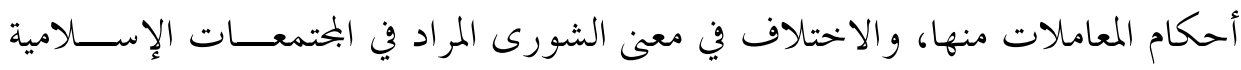
المعاصرة، والاختلاف في تصور الجهاز السياسي الذي يتولى حماية الدين وحفظ بيضة الأمة.

يقود مفهوم التمايز في الفكر المقاصدي إلى حتمية استحضار سعة الأفق، شـــرطاً

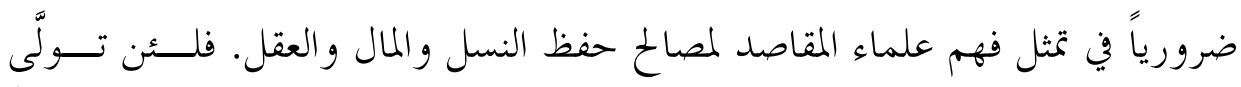

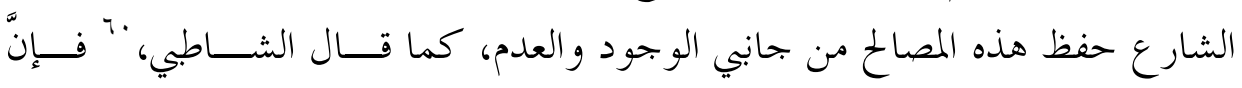
تحديدها في الواقع وتنـزيلها في الوجود الحي يتطلب سعة في آفاق تفكير الفقيه؛ سعة

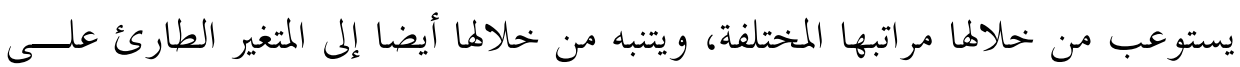

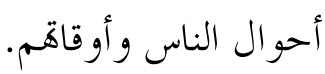

لا يكون حفظ النسل حعصوراً في الأمور المانعة من اختلاط الأنســـاب، بــل إنَّ التمايز النقدي يحملنا على القول بأن المراد من حفظ النسل هو أيضا اجتهاد في الحفاظ

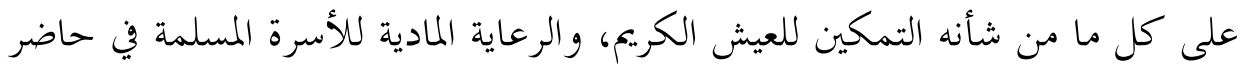

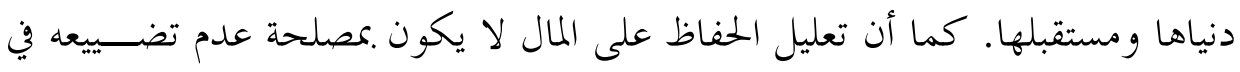

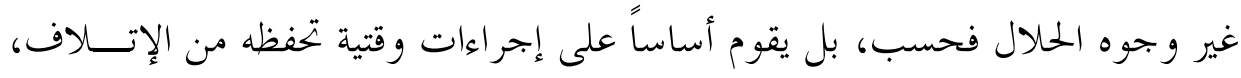

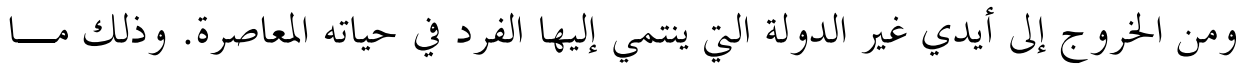

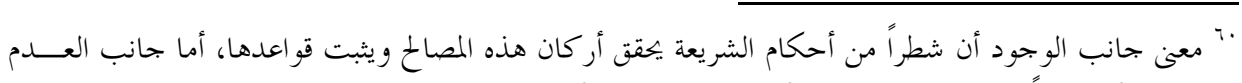

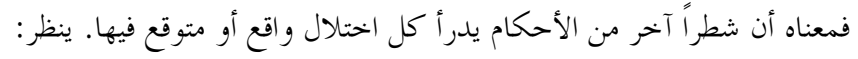

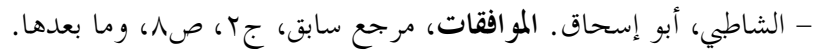




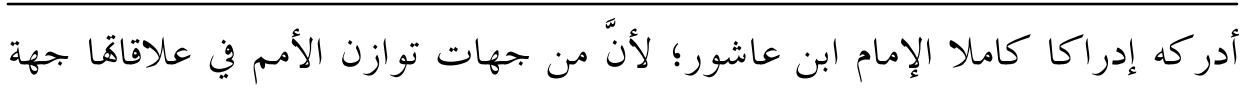

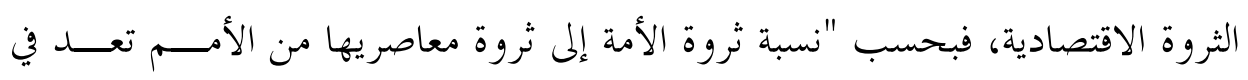

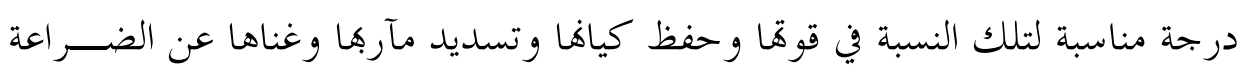

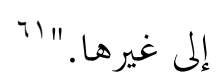

و الحفاظ على سلامة العقل لأنَّه مناط التكليف بأحكام الشريعة، أمر لا ينـــض وحده في تفسير المقصد الشرعي من الحفاظ على العقل بوصفه ضرورة من الضرورات الخمس التي تستهدفها الشريعة. و إن الذي ينهض على هذا التفسير، خاصة في عصرنا

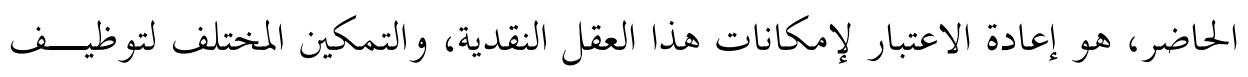
إبداعاته، سواء عند التفكير في إشكالات البحتمع أو عند التفقه في مقاصد الشريعة. تلك وجهة من النظر في ما يرسخه الفكر المقاصدي من فكر علمي عند الــتفكير في شريعتنا الإسلامية، وهي وجهة تفتقر إلى دراسات تطبيقة تخرج البحث في مقاصد الشريعة من دوائر الجحل النظري إلى حيِّر الإنتاجية العلمية و النجاعة العملية. 